\title{
Caroline Ykuta
}

\section{Cadeias produtivas da pesca artesanal marinha: uma investigação comparativa na região costeira do Estado de São Paulo.}

Dissertação apresentada ao Instituto Oceanográfico da Universidade de São Paulo, como parte dos requisitos para obtenção do título de Mestre em Ciências, Programa de Oceanografia, área de Oceanografia Biológica.

Orientadora: Profa. Dra. Maria de los Angeles Gasalla 
Universidade de São Paulo

Instituto Oceanográfico

Cadeias produtivas da pesca artesanal marinha: uma investigação comparativa na região costeira do Estado de São Paulo.

\section{CAROLINE YKUTA}

Dissertação apresentada ao Instituto Oceanográfico da Universidade de São Paulo, como parte dos requisitos para obtenção do título de Mestre em Ciências, Programa de Oceanografia, área de Oceanografia Biológica.

Julgada em ______ por

$\operatorname{Prof}(\mathrm{a}) . \operatorname{Dr}(\mathrm{a})$

Conceito

Prof(a). Dr(a)

Conceito

Prof(a). Dr(a)

Conceito 
A princípio você nada percebe de diferente... A princípio você senta lá e eu aquí Depois, a gente vaíficando cada vez mais perto... ("O Pequeno Principe", Antoine de Saint-Exapéry) 
Dedico esse trabalho

a quem nunca,

nem por um instante,

duvidou das minhas decisões, $e$ me apoiou e apoia incondicionalmente.

A mulher da minha vida, Mamusca. 


\section{AGRADECIMENTOS}

À Profa. Dra. Maria de los Angeles Gasalla, pela orientação, incentivo, ensinamentos em todos os momentos, e principalmente pela confiança no meu trabalho.

Ao CNPq pela bolsa durante o período do mestrado, e do Programa de Pós Graduação em Oceanografia, do Instituto Oceanográfico da Universidade de São Paulo (IOUSP).

Aos pesquisadores do projeto de pesquisa "Avaliação da viabilidade socioeconômica das frotas pesqueiras comerciais que atuam na região Sudeste e Sul do Brasil por meio de indicadores de desempenho" ( $\mathrm{CNPq} \mathrm{N}^{\circ}$ 42/2012) pelo apoio para realizar viagens de campo.

Aos diversos colaboradores do IOUSP, Secretaria de Pós-graduação, biblioteca, xérox e diagramação, informática, técnicos de laboratórios e das bases de pesquisa. Muita gratidão.

Aos amigos do Laboratório de Ecossistemas Pesqueiros (LabPesq), Amanda, Vanessa, Alina, Marília, Aurélia, e em especial ao Ivan pelas grandes discussões sobre fazer ciência, e ao Felippe, grande companheiro.

Ao Programa de Aperfeiçoamento de Ensino (PAE), pela oportunidade de aprimorar minha formação para a atividade didática de graduação. Nesse sentido, agradeço aos professores Maria de los Angeles Gasalla, June Ferraz Dias, Luz Amelia Vega Pérez, Mário Katsuragawa e Paulo Yukio Gomes Sumida, em suas disciplinas para graduação.

À rede internacional "Too Big to Ignore: global partnership for small-scale fisheries research”, coordenação regional para a América Latina e Caribe, que apoiou com suporte financeiro a minha participação no $2^{\text {nd }}$ World Small-Scale Fisheries Congress, em Mérida/México.

Às minhas amigas Camilinha, Maria e Andressa pelas incontáveis conversas sobre o ser, estar, alcançar, sonhar, viver, querer, não querer, continuar, seguir, parar.... cá estamos.

À minha família, Mamusca, Nini, Doug, Papis, Lelê, Mi e Dá, alicerces da minha vida.

E por fim, mas incrivelmente essenciais.... a todos os atores das cadeias produtivas que contribuíram para esse trabalho, sejam pescadores, armadores, processadores, atacadistas e varejistas.... muitos bons corações eu conheci... 


\section{SUMÁRIO}

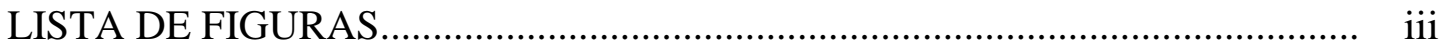

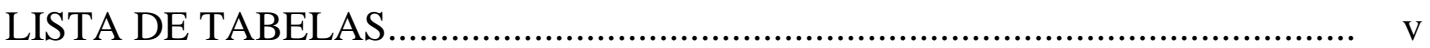

LISTA DE QUADROS.................................................................... vi

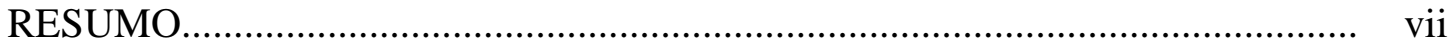

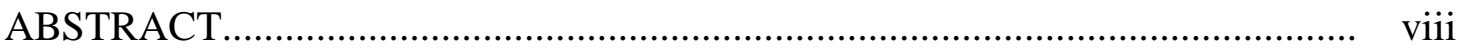

1. INTRODUÇÃ

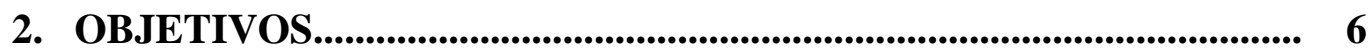

3. MATERIAL E MÉTODOS...................................................................... 7

3.1 Seleção dos sistemas pesqueiros e a área de estudo.............................. 7

3.2 Inquérito para obtenção dos dados..................................................... 9

3.3 Análise das estruturas das cadeias produtivas..................................... 18

3.4 Análise das estruturas das cadeias de valor....................................... 18

3.5 Análise do desempenho das cadeias................................................... 19

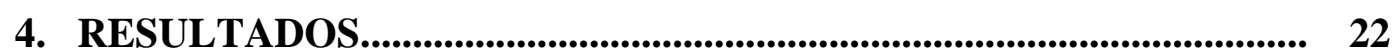

4.1 Sistema pesqueiro da corvina - frota de emalhe com redes de espera de fundo, em Ubatuba (SP)............................................................. 22

4.1.1 Estrutura e função da cadeia produtiva..................................... 22

4.1.2 Estrutura da cadeia de valor....................................................... 27

4.2 Sistema pesqueiro do camarão sete-barbas - frota de arrasto duplo de fundo no Rio do Meio, Guarujá (SP)............................................... 28

4.2.1 Estrutura e função da cadeia produtiva...................................... 28

4.2.2 Estrutura da cadeia de valor................................................... 32

4.3 Sistema pesqueiro da manjuba - canoas com redes de arrasto na Barragem do Valo Grande, Iguape (SP)........................................... 33

4.3.1 Estrutura e função da cadeia produtiva...................................... 33

4.3.2 Estrutura da cadeia de valor.................................................. 40

4.4 Análise comparativa da estrutura, função e das cadeias produtivas e $\quad 41$ 
de valores.

4.5 Desempenho das cadeias de valores.................................................. 44

4.5.1 Equidade.............................................................................. 44

4.5.2 Eficiência............................................................................ 53

4.5.3 Empoderamento...................................................................... 62

4.6 Análise comparativa dos desempenhos das cadeias.......................... 66

5. DISCUSSÃO

5.1 Estrutura e função das cadeias produtivas e das cadeias de valores...... 68

5.2 Desempenho das cadeias produtivas.............................................. 71

5.2.1 Distribuição dos benefícios........................................................ 71

5.2.2 Programas federais e infraestruturas das cadeias produtivas...... 74

5.2.3 Deficiências e entraves nas cadeias produtivas e medidas de regulamentação e ordenamento da pesca.................................. 76

5.2.4 Valor médio das pescarias e do valor agregado ao produto........ 78

5.2.5 Participação da mulher na cadeia produtiva................................ 79

5.2.6 Relações de trabalho e organizações representativas na cadeia produtiva......................................................................... 81

5.2.7 Atravessadores e decisão para comercialização ao longo da cadeia produtiva.................................................................. 83

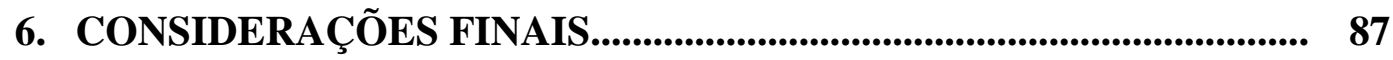

7. CONCLUSÕES................................................................................ 88

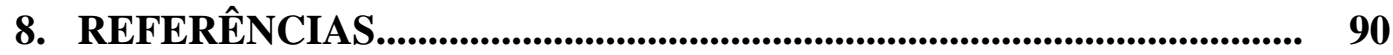




\section{LISTA DAS FIGURAS}

Figura 1 - Segmentos, elos, atores e fluxo do produto da cadeia produtiva de um recurso pesqueiro....................................................................... 2

Figura 2 - $\quad$ Cadeia produtiva da pesca artesanal.................................................. 3

Figura 3 - Mapa do litoral do Estado de São Paulo indicando a localização dos três municípios Ubatuba, Guarujá e Iguape

Figura 4 - Segmentos, elos e atores da cadeia produtiva da corvina.....

Figura 5 - Cadeia produtiva detalhada da corvina desembarcada em Ubatuba, através das embarcações de emalhe de fundo

Figura 6 - Embarcações de rede de emalhe de fundo para captura da corvina, região de Ubatuba (SP).

Figura 7 - Desembarque de corvinas no Cais do Alemão. Presença da equipe do atravessador PK

Figura 8 - Corvinas colocadas à venda nos estabelecimentos varejistas, em Ubatuba (SP) e Rio de Janeiro (RJ).

Figura 9 - Fluxos de produção discriminados pela ordem de importância na cadeia produtiva da corvina.

Figura 10 - Cadeia de valor da corvina, capturada por embarcações de redes de emalhe de fundo e desembarcada em Ubatuba, comercializada inteira/resfriada, 3 fluxos de comercialização, e os preços de comercialização de cada elo.

Figura 11 - Segmentos, elos e atores da cadeia produtiva do camarão sete-barbas...

Figura 12 - Cadeia produtiva detalha do camarão sete-barbas capturado pelas embarcações de arrasto duplo de portas de fundo, e desembarcado no Rio do Meio, Guarujá (SP)

Figura 13 - Embarcações de redes de arrastos duplo e locais de desembarque no Rio do Meio, Guarujá (SP).

Figura 14 - Descabeçadeiras - mulheres que trabalham diretamente no processo de beneficiamento do camarão sete-barbas, nas plantas de processamento do Rio do Meio, Guarujá (SP).

Figura 15 - Estabelecimentos varejistas de comercialização do camarão setebarbas, no Guarujá (SP).

Figura 16 - Fluxos de produção discriminados pela ordem de importância na cadeia produtiva do camarão sete-barbas.

Figura 17 - Cadeia de valor do camarão sete-barbas descabeçado, com dois fluxos de comercialização principais, e os preços de comercialização de cada segmento.

Figura 18 - Cadeia de valor do camarão sete-barbas limpo, três fluxos de comercialização principais, e os preços de comercialização de cada segmento.

Figura 19 - Segmentos, elos e atores da cadeia produtiva da manjuba. 
Figura 20 - Cadeia produtiva detalhada da manjuba desembarcada na prainha da Barragem do Valo Grande, Iguape (SP), através das canoas com rede de arrasto (manjubeira).

Figura 21 - Embarcações canoas com rede de arrasto para captura da manjuba, região da Barragem do Valo Grande, Iguape (SP).

Figura 22 - Desembarque de manjubas na prainha doa Barragem do Valo Grande, Iguape (SP).

Figura 23 - Infraestrutura dos atores envolvidos na cadeia produtiva da manjuba: donos de materiais, atravessadores e plantas de processamento, em Iguape (SP)....

Figura 24 - Estabelecimentos atacadistas no CEAGESP, Vila Leopoldina, São Paulo (SP).

Figura 25 - Fluxos de produção discriminados pela ordem de importância na cadeia produtiva da manjuba.

Figura 26 - Cadeia de valor da manjuba inteira/resfriada desembarcada na prainha da Barragem do Valo Grande, Iguape (SP), quatro fluxos de comercialização principais, e os preços de comercialização de cada segmento.

Figura 27 - Cadeia de valor da manjuba beneficiada (salgada* e eviscerada**) desembarcada na prainha da Barragem do Valo Grande, Iguape (SP), através das canoas com rede de arrasto (manjubeira), e os preços de comercialização de cada segmento.

Figura 28 - Comparação dos fluxos de distribuição principais de cada uma das três cadeias produtivas. 1) corvina; 2) camarão sete-barbas; 3) manjuba......

Figura 29 - Diagrama de distribuição dos benefícios acumulados ao longo da cadeia de valor da corvina inteira e resfriada, referente aos fluxos principal, secundário e terciário.

Figura 30 - Diagrama de distribuição dos benefícios acumulados ao longo da cadeia de valor do camarão sete-barbas descabeçado, referente aos fluxos principal e secundário.

Figura 31 - Diagrama de distribuição dos benefícios acumulados ao longo da cadeia de valor do camarão sete-barbas limpo, referente aos fluxos principal, secundário e terciário.

Figura 32 - Diagramas de distribuição dos benefícios ao longo da cadeia de valor da manjuba inteira/resfriada, referente aos fluxos principal, secundário, terciário e quaternário.

Figura 33 - Diagramas de distribuição dos benefícios acumulados ao longo da cadeia de valor da manjuba salgada e da manjuba eviscerada, referente ao fluxo principal

Figura 34 - Comparação dos diagramas de distribuição dos benefícios ao longo da cadeia de valor da corvina inteira/fresca, do camarão sete-barbas limpo e da manjuba inteira/fresca. 


\section{LISTA DAS TABELAS}

Tabela 1 - Número de atores nos diversos segmentos das cadeias produtivas e proveniência dos consumidores dos sistemas pesqueiros estudados......

Tabela 2 - Produção processada por cadeia produtiva.

Tabela 3 - Margem de comercialização total, em valores em $\mathrm{R} \$$ e valores absolutos, e segmentos que definem o preço da primeira comercialização.

Tabela 4 - Desempenho da proporção do valor de comercialização de cada segmento comparado ao valor final de venda.

Tabela 5 - Desempenho dos programas federais implementados nas cadeias de valores.

Tabela 6 - Valor mediano das pescarias no período da safra de 2013.

Tabela 8 - Comparação dos preços de comercialização no varejo dos recursos processados.

Tabela 9 - Deficiências e entraves levantados pelos representantes (atores da cadeia de valor) e o número de citações de cada item.

Tabela 10 - Desempenho das organizações representativas por segmentos das cadeias de valores.

Tabela 11 - Desempenho da dependência do pescador ao atravessador.

Tabela 12 - Desempenho da ocorrência dos produtores e intermediários no poder de decisão da comercialização do pescado. 


\section{LISTA DOS QUADROS}

Quadro 1 - Número de entrevistas realizadas por local, ponto de coleta e etapa de estudo.

Quadro 2 - Programas públicos federais sobre os quais foram indagados os atores entrevistados, seus objetivos e vigência.

Quadro 3 - Deficiências e entraves............................................................... 15

Quadro 4 - Sumário dos critérios de desempenho, parâmetros indicativos, elementos avaliados, e medidas de avaliação.

Quadro 5 - Desempenho da participação do gênero feminino em cada cadeia de valor estudada.

Quadro 6 - Desempenho da infraestruturas de armazenamento, distribuição e comercialização existentes nos segmentos da cadeia de valor...............

Quadro 7 - Desempenho do número de segmentos que agregam valor ao produto através do beneficiamento.

Quadro 8 - Desempenho das regulamentações e ordenamento aplicados ao

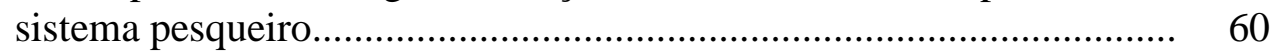

Quadro 9 - Relação de trabalho nos atores identificados nas cadeias de valores..... 64

Quadro 10 - Desempenho das três cadeias produtivas............................................. 66 


\section{RESUMO}

Atualmente, a pesca de pequena escala enfrenta diversas dificuldades, dentre as quais se destacam as deficiências estruturais de armazenamento, conservação e processamento do pescado, mas também dos processos de distribuição e comercialização. Uma das principais necessidades de conhecimento consiste no mapeamento e compreensão dos processos e elos das cadeias produtivas das pescarias artesanais. O objetivo desse estudo foi tecer uma investigação comparativa focada na estrutura, função, e desempenho das cadeias produtivas de três sistemas pesqueiros do Estado de São Paulo com significância socioeconômica: o da corvina (Micropogonias furnieri) capturada por redes de emalhe em Ubatuba; o do camarão sete-barbas (Xiphopeneaus kroyeri) capturado por redes de arrasto, no Rio do Meio, Guarujá; e o da manjuba (Anchoviella lepidentostole) capturada por redes de emalhe na Barragem do Valo Grande, em Iguape. Os dados de campo foram coletados durante o período de março/2013 a janeiro/2015 por meio de questionários aplicados em entrevistas com os atores envolvidos nos processos de captura, processamento, distribuição e comercialização do pescado. A cadeia produtiva da manjuba se mostrou como a mais complexa do grupo, com maior número de atores e fluxos de distribuição, alta abrangência de distribuição e diferentes tipos de processamento. Quanto à distribuição dos benefícios, a maior margem de comercialização foi verificada na planta de processamento da cadeia do camarão, enquanto que a menor foi a dos atravessadores das cadeias da corvina e da manjuba. $\mathrm{O}$ produto final com maior valor de comercialização no varejo foi a da manjuba eviscerada (7,6 vezes maior que o valor de primeira comercialização). Em relação ao desempenho das cadeias estudadas, os indicadores de equidade, eficiência, e empoderamento apresentaram baixa adesão, sugerindo uma necessidade de melhorias em todos os segmentos. A partir dos métodos e resultados deste estudo, tópicos importantes sobre as cadeias produtivas e de valores da pesca de pequena escala, poderão servir de base para a definição de políticas de gestão mais eficientes visando a sustentabilidade do setor, ou ainda, para a melhoria da qualidade do pescado e dos segmentos envolvidos nessas atividades.

Palavras chaves: pesca artesanal, cadeia produtiva, cadeia de valor, distribuição dos benefícios, indicadores de desempenho, empoderamento, eficiência, equidade, corvina, camarão sete-barbas e manjuba. 


\section{ABSTRACT}

Currently, small-scale fisheries face several difficulties, such as structural deficiencies for fish storage and preservation, but also in the process of distribution and marketing. One of the main knowledge gap is the mapping and understanding of the processes and links of the small-scale fisheries value chains. In this study, a comparative investigation focused on the structure, function and performance of supply chains from three fishery systems with significative socioeconomic relevance in São Paulo State was performed. The systems comprise the whitemouth croaker (Micropogonias furnieri) fishery by gillnetters in Ubatuba, the seabob-shrimp (Xiphopeneaus kroyeri) fishery by Rio do Meio's trawlers in Guarujá, and the broadband anchovy (Anchoviella lepidentostole) fishery by canoes with gillnets in the Valo Grande Dam, in Iguape. The data were collected at field from March/2013 to January/2015 through questionnaires and inperson surveys with the actors involved in the processes of catch, processing, distribution and sale. The supply chain of broadband anchovy proved to be the most complex, with highest number of actors and distribution flows, high range of distribution and different processing forms. On the distribution of benefits, the highest marketing margin was verified in the processing plant of the seabob-shrimp's chain, while the lowest, was identified in the middlemen of croaker and anchovy chains. The final product with largest retail sale value was the eviscerated broadband anchovy (about 7.6 times higher than the first sale value). In regard to equity, efficiency and empowerment criteria on value chains performance, the three fishery systems showed low compliance in all considered indicators, suggesting a need for improvements in all segments. This study obtained relevant details on the supply and value chain of the three small-scale fisheries of São Paulo. These data and the methods proposed may support the definition of management policies more efficient for the sector's sustainability, in addition, to improve the quality of fish and human segments involved in these activities.

Keywords: small-scale fishery, supply chain, value chain, distribution of benefits, performance indicators, empowerment, efficiency, equity, whitemouth croaker, seabobshrimp and broadband anchovy. 


\section{INTRODUÇÃO}

Globalmente, mais de 54 milhões de pessoas estão envolvidas na atividade de pesca e aquicultura, e cerca de três vezes mais participam de atividades relacionadas aos processos de pré e pós-captura, como por exemplo, na construção de barcos, no processamento e na comercialização do pescado (BJORNDAL et al., 2014). Estima-se que a pesca de pequena escala emprega $90 \%$ dos pescadores de todo o mundo e é responsável por cera de $50 \%$ da produção mundial de peixes (United Nations General Assembly, 2012). No Brasil, a pesca artesanal possui grande importância social e econômica, e é responsável por mais de $50 \%$ de toda a produção pesqueira nacional, podendo chegar a 70\% em algumas áreas como o norte do país (DIEGUES, 1995; VASCONCELLOS et al., 2007; BEGOSSI, 2010).

No Estado de São Paulo, algumas pescarias importantes para o mercado consumidor nacional são realizadas em pequena escala, em águas litorâneas e interiores, com embarcações geralmente de pequeno porte e equipamentos de tecnologia simples (DIEGUES, 1983; 2008). Destacam-se, por exemplo, a pesca da corvina (Micropogonias furnieri), a do camarão sete-barbas (Xiphopenaeus kroyeri) e a da manjuba (Anchoviella lepidentostole), os quais encontram-se entre as oito categorias de pescado mais capturadas nos últimos anos (IP, 2013).

De modo geral, a sustentabilidade da pesca de pequena escala no Brasil enfrenta diversas dificuldades, dentre as quais, queda nos rendimentos e deficiências estruturais no armazenamento, na conservação do pescado, na distribuição e também na comercialização. Além disso, em comparação à pesca industrial, o pescador artesanal dispõe de menos recursos materiais para a captura, o transporte, o armazenamento e o comércio da produção (DIEGUES, 1983; CASTRO et al., 2005; BEGOSSI, 2006). Do ponto de vista do conhecimento necessário para promover melhorias, nesse sentido, uma das principais lacunas é a obtenção de informações e análises regulares especificamente sobre as cadeias produtivas e as cadeias de valores (EMBRAPA, 2012; TBTI, 2013).

A atividade pesqueira abrange processos desde a captura até a venda do pescado para a indústria, ou diretamente ao consumidor (ABDALLAH, 1998). A cadeia produtiva da pesca é uma rede de atores de negócios ou de atividades relacionados com um produto, pelo qual se move desde o ponto da produção até o consumo, incluindo a 
pré-produção e as atividades pós-captura, e na qual, a produção é dependente de uma logística eficiente, sendo que a principal preocupação nesse sentido são os custos e o tempo que leva para o produto chegar até a venda (De SILVA, 2011). As medidas tomadas por um dos atores da cadeia podem afetar positivamente ou negativamente toda uma cadeia produtiva (THORPE e BENNETT, 2004; UNEP, 2009).

A cadeia produtiva de recursos pesqueiros pode ser descrita, de modo geral, como uma interação dos insumos e segmentos, elos e atores, compostos por: pescadores interdependentes; intermediários que trabalham em conjunto para fornecer um produto ao consumidor por meio da transformação ou da distribuição, tais como processadores, beneficiadores, distribuidores, atacadistas e/ou varejistas; e os próprios consumidores (Figura 1). As atividades e processos dos atores são influenciados principalmente pelos ambientes institucionais (leis, normas, instituições normativas) e organizacionais (instituições de governo e de crédito) (CASTRO et al., 1995; GIULIETTI et al., 1996; THORPE e BENNETT, 2004; SILVA, 2005).

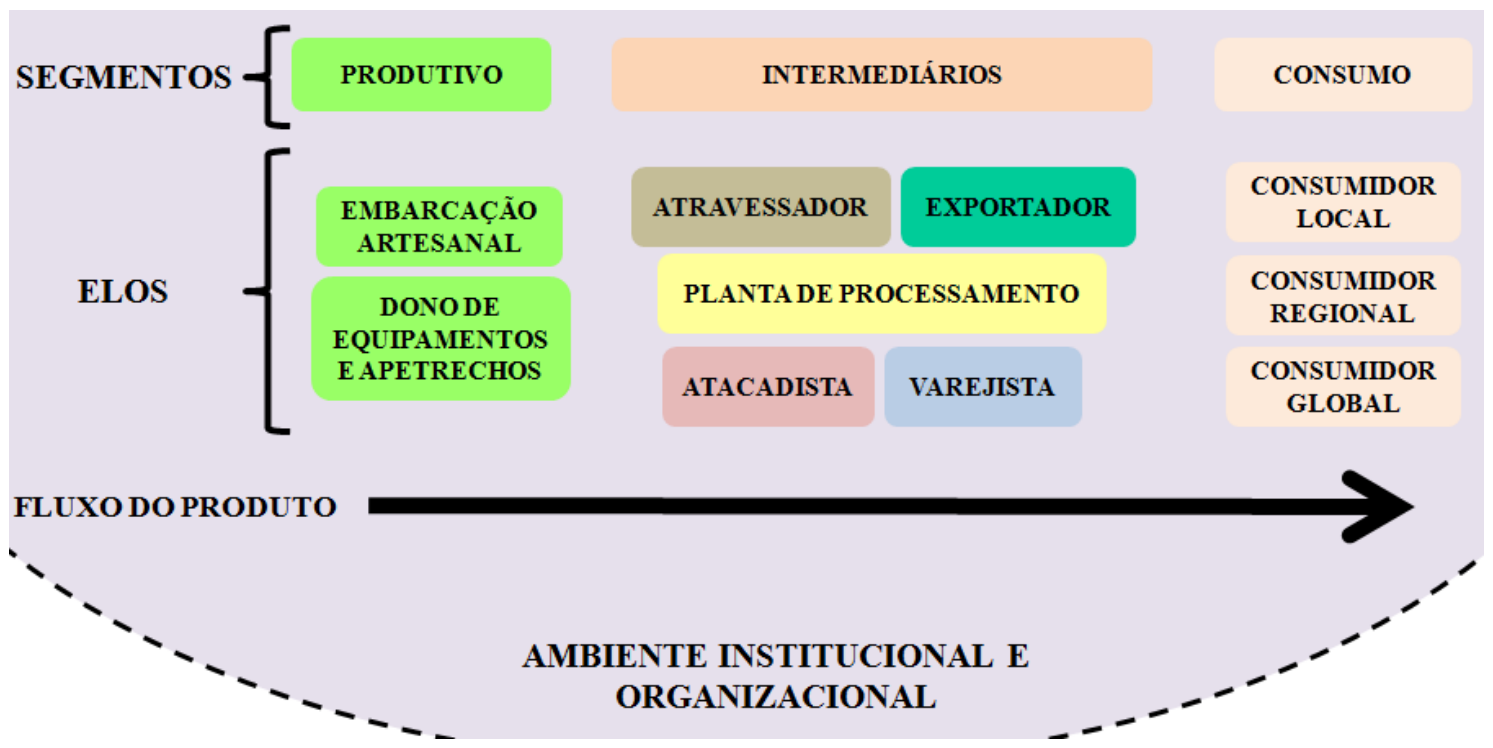

Figura 1 - Segmentos, elos, e fluxo do produto na cadeia produtiva de um recurso pesqueiro (Adaptado de CASTRO et al., 1995 e GIULIETTI et al., 1996).

A cadeia produtiva da pesca artesanal é comumente representada pelos atores: embarcação artesanal, atravessador, planta de processamento, atacadista, varejista, e consumidor regional, e o fluxo de comercialização do recurso pesqueiro, ao longo da cadeia, é usualmente via segmentos: produtivo $\rightarrow$ intermediários $\rightarrow$ consumo, conforme apresentado na Figura 2. 
Figura 2 - Cadeia produtiva da pesca artesanal (Adaptado de THORPE e BENNETT, 2004).

Existem diferenças nas cadeias de produção de recursos pesqueiros entre os países e regiões, correspondendo às condições ambientais, sócio-econômicas e culturais, além das diferenças em relação às espécies de pescado e seus produtos, bem como nas técnicas de captura (UNEP, 2009). Além de possuírem características específicas, distintas de outras cadeias alimentícias, tais como alta perecibilidade e dependência da natureza, sazonalidade, necessidade de transporte especial e condição de armazenamento, há questões de segurança alimentar do produto. Estas características parecem afetar o desempenho da cadeia produtiva pesqueira, sendo assim necessário um sistema específico de medição de seu desempenho (WINDYANINGRUN e MASTRUROH, 2012).

Para tanto, o conhecimento organizado e um mapeamento sobre os fornecedores de insumos (equipamento para pesca, redes, barcos, combustível), os produtores (pescadores e donos de apetrecho), os intermediários (atravessadores, processadores, atacadista e varejistas) e os consumidores (local, regional e nacional) permite definir orientações visando melhorar a valorização e sustentabilidade do pescado, bem como aprimorar os elos entre os processos de captura e comercialização de modo a promover práticas mais sustentáveis nos diversos aspectos ecológicos, sociais, e econômicos.

Nesse sentido, diversos estudos vêm sendo desenvolvidos no Brasil e no mundo, visando caracterizar a cadeia produtiva de pescarias relevantes tais como: MARTIN e MARTINS (1999), CASTRO et al. (2005), SANTOS (2005), ARCHIDIACONO (2007), ROHEIM (2008), MOURÃO et al. (2009), HAMERI e PÁLSSON (2010), LIMA (2010), e CONNOLLY e CAFFREY (2011). Sendo que um dos principais problemas nesse tipo de estudo é a dificuldade de se identificar, quantificar e qualificar todos os elos envolvidos na atividade. 
De modo geral, o principal objetivo da gestão de uma cadeia produtiva é maximizar os lucros através da redução do número de ligações (elos da cadeia) e o atrito entre eles, como gargalos, custos, tempo de mercado, etc. Portanto, um ponto crucial no estudo da cadeia produtiva da pesca é a análise da distribuição de benefícios ao longo da sua cadeia de valores, ou seja, compreender como o valor é somado à medida que o produto avança entre os elos até o consumidor final (KAPLINSKY e MORRIS, 2000; De SILVA, 2011; RUSSEL e HANOOMANJEE, 2012).

Por outro lado, uma cadeia de valor pode ser vista como um passo adiante na cadeia produtiva, pois além de trazer o produto para o mercado, visa proporcionar um ambiente mutuamente mais benéfico para todos os atores e segmentos envolvidos, maximizando a receita líquida através da agregação de valor ao produto, quer por adição de valor ou criação de valor (PORTER, 1990; De SILVA, 2011; RUSSEL e HANOOMANJEE, 2012; BJORNDAL et al., 2014).

Diversos estudos analisaram a cadeia de valor da pesca, tais como GUDMUNDSSON et al. (2006), TORIBIO e GUARCÍA-del-HOYO (2006), AHMED (2007), DUBAY et al. (2010), ANTWI-ASARE e ABBEY (2011), ALAN et al. (2012), RUSSEL e HANOOMANJEE (2012), BUTLER et al. (2013) e WAMULOTA et al. (2014), e permitiram observar que a transmissão de preços dos produtos pesqueiros, ao longo dos elos da cadeia de valor, considera as margens de comercialização (margem bruta e margem total). As margens de comercialização possibilitam o acompanhamento da evolução e desempenho das cadeias, bem como do mercado consumidor (MARQUES e AGUIAR, 1993). Sendo assim, uma análise aprofundada da cadeia de valor consiste em identificar os fatores críticos ao desempenho da cadeia, os pontos de estrangulamento e as oportunidades para o seu desenvolvimento, e é realizada a partir da formulação de critérios e indicadores. Os critérios de mensuração mais comuns são: eficiência, qualidade, competitividade, equidade e sustentabilidade ambiental (CASTRO et al., 1999; CASTRO, 2001).

No entanto, quando se pretende verificar a eficiência de toda uma cadeia produtiva, ou sua equidade, esses fatores podem estar mais relacionados com os aspectos das interações entre os segmentos e com a maneira pela qual esses detêm recursos necessários à sobrevivência de outros (LIMA, 2001). Por outro lado, indicadores de desempenho da cadeia de produção pesqueira têm sido mais 
desenvolvidos para a pesca industrial, sendo estes: flexibilidade, receptividade, qualidade do produto, qualidade no processo e envolvimento governamental, ou mesmo através de indicadores econômicos (WINDYANINGRUN e MASTRUROH, 2012; PHAM et al., 2013). Para a pesca de pequena escala, verifica-se uma necessidade de aplicação de indicadores para medir o desempenho da cadeia produtiva com base no contexto econômico, social, ambiental e de governança.

Diante desse panorama, constata-se uma lacuna de informações e análises detalhadas com relação à estrutura, função, e de desempenho para as cadeias produtivas da pesca artesanal, como é o caso das principais pescarias do Estado de São Paulo. Apesar de iniciativas pretéritas em alguns estudos descrevendo relações entre pescadores artesanais e comerciantes, não há informações detalhadas sobre a complexidade desses aspectos. Nesse contexto, o presente estudo propõe uma investigação e avaliação comparativa das cadeias produtivas, para três sistemas pesqueiros artesanais de relevância regional. 


\section{OBJETIVOS}

O objetivo principal do presente estudo é investigar três cadeias produtivas da pesca artesanal do litoral do Estado de São Paulo: a da corvina em Ubatuba (litoral Norte), a do camarão sete-barbas, no Rio do Meio (Guarujá, litoral Centro), e a da manjuba, na Barragem do Valo Grande (Iguape, litoral Sul).

Considerando esses três sistemas de produção pesqueira acima indicados, os objetivos secundários do estudo são:

1. Identificar a estrutura e função das cadeias produtivas, mapeando os diferentes elos e fluxos,

2. Identificar as cadeias de valores dos principais produtos,

3. Avaliar o desempenho dessas cadeias. 


\section{MATERIAL E MÉTODOS}

\subsection{Selecão dos sistemas pesqueiros e a área de estudo}

Foram selecionados três sistemas pesqueiros de pequena escala relevantes com base na análise de dados quantitativos e qualitativos, tais como estatísticas pesqueiras, desembarques, tamanho das frotas, quantidade de pescadores e atores possivelmente envolvidos, locais de desembarque, e importância econômica do pescado na região, informações estas baseadas nos estudos de VALENTINI et al. (1991), VAZZOLER (1991), GIULIETTI (1992), RODRIGUES (1993), SALDANHA (2005), IBAMA (2007), MPA (2010), e IP (2013):

a. Sistema pesqueiro da corvina capturada por barcos de emalhe de fundo e desembarcada em Ubatuba (SP);

b. Sistema pesqueiro do camarão sete-barbas capturado por barcos de arrasto de fundo duplo, e desembarcado no Rio do Meio, Guarujá (SP); e

c. Sistema pesqueiro da manjuba capturada por canoas com redes de emalhe, e desembarcada na Barragem do Valo Grande, Iguape (SP).

A corvina (Micropogonias furnieri, DESMAREST, 1823) apesar de encontrada em todo o litoral do Brasil é mais abundante entre o sul e sudeste, possui hábitos demersais e são encontradas entre 30-50m de profundidade da costa (VAZZOLER, 1971; 1991). Devido a essas características costeiras, o estoque da corvina explorado no sudeste é, em termos de volume, da principal espécie demersal desembarcada pela frota artesanal na região do Brasil, ocupando $2^{\circ}$ lugar entre os peixes costeiros de valor comercial do Estado de São Paulo (CARNEIRO et al., 2005). Apesar de capturada o ano todo, o estoque da corvina no sudeste é mais abundante no inverno, entre os meses de julho e outubro (IP, 2013). Na região de Ubatuba, o estoque é explorado principalmente por embarcações de emalhe de pequeno e médio porte, com redes de espera de fundo (VALENTIN \& PEZZUTO, 2006).

O camarão sete-barbas (Xiphopenaeus kroyeri, HELLER, 1862) também é encontrado ao longo do litoral do país (HOLTHUIS, 1980 apud VALENTINI et al., 1991), no qual o estoque da região sudeste do Brasil é explorado o ano todo, com 
exceção do período de defeso entre março e maio (MMA, 2008), e principalmente, por meio de embarcações de arrasto de fundo duplo (GRAÇA-LOPES et al., 2007), sendo a sua produção intensificada nos meses de junho a setembro (IP, 2013). É a terceira espécie de pescado mais capturada do Estado de São Paulo, apresentando alta relevância econômica e social (ÁVILA-DA-SILVA et. al., 2005). A pesca camaroeira, incluindo a do sete-barbas, constitui uma das mais importantes para a economia pesqueira do Brasil (GRAÇA-LOPES et al., 2007), entretanto sua produção tem flutuado bastante no decorrer dos anos, instabilizando os setores da sociedade ligados diretamente à sua captura (GRAÇA-LOPES et al., 2002). Atualmente, o estoque é considerado em estado estável (MENDONÇA e LUCENA, 2013).

A manjuba (Anchoviella lepidentostole, FOWLER, 1911) é uma espécie anádroma, ou seja, que migra do oceano para as águas de interior para a reprodução (BENDAZOLI e ROSSI-WONGTSCHOWSHI, 1990). O principal estoque pesqueiro da manjuba no Brasil encontra-se na região de Iguape (SP), onde a manjuba sobe o rio do Ribeira de Iguape entre os meses de outubro e março (época de safra do recurso), período que coincide com alta pluviosidade e elevada temperatura na região (ROSSIWONGTSCHOWSKI et al., 1990). Capturada principalmente por embarcações de pequeno porte (botes e canoas), com redes de meia água, chamadas "manjubeiras", é uma pescaria considerada estuarina e possui grande importância econômica no estado de São Paulo, principalmente para o município de Iguape (MENDONÇA, 2007). Mudanças ecológicas tais como a implantação da Barragem no Valo Grande, em 1979, a pesca intensiva na desembocadura do Rio Ribeira, e o assoreamento do leito do rio tornando a profundidade do estuário e do rio mais baixa, não tem favorecido a desova completa desse recurso, representando alguns dos motivos que explicam a diminuição da sua captura no decorrer dos anos (GUIMAS et al., 1987; SALDANHA, 2005).

Os três sistemas pesqueiros estão localizados no litoral do Estado de São Paulo, nas regiões litorâneas Norte (Ubatuba), Centro (Guarujá), e Sul (Iguape), representados na Figura 3. Em 2013, a corvina, o camarão sete-barbas, e a manjuba representaram juntas 30\% da produção total capturada no Estado de São Paulo. Em Ubatuba, a corvina representa atualmente $30 \%$ do pescado desembarcado, já em Santos e Guarujá, o camarão sete-barbas representa 3,2\%, e em Iguape, a manjuba representa 98,2\% do total desembarcado (IP, 2014). 


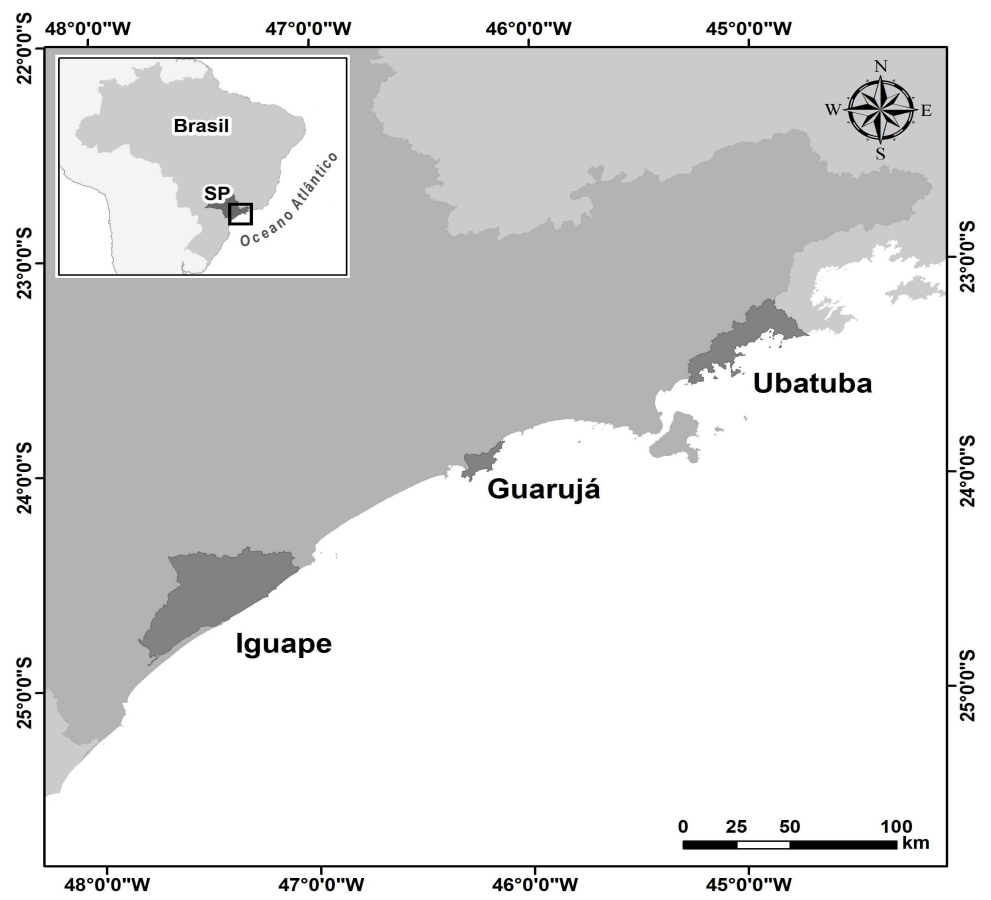

Figura 3 - Mapa do litoral do Estado de São Paulo indicando a localização dos três municípios Ubatuba, Guarujá e Iguape.

\subsection{Inquérito para obtenção dos dados}

Os dados foram obtidos através de entrevistas com os atores envolvidos nas cadeias produtivas dos três sistemas pesqueiros, tais como pescadores artesanais, armadores, donos de apetrechos e embarcações, atravessadores, donos de plantas de processamento, atacadistas e varejistas, e por meio de três diferentes questionários semiestruturados e observações diretas em campo.

Os três questionários foram baseados e adaptados de estudos anteriores, tais como GIULIETTI (1992), MARTIN e MARTINS (1999), SALDANHA (2005), SANTOS (2005), ARCHIDIACONO (2007), BJORNDAL (2010), LIMA (2010), e FAO (2011). O método para aplicação dos questionários consistiu na entrevista pessoal dos atores envolvidos nos processos de captura, produção, beneficiamento, distribuição e venda do pescado. Também foi adotado o método de abordagem "bola de neve" (GASALLA, 2004, SILVANO e BEGOSSI, 2010; LEITE, 2011), no qual o ator entrevistado indica outros atores para serem entrevistados e assim sucessivamente, com o objetivo de atingir um contingente amostral representativo. 
Etapas da coleta:

A coleta de dados foi dividida em duas etapas: 1) aplicação de um primeiro questionário sobre a identificação dos segmentos e dos atores existentes nas cadeias de produção, através de uma abordagem prospectiva; e 2) aplicações de um segundo e terceiro questionários para conhecimento sobre a estrutura, função e distribuição de benefícios, e desempenho das cadeias produtivas.

A primeira etapa foi realizada com representantes de órgãos públicos (Instituto de Pesca, em Ubatuba e Santos), associações de pesca (Colônias de Pescadores em Ubatuba, Guarujá e Iguape) e atores que poderiam estar envolvidos diretamente ou indiretamente na cadeia de valores dos pescados (pescadores e armadores; atravessadores, beneficiadores, atacadistas e varejistas). A segunda etapa foi realizada com todos os atores identificados na etapa anterior, bem como em novos atores que também foram identificados na segunda etapa.

A Quadro 1 sumariza as atividades de coleta de dados realizadas no período de março de 2013 a dezembro de 2014, totalizando 87 dias de campo e um total de 164 entrevistas. A coleta de dados ocorreu no período de safra de cada recurso pesqueiro, sendo assim, dados da corvina foram coletados entre os meses de julho a outubro, dados do camarão sete-barbas foram coletados entre junho a setembro, e dados da manjuba foram coletados entre dezembro a abril, enquanto que as informações dos preços de comercialização dos produtos pesqueiros foram obtidas periodicamente (diário, semanal e quinzena), a fim de determinar a distribuição dos benefícios de forma mais eficaz.

O primeiro questionário inclui informações sobre a atividade do entrevistado, o conhecimento dos fluxos do pescado desde a captura ao consumidor, quais atores estariam envolvidos no processo de compra e venda, e se o pescado era processado e por quem.

Com o segundo questionário obteve-se informações sobre a estrutura e função dos atores identificados, período da pescaria, método e equipamentos de pesca utilizados, tipo de conservação do pescado, locais utilizados para desembarque, para quem era vendido o pescado, como era vendido o pescado, conhecimento de regulamentos ou normas legais sobre o esse pescado, grau de escolaridade do pescador, renda mensal, realização de outra atividade remunerada, tipos de processamento do 
pescado (salgado, seco, enlatado, refrigerado ou congelado), tecnologias utilizadas para o processamento, quantidade de pessoas envolvidas no beneficiamento, como e quem realiza o transporte desses produtos, os locais da venda do produto, se o produto era vendido no mercado nacional ou exportado, os valores do produto vendido ( $\mathrm{R} \$ / \mathrm{kg}$ ), como o pescado é exposto e vendido, e possíveis melhorias na venda e valorização do preço do pescado.

Quadro 1 - Número de entrevistas realizadas por local, ponto de coleta e etapa de estudo. Q1 = questionário 1; Q2 = questionário 2; Q3 = questionário 3.

\begin{tabular}{|c|c|c|c|c|}
\hline \multirow{3}{*}{ Local } & \multirow{3}{*}{ Pontos de coleta } & \multicolumn{3}{|c|}{ Número de entrevistas } \\
\hline & & \multirow{2}{*}{$\begin{array}{c}\begin{array}{c}\text { Etapa } 1 \\
(\mathrm{mar}-\mathrm{jul} / 13)\end{array} \\
\mathrm{Q} 1\end{array}$} & \multicolumn{2}{|c|}{$\begin{array}{c}\text { Etapa } 2 \\
(\text { ago/13 }- \text { dez/14) }\end{array}$} \\
\hline & & & Q2 & Q3 \\
\hline \multirow{6}{*}{ Ubatuba, SP } & Píer do Saco do Ribeira & 4 & 5 & 4 \\
\hline & Instituto de Pesca, Itaguá & 1 & - & - \\
\hline & Píer do Cais do Alemão & 3 & 6 & 5 \\
\hline & Barra dos Pescadores & 3 & 4 & 3 \\
\hline & Praia da Picinguaba & - & 6 & 2 \\
\hline & $\begin{array}{l}\text { Municipal de Peixes e } \\
\text { peixarias ao redor }\end{array}$ & 3 & 4 & 3 \\
\hline Guarujá, SP & $\begin{array}{c}\text { Plantas de processamento } \\
\text { no Rio do Meio }\end{array}$ & 5 & 10 & 8 \\
\hline \multirow{5}{*}{ Iguape, SP } & $\begin{array}{l}\text { Barragem do Valo } \\
\text { Grande }\end{array}$ & 4 & 13 & 11 \\
\hline & Colônia de Pescadores & 2 & - & - \\
\hline & Plantas de processamento & - & 2 & 1 \\
\hline & Peixarias & 4 & 5 & 3 \\
\hline & $\begin{array}{c}\text { Galpões de } \\
\text { armazenamento de } \\
\text { pescado }\end{array}$ & 3 & 2 & 2 \\
\hline \multirow{2}{*}{$\begin{array}{c}\text { Rio de } \\
\text { Janeiro, RJ }\end{array}$} & CEASA, Irajá & - & 2 & 2 \\
\hline & Feiras-livres & - & 2 & 2 \\
\hline \multirow{2}{*}{ Santos, SP } & $\begin{array}{c}\text { Rua do Peixe, Ponta da } \\
\text { Praia }\end{array}$ & 1 & 1 & 1 \\
\hline & $\begin{array}{c}\text { Mercado de Peixes, Ponta } \\
\text { da Praia }\end{array}$ & 1 & 3 & 1 \\
\hline \multirow{2}{*}{$\begin{array}{l}\text { Cananéia, } \\
\text { SP }\end{array}$} & $\begin{array}{c}\text { Planta de processamento, } \\
\text { Centro }\end{array}$ & 1 & 1 & 1 \\
\hline & Peixarias & 2 & 1 & 1 \\
\hline $\begin{array}{l}\text { São Paulo, } \\
\text { SP }\end{array}$ & CEASA, Vila Leopoldina & - & 5 & 5 \\
\hline
\end{tabular}


O terceiro questionário abrange informações relacionadas à avaliação de desempenho. Para tal, foram incluídas questões sobre equidade, eficiência (OAKERSON, 1986 apud BERKES, 2005) e empoderamento (POMEROY, 1994; TITI e SINGH, 1994 apud BERKES, 2005), comumente utilizados em alguns modelos de análise de recursos de uso comum. A definição desses critérios utilizados é apresentada a seguir:

\section{A) Equidade}

Para esse estudo, foi considerada equidade o critério que analisa a justiça social e também a justiça econômica (OAKERSON, 1986 apud BERKES, 2005). Foram considerados a distribuição dos benefícios ao longo da cadeia de valor, a adesão a programas federais e participação da mulher.

\section{Distribuição dos benefícios}

A distribuição dos benefícios é o valor adicionado ao produto (beneficiado ou não) durante os processos de distribuição e comercialização ao longo dos elos da cadeia de valor (RUSSELL e HANOOMANJEE, 2012).

\section{Programas públicos federais}

A Quadro 2 lista e descreve os oitos programas federais que foram incluídos no terceiro questionário, para avaliar a sua adesão pelos atores envolvidos nas cadeias produtivas. Todos esses programas constam no site do Ministério da Pesca e Aquicultura e fazem parte das metas do Governo Federal de implantá-los nos sistemas pesqueiros artesanais que visam melhorar as condições de vida dos pescadores propondo a inclusão social (MPA, 2014). 
Quadro 2 - Programas públicos federais sobre os quais foram indagados os atores entrevistados, seus objetivos e vigência (fonte: MPA, 2014).

\begin{tabular}{|c|c|c|}
\hline Programas federai & Objetivo & Vigência \\
\hline 1. Seguro defeso & $\begin{array}{l}\text { O benefício pago ao pescador artesanal profissional } \\
\text { durante o período que a atividade pesqueira fica } \\
\text { proibida (captura, beneficiamento, distribuição e } \\
\text { comercialização) por conta da época do defeso da } \\
\text { espécie. }\end{array}$ & $\begin{array}{l}\text { Criado em } \\
1991\end{array}$ \\
\hline $\begin{array}{l}\text { 2. Pescando } \\
\text { Letras }\end{array}$ & $\begin{array}{l}\text { Atender à necessidade urgente de alfabetização dos } \\
\text { pescadores e pescadoras profissionais e aqüicultores e } \\
\text { aqüicultoras familiares, jovens e adultos, numa } \\
\text { perspectiva de educação continuada. }\end{array}$ & $\begin{array}{l}\text { Criado } \\
\text { em } 2003\end{array}$ \\
\hline $\begin{array}{l}\text { 3. PRONATEC - } \\
\text { Pesca e } \\
\text { Aquicultura }\end{array}$ & $\begin{array}{l}\text { Qualificação e o acesso de pescadores e aquicultores à } \\
\text { formação técnica e profissional. Os cursos possuem } \\
\text { temas de interesse do setor, beneficiamento de } \\
\text { pescado, desenvolvimento de pescador profissional, } \\
\text { fiscalização ambiental, auxiliar de recursos humanos e } \\
\text { auxiliar administrativo. }\end{array}$ & $\begin{array}{l}\text { Criado } \\
\text { em } 2012\end{array}$ \\
\hline 4. Telecentros & $\begin{array}{l}\text { Ocupar o tempo que o pescador fica ocioso e promover } \\
\text { a melhoria na qualidade de vida dessas pessoas, por } \\
\text { meio da inclusão digital, permitindo reuniões com } \\
\text { apresentações didáticas, implantação de cineclubes, } \\
\text { cursos de ensino à distância e transmissões de } \\
\text { videoconferências com temas referentes à atividade } \\
\text { pesqueira. }\end{array}$ & $\begin{array}{l}\text { Criado } \\
\text { em } 2010\end{array}$ \\
\hline $\begin{array}{l}\text { 5. Plano Safra da } \\
\text { Pesca e } \\
\text { Aquicultura } \\
2012 / 2013 / 20 \\
14\end{array}$ & $\begin{array}{l}\text { Ampliar a efetividade das ações governamentais e o } \\
\text { desenvolvimento sustentável por meio de medidas de } \\
\text { estímulo à competitividade e ao empreendedorismo, } \\
\text { através de investimentos para modernizar a pesca e } \\
\text { fortalecer a indústria e o comércio pesqueiros, por } \\
\text { meio de linhas de crédito para pescadores. }\end{array}$ & $\begin{array}{l}\text { Entre os } \\
\text { anos de } \\
2012 / 201 \\
3 / 2014\end{array}$ \\
\hline $\begin{array}{l}\text { 6. Programa de } \\
\text { Subvenção } \\
\text { Econômica ao } \\
\text { Preço do Óleo } \\
\text { Diesel }\end{array}$ & $\begin{array}{l}\text { Os pescadores profissionais artesanais, armadores e } \\
\text { industriais que sejam proprietários ou arrendatários de } \\
\text { embarcações pesqueiras tem direito a comprar o óleo } \\
\text { diesel mais barato nos postos habilitados pelo MPA. }\end{array}$ & $\begin{array}{l}\text { Criado } \\
\text { em } 1997\end{array}$ \\
\hline $\begin{array}{l}\text { 7. Programa } \\
\text { Nacional de } \\
\text { Financiamento da } \\
\text { Ampliação e } \\
\text { Modernização da } \\
\text { Frota Pesqueira } \\
\text { Nacional } \\
\text { (Profrota) }\end{array}$ & $\begin{array}{l}\text { O Profrota Pesqueira compreende financiamentos para } \\
\text { a aquisição, construção, conversão, modernização, } \\
\text { substituição, adaptação e equipagem de embarcações } \\
\text { pesqueiras }\end{array}$ & $\begin{array}{l}\text { Criado } \\
\text { em } 2004\end{array}$ \\
\hline
\end{tabular}


(continuação - Quadro 2 - Programas públicos federais sobre os quais foram indagados...)

\begin{tabular}{|c|c|c|}
\hline Programas federais & Objetivo & Vigência \\
\hline $\begin{array}{l}\text { 8. Programa de } \\
\text { Apoio a } \\
\text { Cadeia } \\
\text { Produtiva do } \\
\text { Pescado }\end{array}$ & $\begin{array}{l}\text { Estabelecer uma política nacional e permanente de } \\
\text { qualificação da cadeia produtiva do pescado, tendo em } \\
\text { vista a melhora das condições de conservação do } \\
\text { pescado, a redução de custos e aumento da renda dos } \\
\text { pescadores artesanais e a oferta de pescado de melhor } \\
\text { qualidade e com preço mais acessível aos } \\
\text { consumidores, através da disponibilização de } \\
\text { equipamentos de Fábricas de Gelo, com capacidade de } \\
\text { produção aproximada de } 1,3 \text { e } 9 \text { toneladas de gelo/dia, } \\
\text { e câmaras frigoríficas. }\end{array}$ & $\begin{array}{l}\text { Criado } \\
\text { em } 2010\end{array}$ \\
\hline
\end{tabular}

\section{Participação da mulher}

A participação da mulher nas atividades ao longo da cadeia produtiva, seja como pescadora, como beneficiadora ou comerciante foi também investigada.

\section{B) Eficiência}

Para esse estudo, foi considerada eficiência o critério no qual os recursos são convertidos em produtos de forma que os processos possam ser otimizados com um retorno mais econômico (OAKERSON, 1986 apud BERKES, 2005). Foram selecionados cinco parâmetros indicativos: valor da pescaria, existência de infraestrutura, valor agregado ao produto, existência de deficiências, entraves e conflitos, e existência de medidas de regulamentação e ordenamento da pesca.

\section{Valor da pescaria}

Os dados de captura dos sistemas pesqueiros foram obtidos do site de consultas Propesq®, do Instituto de Pesca de São Paulo (http://www.propesq.pesca. sp.gov.br/propesq/web/app.php/publico/). Os valores de comercialização do atacado, desses pescados, foram obtidos para os períodos de safra, uma vez que nesse período há maior volume de captura e desembarque: para a corvina, entre março a agosto/2013; para o camarão sete-barbas entre junho a setembro/2013; e para a manjuba, entre 
outubro/2013 a março/2014. Esses valores foram obtidos através dos sites do CEASA (SP) (no caso do camarão sete-barbas e da manjuba), e do CEASA (RJ) (no caso da corvina).

\section{Existência de Infraestrutura}

Para esse parâmetro, as infraestruturas consideras foram: porto de desembarque, gelo acessível, transporte com caminhão frigorífico, armazenamento adequado (câmara fria/freezer) e maquinários apropriados. Esses itens foram levantados ao longo dos segmentos das cadeias produtivas.

\section{Valor agregado ao produto}

Foram levantados os elos que agregam valor ao produto através do processamento do produto, de processos de limpeza, filetagem, salga, defumação, congelamento ou outros.

\section{Existência de Deficiências e entraves}

O Quadro 3 lista os problemas levantados a priori e inseridos nos questionários.

Quadro 3 - Deficiências e entraves ao longo da cadeia de valor, com base em SEPA (2010), MWIRIGI e THEURI (2012).

\begin{tabular}{cl}
\hline \hline $\mathrm{N}^{\circ}$ & \multicolumn{1}{c}{ Deficiências e entraves } \\
\hline 1 & $\begin{array}{l}\text { Pouca ou inexistência de infraestrutura de desembarque, } \\
\text { armazenamento, transporte e comercialização }\end{array}$ \\
\hline 2 & Baixa inclusão do pescado nos programas federais \\
\hline 3 & $\begin{array}{l}\text { Escassez de linhas de financiamento destinadas ao setor } \\
\text { pesqueiro }\end{array}$ \\
\hline 4 & Falta ou baixa oportunidade de agregar valor ao pescado \\
\hline
\end{tabular}


(continuação - Quadro 3 - Deficiências e entraves ao longo da....)

\begin{tabular}{cl}
\hline \hline$N^{o}$ & Deficiências e entraves \\
\hline 5 & Pesca e comércio ilegal \\
\hline 6 & Baixa efetividade dos serviços de assistência técnica \\
\hline 7 & Condições precárias de trabalho \\
\hline 8 & Fraca organização da cadeia produtiva \\
\hline 9 & $\begin{array}{l}\text { Embarcações e maquinário sucateados e tecnologias de } \\
\text { beneficiamento inadequadas }\end{array}$ \\
\hline 10 & $\begin{array}{l}\text { Elevada dependência do sistema de atravessadores e } \\
\text { baixa confiabilidade para comercialização do pescado }\end{array}$ \\
\hline 11 & Falta de mão de obra especializada \\
\hline 12 & Redução dos estoques pesqueiros \\
\hline 13 & Aumento de competividade no segmento \\
\hline 14 & $\begin{array}{l}\text { Medidas técnicas erradas de proteção do recurso e do } \\
\text { ecossistema }\end{array}$ \\
\hline 15 & $\begin{array}{l}\text { Dificuldades em obter documentos necessários para a } \\
\text { pesca e comercialização }\end{array}$ \\
\hline 16 & Baixa operacionalização dos órgãos de fiscalização \\
\hline 17 & $\begin{array}{l}\text { Desvalorização do pescado no mercado } \\
\text { de qualidade }\end{array}$ \\
\hline \hline
\end{tabular}

\section{Existência de medidas de regulamentações e ordenamento da pesca}

As regulamentações ligadas ao ordenamento da pesca foram levantadas a partir dos documentos e requisitos legais existentes e disponíveis em sites de legislações pesqueiras (IBAMA, 2014; IP, 2014). Foram classificadas em: autorizações para a atividade de pesca e permissão para pescar o recurso, medidas técnicas (limitações do apetrecho, época de defeso, áreas de proibição de pesca e tamanho mínimo de captura), medidas de controle de by-catch, e subsídios (seguro-defeso e redução do valor do óleo diesel). 


\section{C) Empoderamento}

Empoderamento descreve um processo progressivo de participação, o que permite aos agentes locais tomar toda a iniciativa de trabalho de forma ativa para atingir seus interesses (FAO, 2007). Esse processo vai além do acesso amplo nas tomadas de decisões, implicando na permissão dos atores entenderem a realidade de sua situação. Foram investigados os seguintes parâmetros: organizações representativas, relação de trabalho, presença de atravessadores, e decisão para comercialização.

\section{Organizações representativas}

As organizações consideradas nos questionários foram: Colônias de Pesca, Associações e Cooperativas de Pesca, Sindicatos de Pescadores, Sindicatos de Armadores e Indústrias, Sindicatos do Comércio Atacadista e Sindicatos e Associações de estabelecimentos varejista.

\section{Relação de trabalho}

A relação de trabalho dos atores dentro de cada elo das cadeias produtivas constou do questionário 3. As perguntas foram baseadas em DIEGUES (1983), em relação à partilha de lucros realizadas pelos atores.

\section{Atravessadores}

Foi avaliada a dependência do produtor da utilização do atravessador para a comercialização do pescado até o próximo elo. Ou seja, foi avaliado se o pescador artesanal depende do atravessador para efetuar a venda, seja porque utiliza seus apetrechos de pesca ou por que há uma dependência financeira ao atravessador.

\section{Decisão de comercialização}

O poder de decisão de comercialização do produtor (pescador artesanal ou o dono da embarcação) foi investigado em quatro situações de venda possíveis: para o 
dono do material de pesca; para o atravessador; pelo melhor preço; e pela confiança ou hábito.

\subsection{Análise das estruturas das cadeias produtivas}

Entende-se por: estrutura da cadeia produtiva, os segmentos, elos e atores envolvidos, os fluxos de comercialização da produção e a frequência de ocorrência desses fluxos (De SILVA 2011); e desempenho da cadeia de valores: como um conjunto de características e comportamentos nos processos e nas atividades realizadas pelos atores ao longo da cadeia de valor (RUSSELL e HANOOMANJEE, 2012).

A análise da estrutura das cadeias de produção consiste na identificação, caracterização e função dos atores, elos e segmentos envolvidos, e também na análise dos principais fluxos de distribuição do produto. Com as informações obtidas nos questionários, foram elaborados diagramas detalhados contendo as interações entre os segmentos, os processos e os fluxos de distribuição da produção dos produtos em de cada um dos sistemas pesqueiros (Figuras 5, 12 e 20).

Também foi mapeada a intensidade do fluxo de distribuição ao longo da cadeia produtiva, ou seja, qual a frequência de uso dos canais de distribuição da produção que os atores de cada segmento identificado utilizam. A frequência de distribuição foi representada pelas diferentes larguras das setas (Figuras 5, 9, 12, 16, 20 e 25).

Para comparação das principais características de estrutura e função das cadeias estudadas, foram realizadas análises referentes: i) a existência e quantidade de atores envolvidos nas cadeias, e a proveniência dos consumidores; e ii) ao principal fluxo de produção de cada cadeia produtiva.

\subsection{Análise das estruturas das cadeias de valor}

As cadeias de valor foram mapeadas baseadas nos segmentos com participação relevante no processo de produção e distribuição do pescado, e as atividades que agregam valor em cada nível da cadeia. A avaliação sobre quais segmentos possuem participação relevante ao processo de produção foi realizada através das informações 
obtidas dos questionários, tais como: dados financeiros de compra e venda do pescado (beneficiado ou não). Medidas de estatística básica, tais como médias, médias ponderadas e porcentagens, foram utilizadas para a análise das cadeias de valores, e no caso dos valores de atacado, foram considerados os divulgados diariamente, via site de valores dos CEASA de São Paulo e CEASA do Rio de Janeiro.

Foram elaborados diagramas das cadeias de valores (Figuras 10, 17, 18, $26 \mathrm{e}$ 27) juntamente com a intensidade dos fluxos de distribuição do recurso pesqueiro (representada pelas diferentes larguras das setas), e com os valores de comercialização $(\mathrm{R} \$ / \mathrm{Kg})$ para cada segmento identificado. Os valores foram obtidos a partir da média ponderada dos dados fornecidos pelos atores de cada segmento através das entrevistas realizadas.

Para comparação das principais características da distribuição dos benefícios das cadeias estudadas, foram realizadas análises referentes: i) comparação dos processos de beneficiamento de cada cadeia; ii) comparação dos valores da margem de comercialização total (MCT), seja em valor $\mathrm{R} \$$, seja valor absoluto; e iii) comparação dos elos que definem os valores da primeira comercialização.

A margem de comercialização total (MCT) foi obtida para cada produto, com base em BJORNDAL (2010) e ALAM et al. (2012), descrita a partir da seguinte equação:

Margem de Comercialização Total (MCT) =

Preço da ultima comercialização (PPC) - Preço da primeira comercialização (PC)

O preço de primeira comercialização é referente ao preço recebido pelos pescadores, e o preço de última comercialização é o valor pago pelos consumidores finais.

\subsection{Análise do desempenho das cadeias}

A análise do desempenho das cadeias produtivas consistiu na avaliação de 12 parâmetros indicativos referente aos critérios de equidade, eficiência e empoderamento. 
Esses parâmetros, e as respectivas medidas de avaliação do desempenho, estão descritos no Quadro 4.

Quadro 4 - Sumário dos critérios de desempenho, parâmetros indicativos, elementos avaliados, e medidas de avaliação.

\begin{tabular}{|c|c|c|c|c|c|}
\hline Critério & $\begin{array}{c}\text { Parâmetro } \\
\text { indicativo }\end{array}$ & Elemento & Indicador & \multicolumn{2}{|c|}{ Medida de avaliação } \\
\hline \multirow{3}{*}{ 莺 } & 1 & $\begin{array}{c}\text { Distribuição } \\
\text { dos benefícios }\end{array}$ & $\begin{array}{c}\text { Margem de } \\
\text { comercialização bruta } \\
(\mathrm{MCB})\end{array}$ & \multicolumn{2}{|c|}{$\begin{array}{c}\text { Proporção referente à margem de } \\
\text { comercialização bruta entre os } \\
\text { segmentos }\end{array}$} \\
\hline & 2 & $\begin{array}{l}\text { Programas } \\
\text { federais }\end{array}$ & $\begin{array}{l}\text { Quantidade de } \\
\text { programas federais } \\
\text { aderidos }\end{array}$ & $\begin{array}{c}\text { Quantidade } \\
\text { Nenhuma } \\
1-2 \\
3-4 \\
\text { Acima de } 5\end{array}$ & $\begin{array}{c}\text { Desempenho } \\
\text { Nulo } \\
\text { Baixo } \\
\text { Médio } \\
\text { Alto }\end{array}$ \\
\hline & 3 & $\begin{array}{l}\text { Participação da } \\
\text { mulher }\end{array}$ & $\begin{array}{c}\text { Porcentagem de } \\
\text { participação do gênero } \\
\text { feminino }\end{array}$ & $\begin{array}{l}\text { Quantidade } \\
\text { Nenhuma } \\
\quad<50 \% \\
=50 \% \\
>50 \%\end{array}$ & $\begin{array}{c}\text { Desempenho } \\
\text { Nulo } \\
\text { Baixo } \\
\text { Médio } \\
\text { Alto }\end{array}$ \\
\hline \multirow{5}{*}{ 莺 } & 4 & $\begin{array}{l}\text { Valor da } \\
\text { pescaria }\end{array}$ & Valor anual & \multicolumn{2}{|c|}{$\begin{array}{c}\text { Preço de comercialização no } \\
\text { atacado safra }(\mathrm{R} \$) \text { x Volume de } \\
\text { captura safra }(\mathrm{kg})\end{array}$} \\
\hline & 5 & Infraestrutura & $\begin{array}{l}\text { Porcentagem de } \\
\text { infraestrutura e } \\
\text { equipamentos } \\
\text { existentes }\end{array}$ & $\begin{array}{c}\text { Quantidade } \\
\text { Nenhuma } \\
1 \%-33 \% \\
34 \%-67 \% \\
\text { Acima de } 67 \%\end{array}$ & $\begin{array}{c}\text { Desempenho } \\
\text { Nulo } \\
\text { Baixo } \\
\text { Médio } \\
\text { Alto }\end{array}$ \\
\hline & 6 & $\begin{array}{l}\text { Valor agregado } \\
\text { ao produto }\end{array}$ & $\begin{array}{l}\text { Quantidade de atores } \\
\text { que agregam valor no } \\
\text { produto } \\
\text { (beneficiamento) }\end{array}$ & $\begin{array}{l}\text { Quantidade } \\
\text { Nenhuma } \\
1-2 \\
3-4 \\
\text { Acima de } 5\end{array}$ & $\begin{array}{c}\text { Desempenho } \\
\text { Nulo } \\
\text { Baixo } \\
\text { Médio } \\
\text { Alto }\end{array}$ \\
\hline & 7 & $\begin{array}{c}\text { Deficiências e } \\
\text { entraves }\end{array}$ & $\begin{array}{c}\text { Quantidade de } \\
\text { deficiências e entraves } \\
\text { existentes }\end{array}$ & $\begin{array}{c}\text { Quantidade } \\
\text { Nenhuma } \\
1-5 \\
6-10 \\
\text { Acima de } 11\end{array}$ & $\begin{array}{c}\text { Desempenho } \\
\text { Nulo } \\
\text { Alto } \\
\text { Médio } \\
\text { Baixo }\end{array}$ \\
\hline & 8 & $\begin{array}{l}\text { Regulamenta- } \\
\text { ção e } \\
\text { ordenamento }\end{array}$ & $\begin{array}{c}\text { Quantidade de medidas } \\
\text { adotadas no sistema } \\
\text { pesqueiro }\end{array}$ & $\begin{array}{l}\text { Quantidade } \\
\text { Nenhuma } \\
1-5 \\
5-10 \\
\text { Acima de } 10\end{array}$ & $\begin{array}{c}\text { Desempenho } \\
\text { Nulo } \\
\text { Baixo } \\
\text { Médio } \\
\text { Alto }\end{array}$ \\
\hline
\end{tabular}


(continuação - Quadro 4- Sumário dos critérios de desempenho, parâmetros indicativos...)

\begin{tabular}{|c|c|c|c|c|c|}
\hline Critério & $\begin{array}{l}\text { Parâmetro } \\
\text { indicativo }\end{array}$ & Elemento & Indicador & \multicolumn{2}{|c|}{ Medida de avaliação } \\
\hline \multirow{4}{*}{ 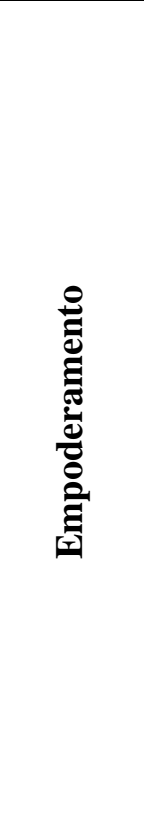 } & 9 & $\begin{array}{l}\text { Organizações } \\
\text { representativas }\end{array}$ & $\begin{array}{l}\text { Quantidade de } \\
\text { organizações } \\
\text { representativas de } \\
\text { interesse comum }\end{array}$ & $\begin{array}{c}\text { Quantidade } \\
\text { Nenhuma } \\
1-2 \\
3-4 \\
\text { Acima de } 5\end{array}$ & $\begin{array}{c}\text { Desempenho } \\
\text { Nulo } \\
\text { Baixo } \\
\text { Médio } \\
\text { Alto }\end{array}$ \\
\hline & 10 & $\begin{array}{l}\text { Relação de } \\
\text { trabalho }\end{array}$ & $\begin{array}{l}\text { Tipo de regime de } \\
\text { trabalho adotado }\end{array}$ & \multicolumn{2}{|c|}{$\begin{array}{c}\text { Sistemas de Partilha (PAR); } \\
\text { Comissão (COM); } \\
\text { Autônomo (AUT); } \\
\text { Carteira assinada (CAS) } \\
\end{array}$} \\
\hline & 11 & Atravessadores & $\begin{array}{l}\text { Porcentagem da } \\
\text { dependência dos } \\
\text { pescadores ao } \\
\text { atravessador }\end{array}$ & $\begin{array}{c}\text { Quantidade } \\
1 \%-33 \% \\
34 \%-67 \% \\
\text { Acima de } 67 \%\end{array}$ & $\begin{array}{c}\text { Desempenho } \\
\text { Alto } \\
\text { Médio } \\
\text { Baixo }\end{array}$ \\
\hline & 12 & $\begin{array}{l}\text { Decisão para } \\
\text { comercializa- } \\
\text { ção }\end{array}$ & $\begin{array}{l}\text { Porcentagem do poder } \\
\text { de decisão na } \\
\text { comercialização do } \\
\text { pescado* }\end{array}$ & $\begin{array}{c}\text { Quantidade } \\
\text { Nenhuma } \\
1 \%-33 \% \\
34 \%-67 \% \\
\text { Acima de } 67 \%\end{array}$ & $\begin{array}{c}\text { Desempenho } \\
\text { Nulo } \\
\text { Baixo } \\
\text { Médio } \\
\text { Alto }\end{array}$ \\
\hline
\end{tabular}

* Esse indicador foi avaliado conforme o desempenho do poder de decisão da venda do pescado através do cálculo da soma das respostas de melhor preço, e confiança ou costume, dividido pela soma total das respostas.

A análise da distribuição dos benefícios (parâmetro indicativo 1) consistiu em avaliar os valores de comercialização do pescado e as margens de comercialização bruta (BJORNDAL, 2010; RUSSELL e HANOOMANJEE, 2012). Foram estruturados diagramas de distribuição dos benefícios acumulados ao longo dos segmentos nas cadeias de valor, à partir dos dados de caracterização dos atores envolvidos na comercialização. E medidas de estatística básica, tais como médias, médias ponderadas e porcentagens, e os valores de atacado, divulgados diariamente, via site, foram utilizadas

No diagrama (Figuras 29, 30, 31, 32 e 33), a distribuição dos benefícios acumulados foi mapeada com base nos valores da margem de comercialização bruta (MCB) de cada fluxo de produção entre os segmentos das cadeias de valores. Com base em AHMED (2007); BJORNDAL (2010), FLOWRA et al. (2012), RUSSELL e HANOOMANJEE (2012), a MCB de cada elo é definida a partir da seguinte equação:

Margem de Comercialização Bruta $(\mathrm{MCB})=$

Preço de Venda (PV) - Preço de Compra (PC) 


\section{RESULTADOS}

Os resultados provenientes de um total de 75 respondentes, são apresentados, para cada sistema pesqueiro, quanto à: (1) estrutura e função das cadeias de produção, a partir do mapeamento dos elos e dos fluxos de produção dos recursos pesqueiros; e (2) estrutura da cadeia de valores. Posteriormente, o desempenho das cadeias de valores serão apresentados comparativamente.

\subsection{Sistema pesqueiro da corvina - frota de emalhe com redes de espera de fundo, em Ubatuba (SP)}

\subsubsection{Estrutura e função da cadeia produtiva}

$\mathrm{Na}$ cadeia produtiva da corvina capturada por embarcações de redes de emalhe de fundo e desembarcada em Ubatuba (SP), foram identificados 3 segmentos, 6 elos e 37 atores, conforme apresentados na Figura 4.

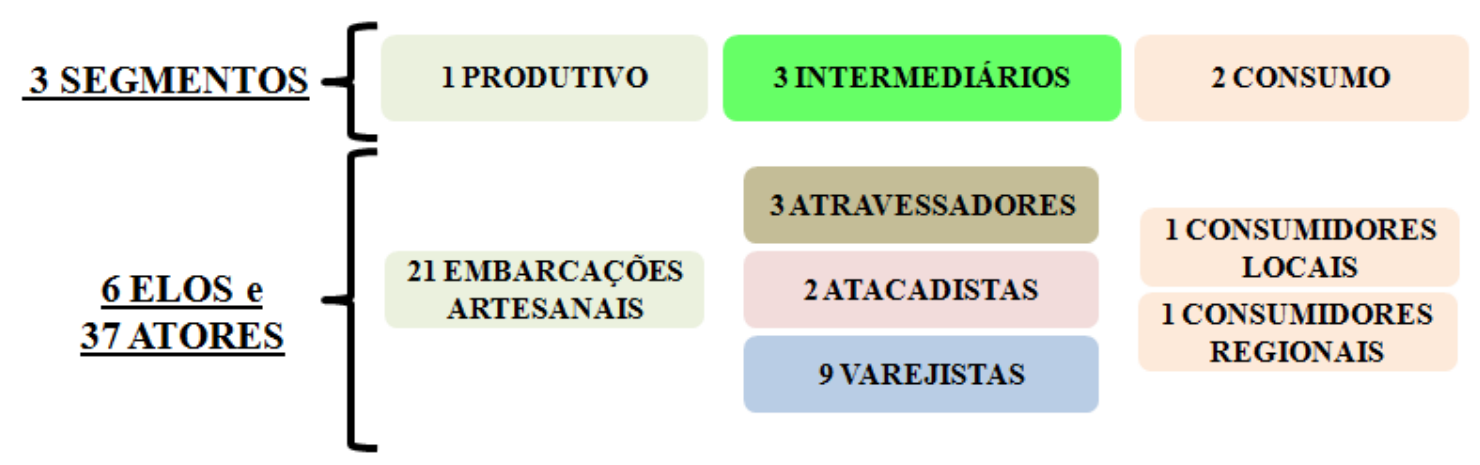

Figura 4 - Segmentos, elos e atores da cadeia produtiva da corvina.

A cadeia produtiva da corvina é apresentada detalhada na Figura 5. 


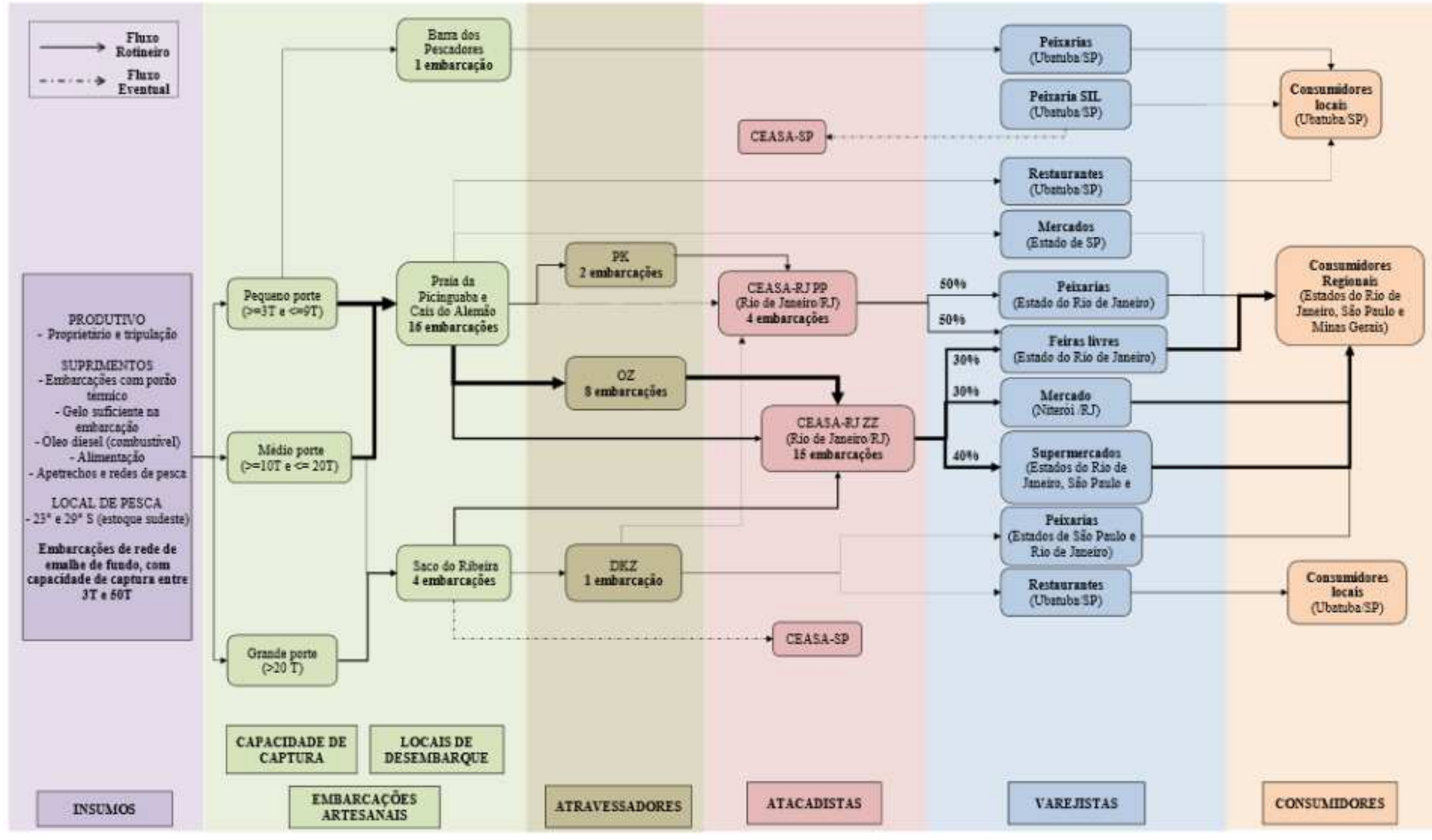

Figura 5 - Cadeia produtiva detalhada da corvina desembarcada em Ubatuba, através das embarcações de emalhe de fundo. 
Quanto ao segmento produtivo, foram identificadas 23 embarcações artesanais que operam com a rede de emalhe de fundo, sendo a corvina a espécie alvo. Dessas embarcações, 10 possuem entre 3 e 9 ton (capacidade líquida do porão - PL), oito possuem entre 10 e 20 t (PL), e 3 possuem acima de 20 ton (PL). A tripulação de cada embarcação varia entre 2 a 7 ton, sendo que sempre há um mestre responsável por todos a bordo (segurança e bem estar). Somente 10 embarcações são operadas por mestres que são os próprios proprietários, sendo que dessas 8 são embarcações de 3 - 9 ton (PL). As seis embarcações maiores de 12 ton (PL) são propriedades de armadores, de donos de peixarias ou da fábrica de gelo.

As embarcações possuem porão térmico e são abastecidas de suprimentos como gelo suficiente para conservar o peixe durante a viagem (que podem durar até 20 dias), combustível óleo diesel, rancho, além dos apetrechos de pesca (Figura 6). Esses suprimentos são fornecidos previamente à viagem (pelo armador da embarcação ou pelo atravessador) sendo pago posteriormente à venda do pescado capturado, e antes da partilha dos lucros entre os envolvidos - proprietário, mestre e tripulantes. Nos locais de desembarque do pescado, Barra dos Pescadores, Cais do Alemão e Saco do Ribeira, há píeres que facilitam o desembarque do pescado, enquanto que na Praia da Picinguaba o desembarque é realizado através de botes retirando o pescado das embarcações e descarregando na praia, não possuindo assim, qualquer estrutura de apoio para auxilio do desembarque.
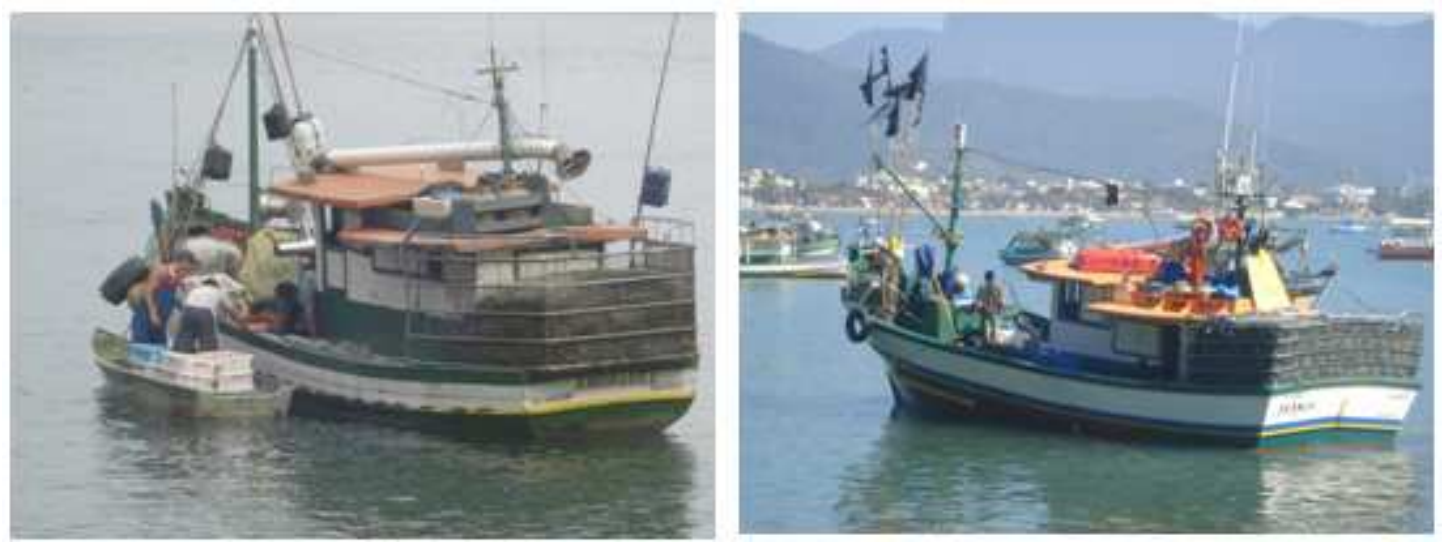

Figura 6 - Embarcações de rede de emalhe de fundo para captura da corvina, região de Ubatuba (SP). 
Foram identificados três atores como atravessadores, sendo uma peixaria (PK) de Ubatuba (SP), uma planta de processamento de pescado (DKZ) de Ubatuba (SP) e uma pessoa (OZ) de Ubatuba (SP) (Figura 7). Esses atravessadores atuam principalmente no auxílio do transporte do recurso pesqueiro para o atacadista (contratando frete ou utilizando caminhões próprios), no auxílio prévio para o abastecimento dos suprimentos (rancho) para as viagens de pesca, e também em alguns casos para o empréstimo financeiro prévio, os chamados "vales" aos tripulantes das embarcações. Por mais que exista uma planta de processamento de pescado em Ubatuba, esse ator, em relação à corvina, trabalha quase que exclusivamente como atravessador e não como beneficiador do recurso. Portanto, o papel do DKZ foi classificada como atravessador e não como planta de processamento.

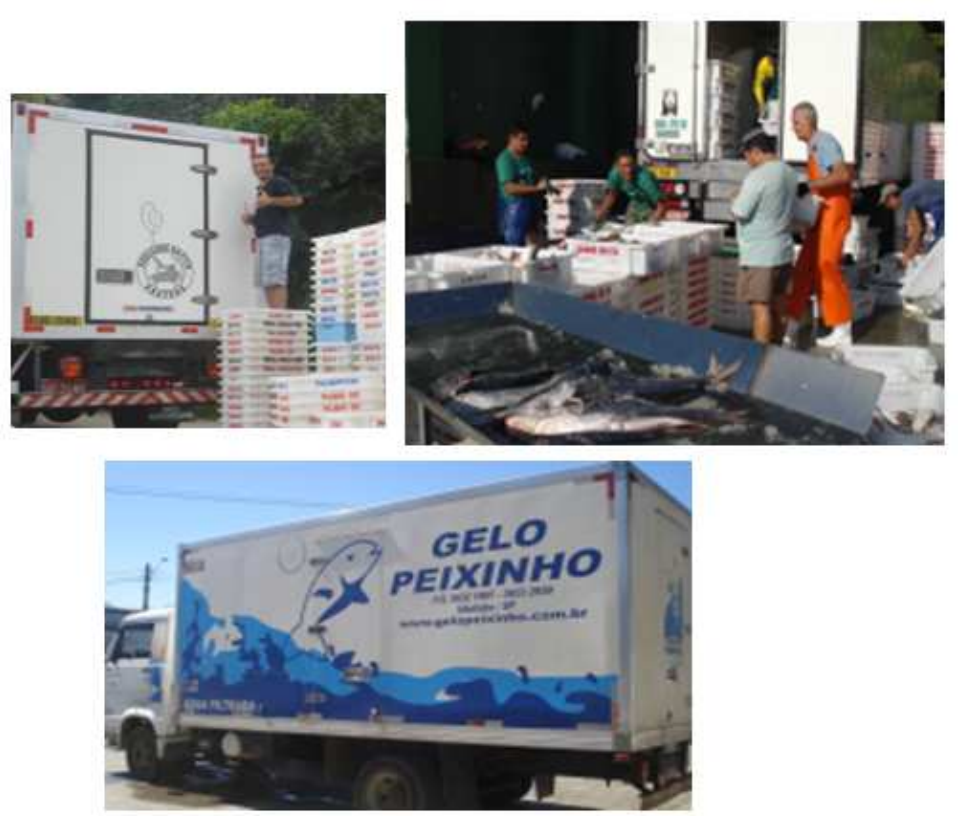

Figura 7 - Desembarque de corvinas no Cais do Alemão. Presença da equipe do atravessador PK.

Dois atores foram identificados como atacadistas. São eles: empresas do CEASA (RJ) - Unidade Grande Rio (PP e ZZ), e juntas comercializam $92 \%$ da produção de Ubatuba, na qual a firma $\mathrm{ZZ}$ trabalha com $83 \%$ dessa produção, enquanto que a firma PP trabalha somente com 17\%. Considerada a segunda maior Central de Abastecimento da América Latina - CEASA RJ - Unidade Grande Rio, tem o papel estratégico de centralizar e coordenar a distribuição de gêneros hortigranjeiros e também é responsável por contribuir com a política de segurança alimentar e nutricional 
de todo o estado, e possui um pavilhão dedicado exclusivamente ao pescado (CEASARJ, 2014).

Por fim, há nove diferentes tipos de estabelecimentos varejistas, (Figura 8). São eles: peixarias e restaurantes em Ubatuba (SP) e nos estados de SP e RJ, supermercados nos estados de SP, MG, e feiras livres no Rio de Janeiro (RJ). Nessa etapa entre o varejista e o consumidor, o pescado é comercializado fresco/resfriado (através de mercados, peixarias e feiras livres), beneficiados (limpos e filetados) pelas peixarias e feiras livres, e preparados para refeições pelos restaurantes.
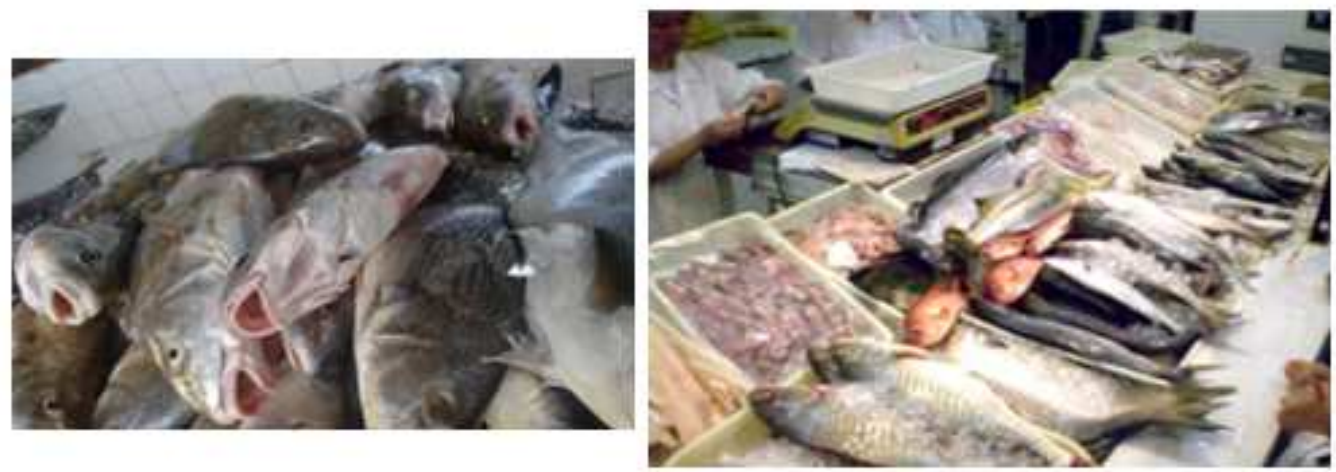

Figura 8 - Corvinas colocadas à venda nos estabelecimentos varejistas, em Ubatuba (SP) e Rio de Janeiro (RJ).

A cadeia produtiva da corvina apresenta três importantes fluxos da produção, conforme apresentado na Figura 9. O principal fluxo de distribuição corresponde a 52\% de toda a produção pesqueira de Ubatuba, e é realizado através dos elos de: embarcação artesanal $\rightarrow$ atravessador $\rightarrow$ atacadista $\rightarrow$ varejista $\rightarrow$ consumidor.

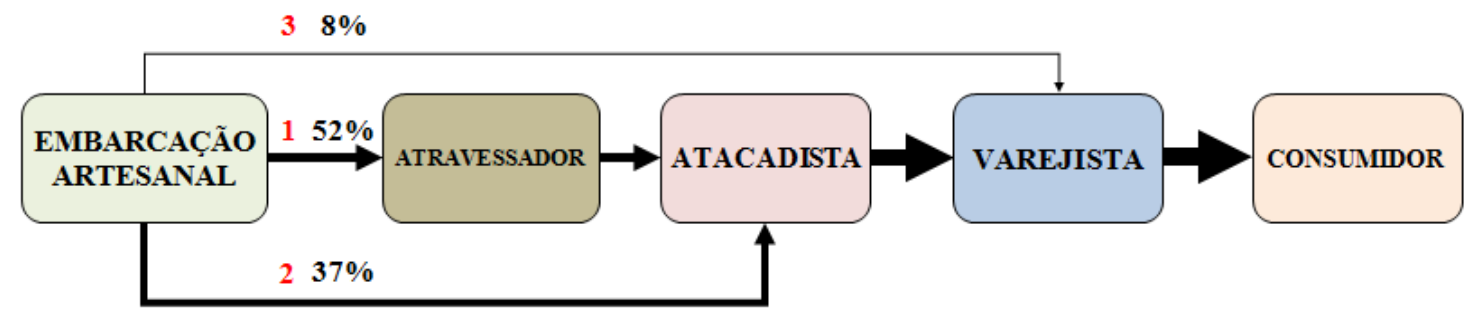

Figura 9 - Fluxos de produção discriminados pela ordem de importância na cadeia produtiva da corvina: fluxo principal $52 \%$, secundário $37 \%$, e terciário $8 \%$. As larguras das setas representam a importância relativa do fluxo. 
O transporte do recurso pesqueiro no fluxo 2 é realizado por veículos próprios do armador da embarcação, e o transporte do fluxo 3 é realizado pelos veículos próprios dos varejistas.

\subsubsection{Estrutura da cadeia de valor}

O diagrama da cadeia de valor da corvina comercializada inteira/resfriada e os preços de comercialização de cada elo está representada na Figura 10. Foi considerado somente o pescado inteiro e fresco/resfriado, pois esse processo é o mais rotineiro e usual, enquanto que o pescado beneficiado (limpo e/ou filetado) ocorre raramente pelas embarcações menores.

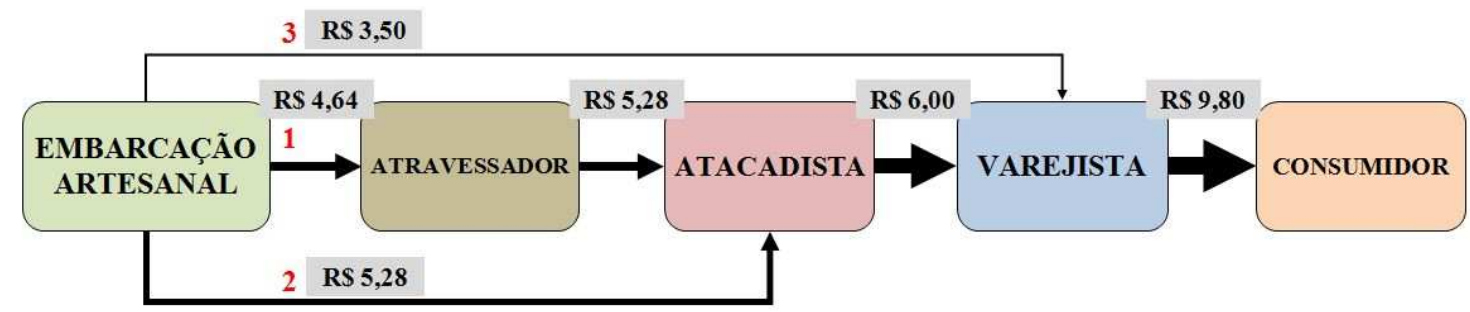

Figura 10 - Cadeia de valor da corvina, capturada por embarcações de redes de emalhe de fundo e desembarcada em Ubatuba, comercializada inteira/resfriada, 3 fluxos de comercialização, e os preços de comercialização de cada elo. Preços em reais (R\$), referentes a julho e agosto/2013.

Quando o pescador comercializa o pescado via atravessador, há uma diferença de $\mathrm{R} \$ 0,64 / \mathrm{Kg}$ comparado ao produtor que vende diretamente ao atacadista. Todas as embarcações que trabalham com o atravessador, não possuem a Nota Fiscal de Produtor, sendo essa fornecida pelo atravessador possibilitando a comercialização do pescado para o atacadista. Essa diferença de valores é referente à comissão do atravessador para auxiliar na venda, que varia entre $10-15 \%$ do preço final recebido. Das 21 embarcações identificadas, 11 delas utilizam o atravessador para comercializar o pescado para o atacadista, e somente oito embarcações realizam a comercialização direta para o atacado.

Outra forma de comercializar a corvina inteira/resfriada, porém menos usual, é através da venda direto com o varejo. Esse fluxo de comercialização é realizado somente por três embarcações, duas de pequeno porte e uma de médio porte. 


\subsection{Sistema pesqueiro do camarão sete-barbas - frota de arrasto duplo de fundo no Rio do Meio, Guarujá (SP)}

\subsubsection{Estrutura e função da cadeia produtiva}

Na cadeia produtiva do camarão sete-barbas, capturado por embarcações de arrasto duplo de fundo e desembarcada no Rio do Meio, Guarujá (SP), foram identificados 4 segmentos, 6 elos e 74 atores, conforme apresentados na Figura 11.

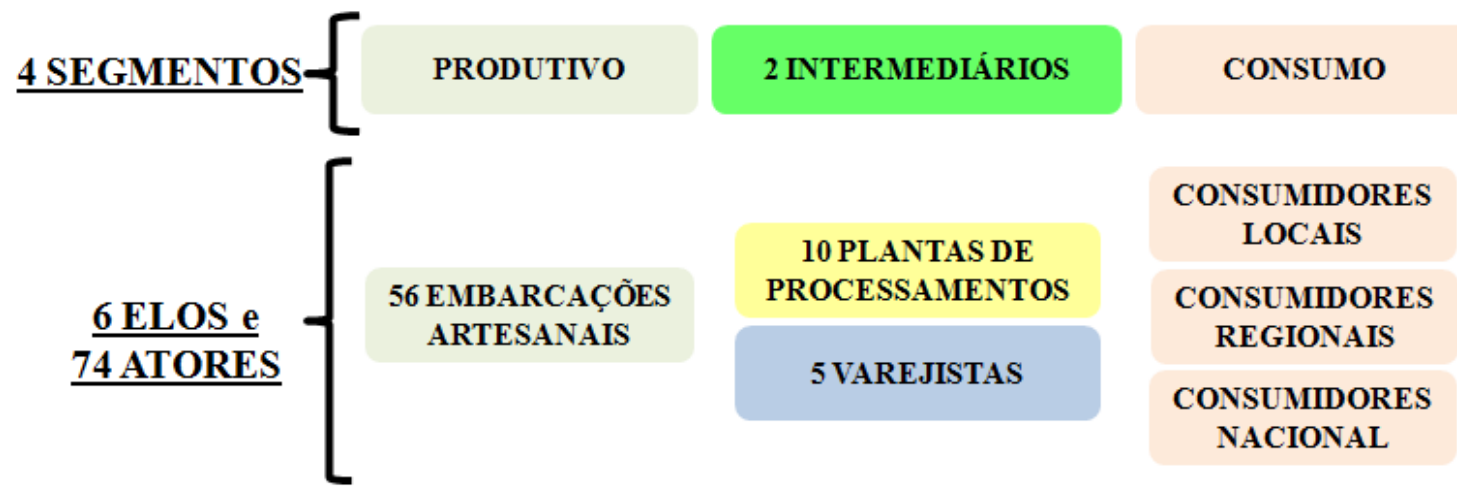

Figura 11 - Segmentos, elos e atores da cadeia produtiva do camarão sete-barbas.

A cadeia produtiva do camarão sete-barbas é apresentada detalhada na Figura 12.

Há 56 embarcações artesanais identificadas no segmento produtivo que operam com rede de arrasto duplo de fundo (Figura 13), no qual o camarão sete-barbas é o alvo da pescaria. Dessas embarcações, 42 possuem entre três e $10 \mathrm{t}$ de PL, quatro possuem entre 11 e 15 t e 10 não especificaram o tamanho.

As embarcações possuem porão térmico e são abastecidas de suprimentos como gelo suficiente para conservar o recurso pesqueiro durante a viagem (que podem durar até 15 dias), combustível óleo diesel, rancho, além dos apetrechos de pesca. Esses suprimentos são fornecidos previamente à viagem pelo armador da embarcação ou pela planta de processamento na qual a captura será comercializada. $\mathrm{O}$ valor gasto nos suprimentos é pago posteriormente à venda do pescado e antes da partilha dos lucros entre os envolvidos (proprietário, mestre e tripulantes). 


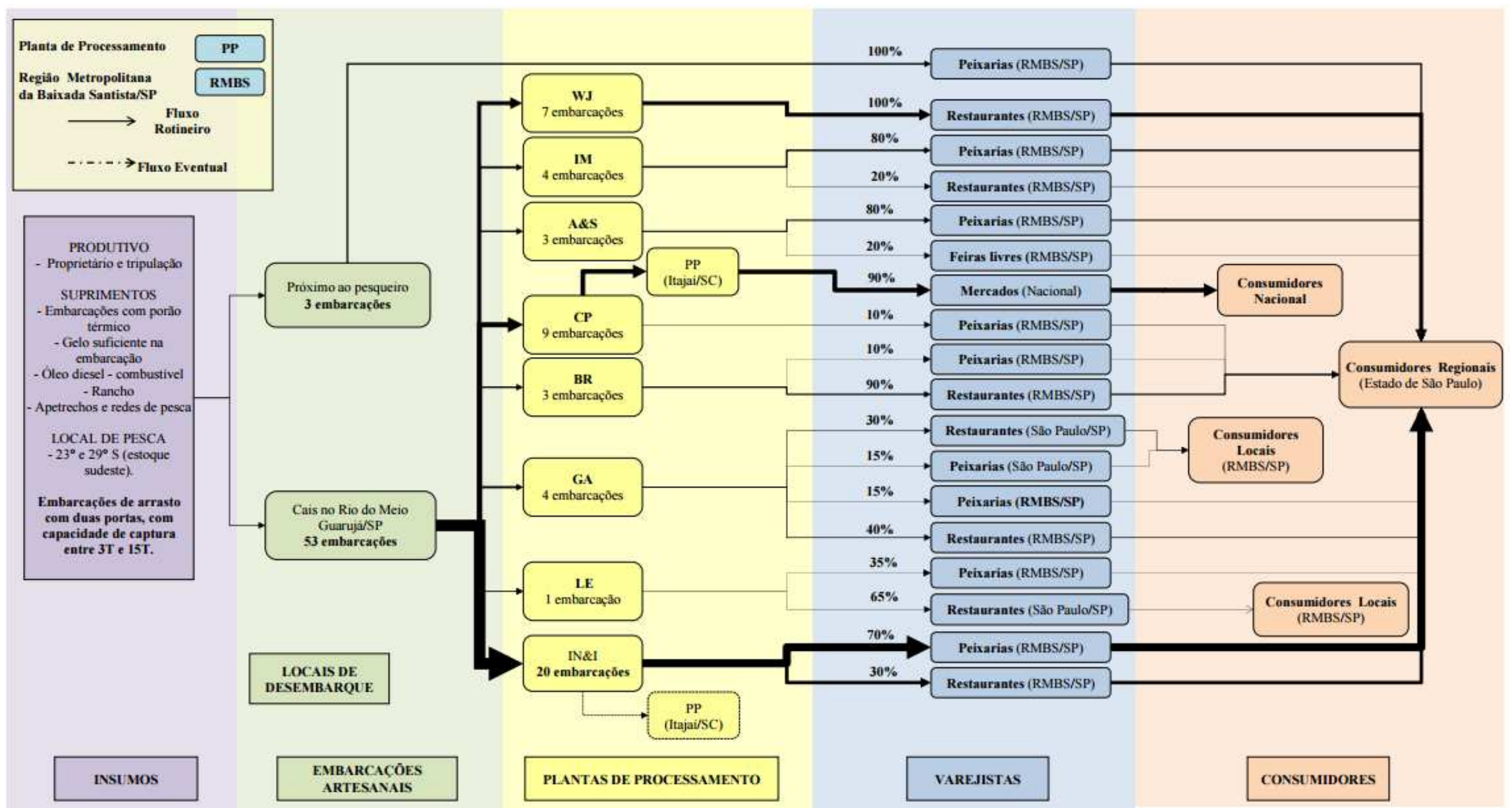

Figura 12 - Cadeia produtiva detalha do camarão sete-barbas capturado pelas embarcações de arrasto duplo de portas de fundo, e desembarcado no Rio do Meio, Guarujá (SP). 
Os locais de desembarque do camarão sete-barbas, mais frequentes, são os píeres privados das plantas de processamento localizadas no Rio do Meio. Nesses locais, há o desembarque da captura, embarque de suprimentos e da tripulação.

Foram detectadas dez plantas de processamento, sendo uma localizada em Itajaí (SC). As plantas de processamento (denominadas Indústrias de Salga), que possuem entre 12 - 29 anos de existência são os principais intermediários as quais os pescadores vendem suas capturas. Cerca de $96 \%$ da produção de camarão sete-barbas desembarcada no Rio do Meio é repassado para esses estabelecimentos. As três principais plantas de processamento que detém juntas $72 \%$ de toda a produção do camarão sete-barbas desembarcado nesse local são: a IN\&I com $40 \%$ da produção, seguidas pela CP com $18 \%$ e MA com $14 \%$.
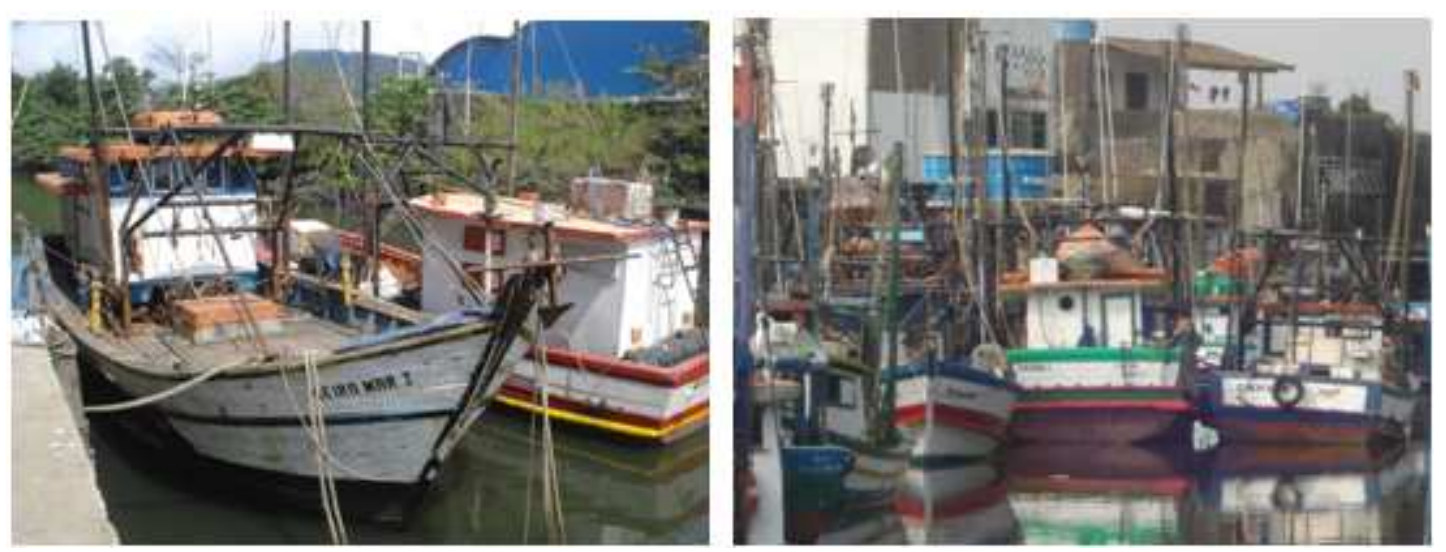

Figura 13 - Embarcações de redes de arrasto duplo e locais de desembarque no Rio do Meio, Guarujá (SP).

Algumas plantas de processamento possuem um vínculo com os pescadores no auxílio financeiro (sem juros) para a compra adiantada do rancho, apetrechos, gelo e combustível ou no adiantamento de vale. Essa ajuda financeira está diretamente ligada ao processo de venda exclusiva do camarão dessas embarcações, independentemente se é o melhor preço do mercado. Outras indústrias possuem embarcações próprias, tornando a venda da captura exclusiva.

As plantas de processamento do Rio do Meio trabalham com o beneficiamento do recurso: descabeçado ou limpo (camarão descabeçado e descascado). A diferença entre esses dois beneficiamentos se dá pelo tamanho do camarão. Portanto, há uma prévia seleção da captura junto com o processo do descabeçamento. Essa tarefa é 
realizada pelas chamadas "descabeçadeiras" (Figura 14), mulheres, que residem na região de Santos/Guarujá, e que trabalham informalmente recebendo mediante produção ao final do dia.

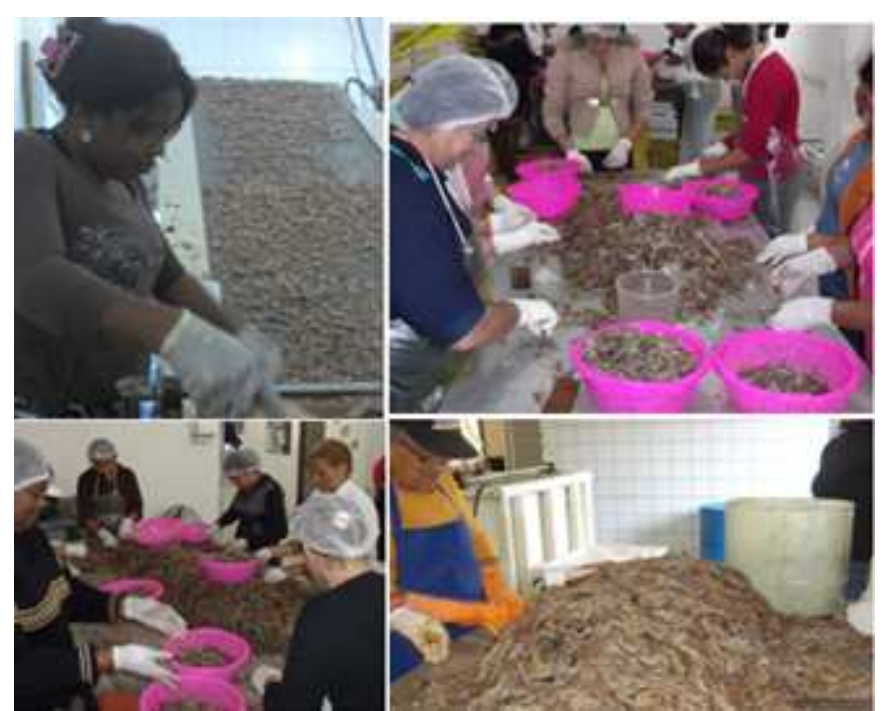

Figura 14 - "Descabeçadeiras" - mulheres que trabalham diretamente no processo de beneficiamento do camarão sete-barbas, nas plantas de processamento do Rio do Meio, Guarujá (SP).

Cinco atores do comércio varejista foram identificados: peixarias, restaurantes e feiras-livres da Região Metropolitana da Baixada Santista, e restaurantes e mercados em São Paulo (SP). Todos esses estabelecimentos são formais (Figura 15).

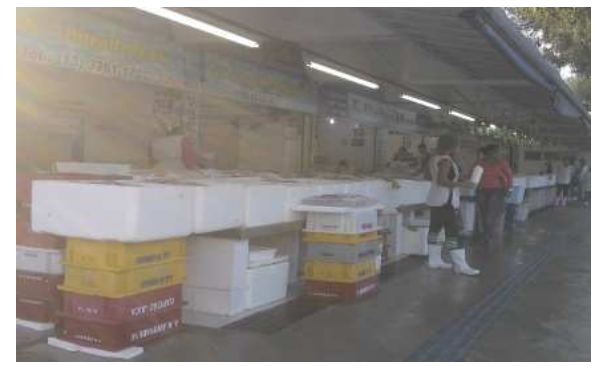

Figura 15 - Estabelecimentos varejistas de comercialização do camarão sete-barbas, no Guarujá (SP).

A cadeia produtiva do camarão sete-barbas apresenta três importantes fluxos da produção, conforme apresentado na Figura 16. O principal fluxo de distribuição corresponde a $81 \%$ de toda a produção pesqueira do Rio do Meio, e é realizado através dos elos: embarcação artesanal $\rightarrow$ planta de processamento $\rightarrow$ varejista $\rightarrow$ consumidor. 


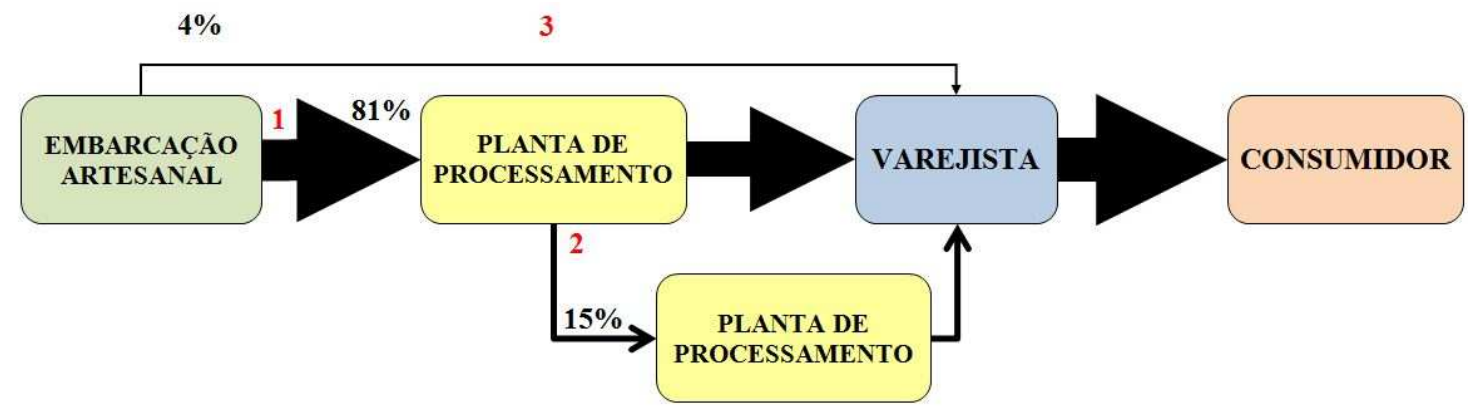

Figura 16 - Fluxos de produção discriminados pela ordem de importância na cadeia produtiva do camarão sete-barbas: fluxo principal $81 \%$, secundário $15 \%$, e terciário $4 \%$. A largura das setas representam a importância relativa do fluxo.

\subsubsection{Estrutura da cadeia de valor}

O camarão sete-barbas é comercializado após realização de dois processos distintos de beneficiamento: o descabeçamento (camarões maiores selecionados, sendo retirada somente a cabeça), e a limpeza (camarões menores que são descabeçados e descascados, conhecidos também como filé) gerando dois tipos de produtos para comercialização. O primeiro processo é realizado somente pelas plantas de processamento do Guarujá (SP), enquanto que o segundo processo é realizado pelas plantas de processamento do Guarujá (SP) e de Itajaí (SC).

A cadeia de valor do camarão sete-barbas descabeçado apresenta dois importantes fluxos de comercialização (Figura 17).

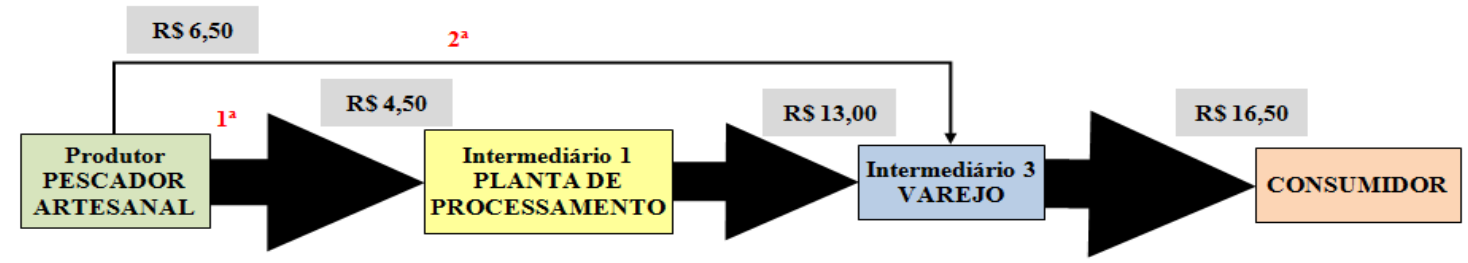

Figura 17 - Cadeia de valor do camarão sete-barbas descabeçado, com dois fluxos de comercialização principais, e os preços de comercialização de cada segmento. Preços em reais $(\mathrm{R} \$)$, referentes a junho/2013.

A cadeia de valor do sistema pesqueiro do camarão sete-barbas limpo foi elaborada e estruturada juntamente com os preços de comercialização de cada elo (Figura 18). Para o pescador há três vias de comercialização do camarão sete-barbas 
limpo: para a planta de processamento ou para o varejo, sendo a primeira via realizado por 53 embarcações e a segunda via realizado somente por 3 embarcações. As plantas de processamento acordam o preço do pescado com o pescador quando retornam da pescaria, e o pagamento à tripulação é realizado após cada duas viagens.

As embarcações que comercializam diretamente com o varejista possuem compradores certos e a venda é realizada próximo aos pesqueiros, através de uma lancha do próprio varejista até a embarcação. Não foi constatado que o pescador venda o camarão sete-barbas diretamente ao consumidor.

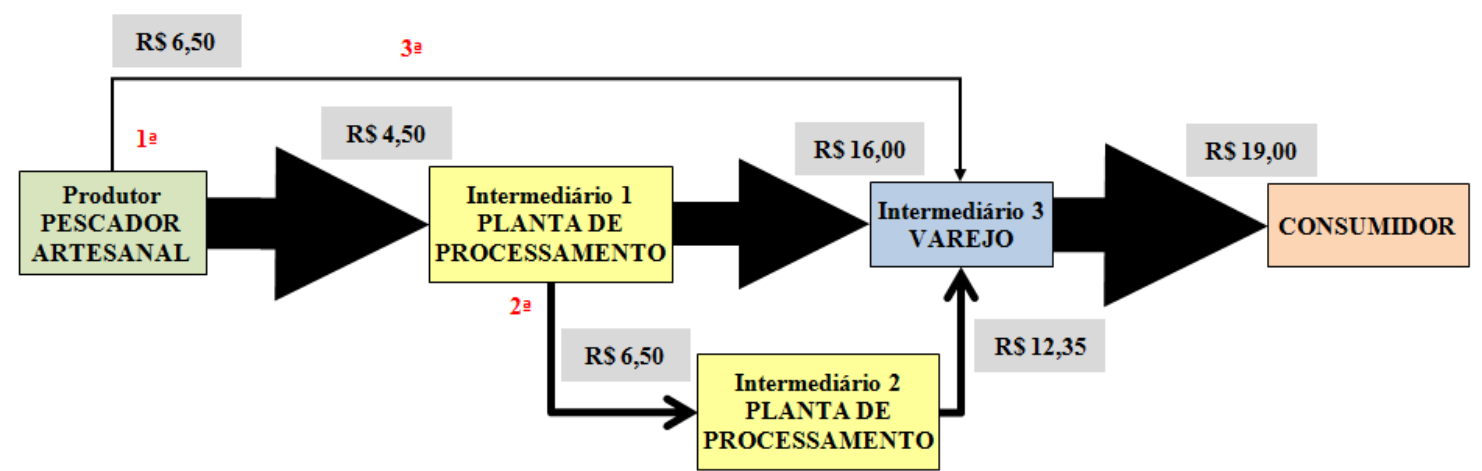

Figura 18 - Cadeia de valor do camarão sete-barbas limpo, três fluxos de comercialização principais, e os preços de comercialização de cada segmento. Preços em reais $(\mathrm{R} \$)$, referentes a junho/2013.

O preço de comercialização do camarão limpo é maior que o do camarão só descabeçado, devido à utilização da mão de obra e maquinário especializado na descascagem.

\subsection{Sistema pesqueiro da manjuba - canoas com redes de arrasto na Barragem do Valo Grande, Iguape (SP)}

\subsubsection{Estrutura e função da cadeia produtiva}

Os segmentos, os elos e os atores identificados na cadeia produtiva da manjuba, capturada por rede de arrasto, e desembarcada na Barragem do Valo Grande em Iguape (SP) são da ordem de 7 segmentos, 9 elos e 77 atores, conforme apresentado na Figura 19. 


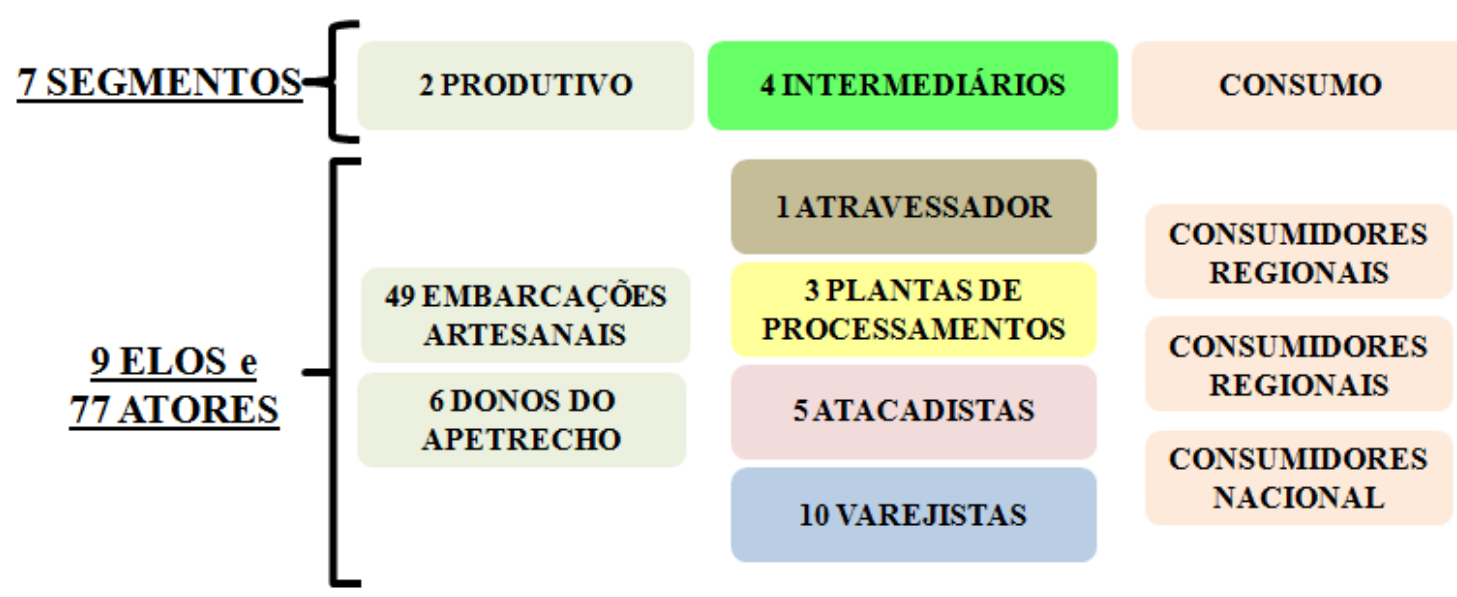

Figura 19 - Segmentos, elos e atores da cadeia produtiva da manjuba.

A cadeia produtiva da manjuba é apresentada detalhada na Figura 20.

Há 49 embarcações que operam com redes de arrasto (conhecidas como manjubeira), e todas são canoas de fibra de vidro a remo, que possuem aproximadamente 7 metros de comprimento e capacidade de armazenamento de uma tonelada (Figura 21). A tripulação varia entre 2 a 3 pescadores sendo sempre um mestre (popeiro, responsável em lançar a rede) e os demais ajudantes (proeiro e o caloeiro). Como a pescaria é realizada na praia, até duas vezes ao dia (na maré enchente), assim que a pescaria termina e os donos das redes estão a espera do pescado, não há gelo ou isopor térmico para conservar o peixe nas canoas, e a tripulação não é abastecida de rancho.

No local de desembarque não há píer ou qualquer infraestrutura que facilite o processo de deslocamento do pescado das canoas até o veículo de transporte dos donos das redes. Portanto, os pescadores carregam as caixas, de aproximadamente $22 \mathrm{~kg}$, por uma rampa até o processo de pesagem que é realizado no mesmo local (Figura 22). 


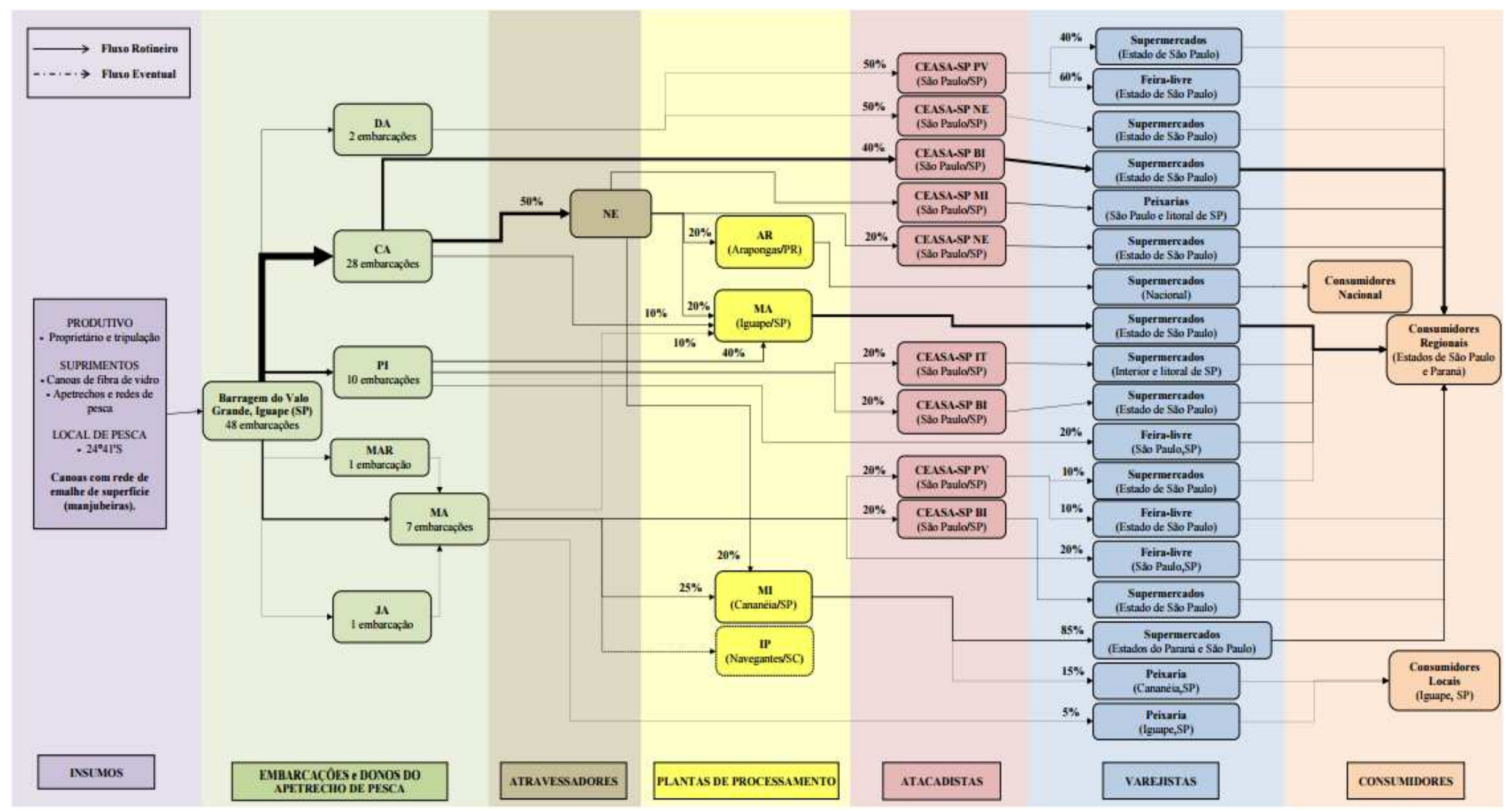

Figura 20 - Cadeia produtiva detalhada da manjuba desembarcada na prainha da Barragem do Valo Grande, Iguape (SP), através das canoas com rede de arrasto (manjubeira). 


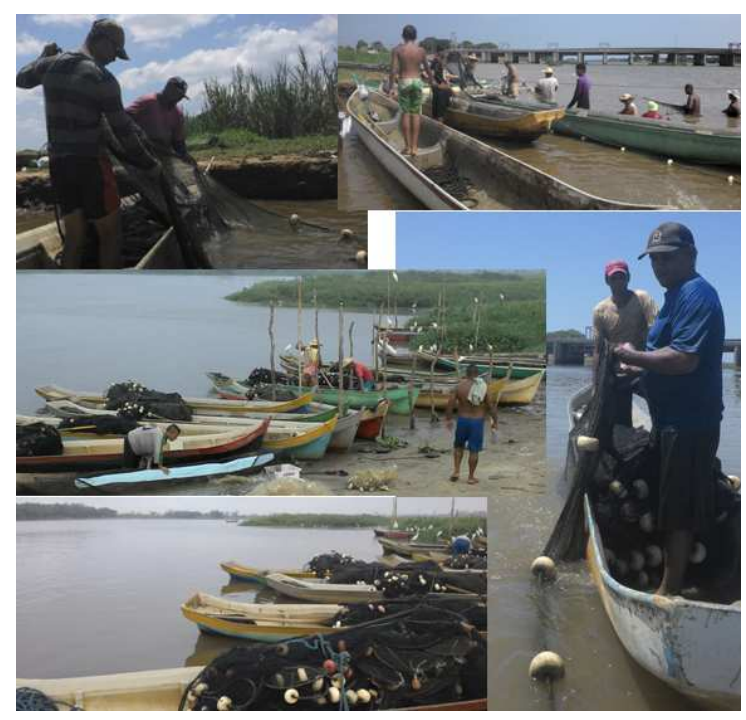

Figura 21 - Embarcações canoas com rede de arrasto para captura da manjuba, região da Barragem do Valo Grande, Iguape (SP).

Há seis donos de materiais responsáveis pelas 49 canoas, sendo somente dois deles popeiros das suas próprias canoas, assim possuem a liberdade de escolha para comercializar o pescado capturado com o armador que tem o melhor preço de compra.

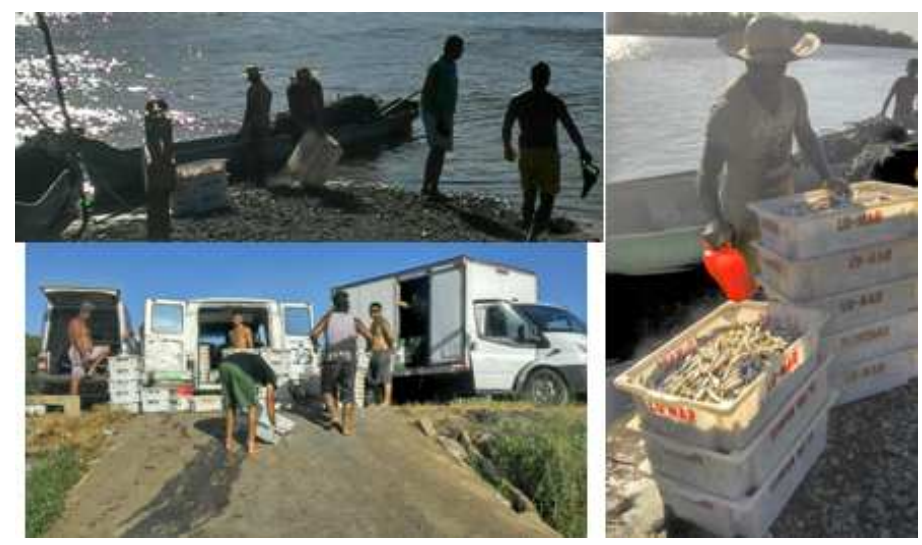

Figura 22- Desembarque de manjubas na prainha doa Barragem do Valo Grande, Iguape (SP).

Os demais donos de material, e que possuem a Nota Fiscal de Produtor, têm infraestrutura e equipamentos para armazenar, lavar e resfriar a manjuba, tais como câmaras térmicas. Os três principais armadores que detêm juntos $95 \%$ de toda a 
produção desse local são os donos de canoas CA, 57\%, seguidos pelo dono de rede PI, $20 \%$, e MA $18 \%$.

Somente um atravessador foi identificado (NE), que trabalha diretamente com um dono de rede (CA), e detém 50\% da produção. Diferentemente dos atravessadores levantados na cadeia produtiva da corvina, o NE não atua com o auxílio financeiro prévio, tal como o "vale" aos tripulantes das embarcações. Esse atravessador possui infraestrutura para armazenar, lavar e resfriar o pescado (câmaras térmicas) e local adequado para carga e descarga de veículos, como também possui caminhões frigoríficos para realizar o transporte do pescado (Figura 23), e é o único ator da cadeia que comercializa a manjuba da Barragem do Valo Grande para as três plantas de processamento identificadas.

Em relação às plantas de processamento, há duas localizadas na região de Iguape e Cananéia (SP), e uma localizada em Araponga (PR), na qual o fluxo de produção não é rotineiro. Assim, as três plantas de processamento, que possuem entre 32 - 35 anos de existência, beneficiam 38\% da produção. Duas dessas plantas de processamento (AR e MI) realizam a filetagem, o congelamento e a evisceração, enquanto que a MA realiza somente a salga da manjuba.

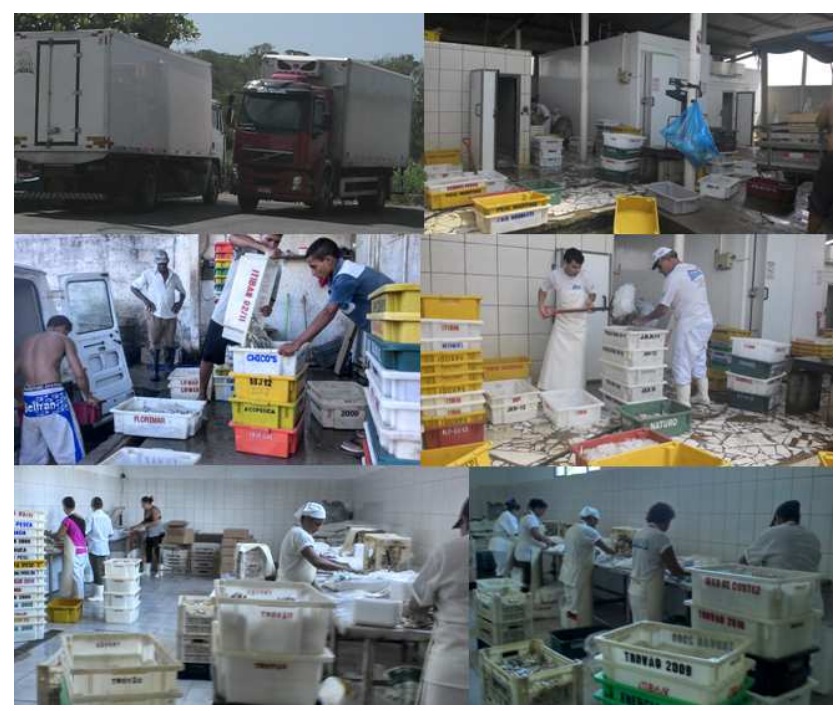

Figura 23 - Infraestrutura dos atores envolvidos na cadeia produtiva da manjuba: donos de materiais, atravessadores e plantas de processamento, em Iguape (SP).

Há cinco empresas atacadistas do CEAGESP - Unidade Vila Leopoldina (Figura 24), e juntas comercializam mais da metade da produção de Barragem do Valo 
Grande. A empresa BI trabalha com 55\% dessa produção, caracterizando a mais importante, seguida da empresa NE que trabalha somente com 14\%, e da empresa MI com $10 \%$ da participação. A Companhia de Entrepostos e Armazéns Gerais de São Paulo - CEAGESP, terceira maior mercado atacadista do mundo e primeiro da América Latina, é ponto de referência na venda de pescado integrando cerca de 60 empresas de pesca e comercialização de peixes constitui-se um centro atacadista de porte de pescado no país (CEAGESP, 2014).

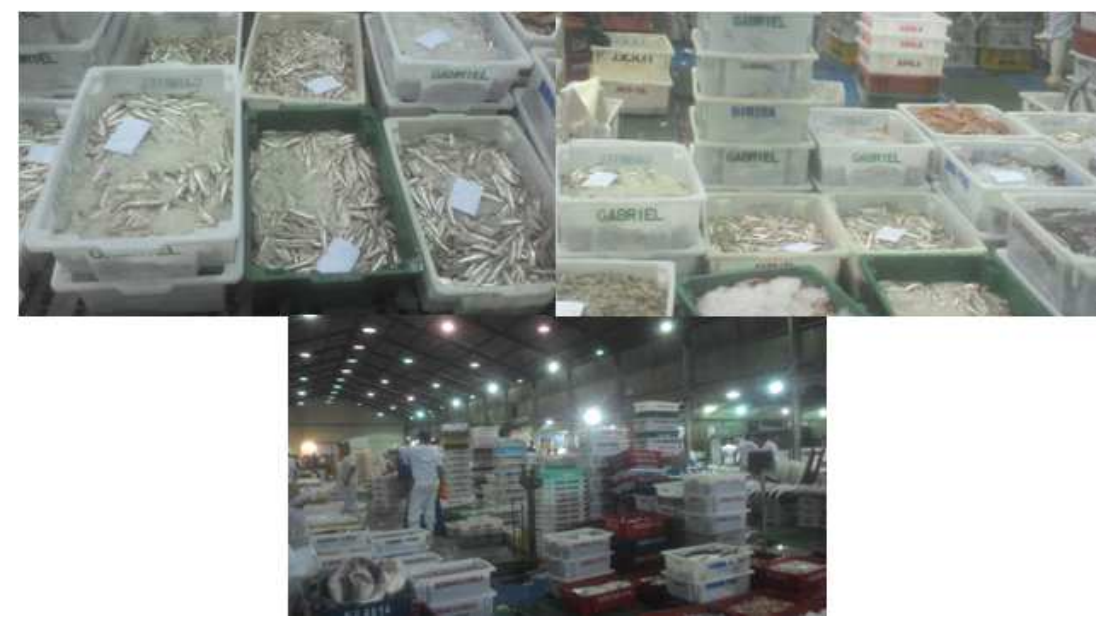

Figura 24 -Atacadistas no CEAGESP, Vila Leopoldina, São Paulo (SP).

Por fim, há 10 diferentes tipos de estabelecimentos comerciais: supermercados nos estados de SP e PR, litoral e interior de SP e nacional, peixarias em Cananéia (SP) e Iguape (SP), São Paulo e litoral (SP), feiras livres em São Paulo (SP) e todo o estado de SP.

A cadeia da manjuba apresenta cinco importantes fluxos da produção, conforme apresentado na Figura 25. O principal fluxo de distribuição corresponde a $43 \%$ de toda a produção pesqueira desembarcada na prainha da Barragem do Valo Grande, e é realizado através dos atores de: pescador artesanal $\rightarrow$ dono de material $\rightarrow$ atacado $\rightarrow$ varejo $\rightarrow$ consumidor. 


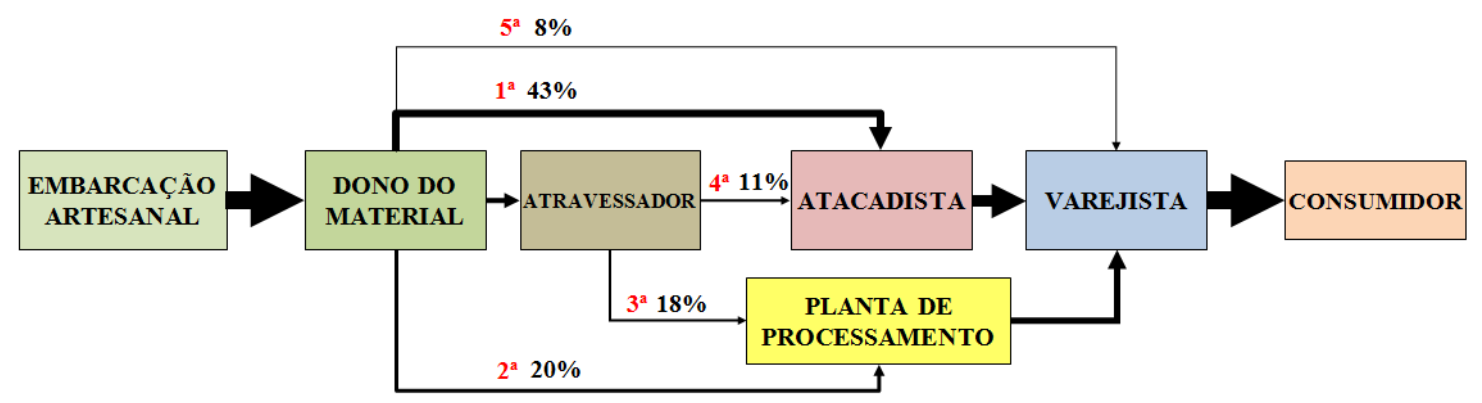

Figura 25 - Fluxos de produção discriminados pela ordem de importância na cadeia produtiva da manjuba: fluxo principal $43 \%$, secundário $20 \%$, terciário $18 \%$, quaternário $11 \%$ e quinário $8 \% \%$. As larguras das setas representam a importância relativa do fluxo.

\subsubsection{Estrutura da cadeia de valor}

A manjuba é comercializada através de três processos: inteira/resfriada; beneficiada salgada, e eviscerada (em forma de filé), sendo o primeiro processo mais usual (cerca de $62 \%$ da produção total).

A cadeia de valor da manjuba inteira/resfriada é realizada por todos os segmentos identificados (pescador, dono do material, atravessador, atacadista e varejista), enquanto que na cadeia de valor da manjuba processada, o atacadista não participa. Dois diagramas da cadeia de valor foram elaborados, um referente à manjuba inteira/resfriada, e o outro referente à manjuba salgada e eviscerada.

A manjuba desembarcada na Barragem do Valo Grande, Iguape (SP) é capturada por redes de arrasto, conhecida como manjubeira, e, portanto possui um valor de comercialização maior que as capturadas por rede de espera de superfície (conhecidas como currico), uma vez que as manjubas não emalham na rede de arrasto, como acontece na rede de currico, mantendo-as inteiras e sem ferimentos. A diferença no preço da primeira venda, entre o pescado capturado pela manjubeira e pelo currico, pode chegar a $\mathrm{R} \$ 0,50 / \mathrm{Kg}$.

A cadeia de valor do sistema pesqueiro da manjuba inteira/resfriada foi elaborada e estruturada juntamente com os preços de comercialização de cada segmento (Figura 26). Há cinco importantes fluxos de produção. 


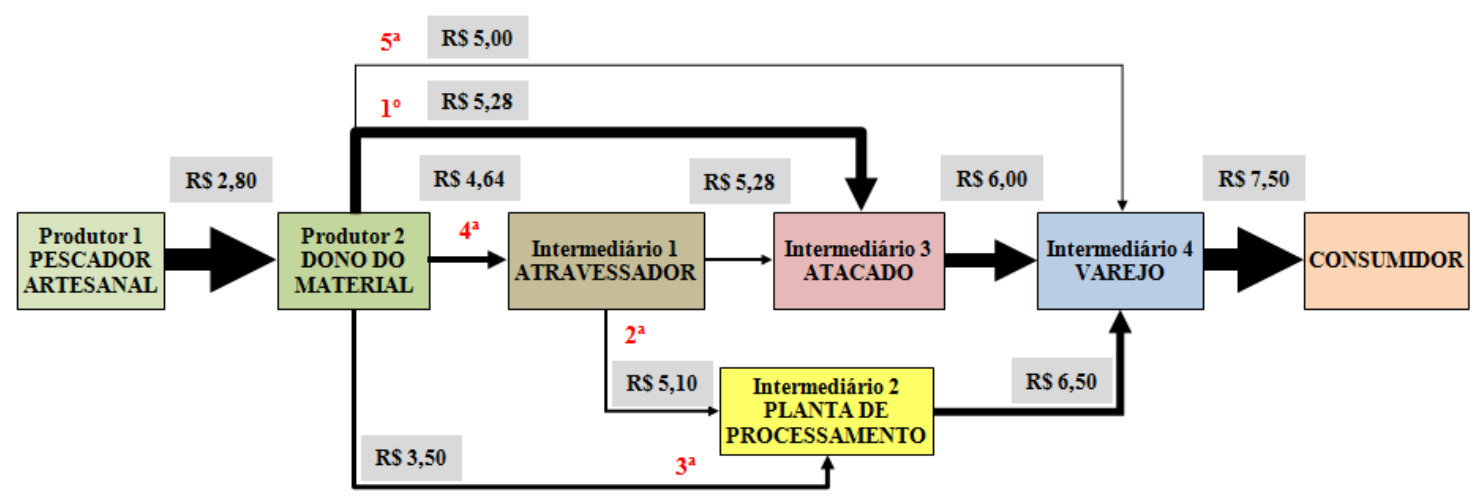

Figura 26 - Cadeia de valor da manjuba inteira/resfriada desembarcada na prainha da Barragem do Valo Grande, Iguape (SP), quatro fluxos de comercialização principais, e os preços de comercialização de cada segmento. Preços em reais $(\mathrm{R} \$)$, referentes à fev/2014.

O pescador possui somente uma via de comercialização: o dono do material. O dono do material acerta o valor com o pescador, semanalmente, e o pagamento é realizado diariamente ou no fim da semana. A vantagem de o pescador acordar o valor previamente com o dono do material é ele saber o valor exato que irá receber pela sua captura, evitando esperar o pescado ser vendido, para depois ter o valor repassado. $\mathrm{O}$ mesmo ocorre para o dono do material quando comercializa o pescado com as plantas de processamento e com o varejo. Em contrapartida, quando o dono do material comercializa com o atacadista direto, ou via atravessador, ele só recebe após o valor estabelecido no dia ao comprador do atacadista. No caso do dono do material que comercializa via atravessador para o atacadista, o mesmo só recebe o pagamento do recurso capturado, após descontos da comissão do atravessador e das despesas de: frete (gelo e transporte), taxas de descarga do caminhão e estacionamento e diária do motorista.

A cadeia de valor do sistema pesqueiro da manjuba beneficiada salgada e eviscerada foi elaborada e estruturada juntamente com os preços de comercialização de cada segmento (Figura 27). Há dois importantes fluxos da produção. 


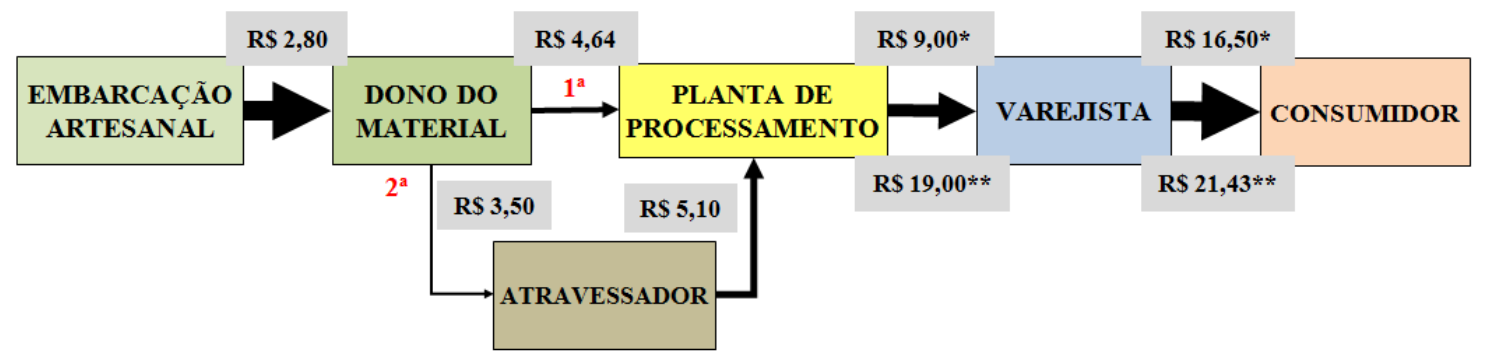

Figura 27 - Cadeia de valor da manjuba beneficiada (salgada* e eviscerada**) desembarcada na prainha da Barragem do Valo Grande, Iguape (SP), através das canoas com rede de arrasto (manjubeira), e os preços de comercialização de cada segmento. Preços em reais $(\mathrm{R} \$)$, referentes à fev/2014.

\subsection{Análise comparativa da estrutura e funcão da cadeia produtiva e de valores}

A Tabela 1 apresenta o número de atores de cada segmento das três cadeias produtivas estudadas. Nota-se que o número de embarcações da cadeia produtiva do camarão sete-barbas é superior às demais cadeias $(n=56)$.

A cadeia produtiva da manjuba conta com a participação de um número maior de atores (produtores, atravessadores, plantas de processamento, atacadistas e varejista), sendo assim, a mais complexa dentre as três. Em contrapartida, a cadeia produtiva do camarão sete-barbas é a mais simples, com participação somente dos produtores, plantas de processamento e varejo.

Outro destaque é a proveniência dos principais consumidores: enquanto a cadeia da corvina restringe-se a alguns estados, o camarão sete-barbas e a manjuba têm abrangência em todo o país, sendo que a manjuba possui a maior participação de complexidade nacional. 
Tabela 1 - Número de atores nos diversos elos das cadeias produtivas e proveniência dos consumidores dos sistemas pesqueiros estudados. (0 não participa).

\begin{tabular}{|c|c|c|c|c|c|c|c|}
\hline \multirow[b]{3}{*}{$\begin{array}{l}\text { Cadeia } \\
\text { produtiva }\end{array}$} & \multicolumn{7}{|c|}{ Elos } \\
\hline & \multirow[b]{2}{*}{ 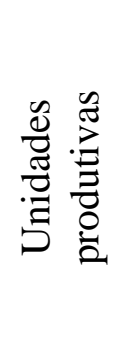 } & \multicolumn{5}{|c|}{ Intermediários } & \multirow[b]{2}{*}{$\begin{array}{l}\text { Proveniência } \\
\text { dos principais } \\
\text { consumidores }\end{array}$} \\
\hline & & 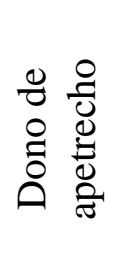 & 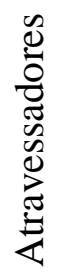 & 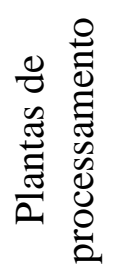 & 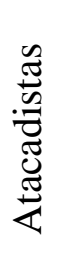 & 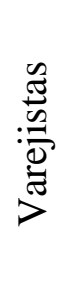 & \\
\hline 1. Corvina & 21 & 0 & 3 & 0 & 2 & 9 & $\begin{array}{c}\text { Estados de } \\
\text { SP, RJ e MG }\end{array}$ \\
\hline $\begin{array}{l}\text { 2. Camarão } \\
\text { sete-barbas }\end{array}$ & 56 & 0 & 0 & 10 & 0 & 5 & $\begin{array}{c}\text { Estado de SP, } \\
\text { e Nacional }\end{array}$ \\
\hline 3. Manjuba & 49 & 6 & 1 & 3 & 5 & 10 & $\begin{array}{c}\text { Estados de } \\
\text { SP e PR, e } \\
\text { Nacional }\end{array}$ \\
\hline
\end{tabular}

Outro viés que caracteriza a complexidade da cadeia produtiva é o fluxo de distribuição comparado na Figura 28. O fluxo principal de distribuição da produção da manjuba ocorre com a frequência de $43 \%$, através dos segmentos produtor, dono do material, atacado e varejo. Já na cadeia produtiva do camarão sete-barbas, que é uma cadeia simples, a frequência de distribuição da produção é de $81 \%$, através dos segmentos produtor, planta de processamento e varejo.

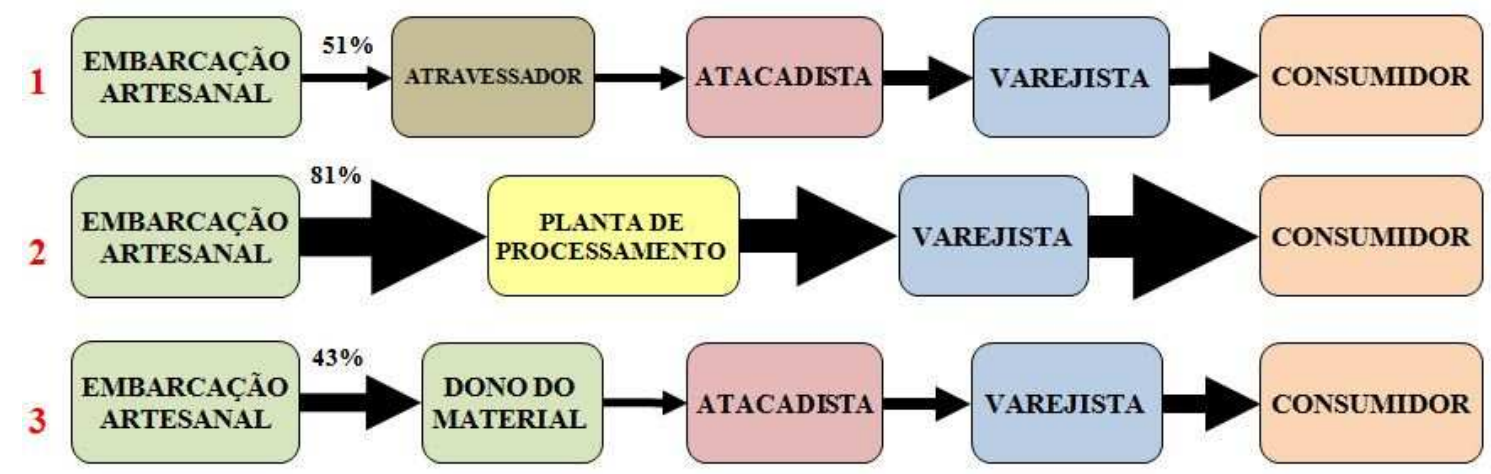

Figura 28 - Comparação dos fluxos de distribuição principais de cada uma das três cadeias produtivas. 1) corvina; 2) camarão sete-barbas; 3) manjuba. 
Outra evidência de que a cadeia produtiva da manjuba é a mais complexa está na comparação entre os processamentos e beneficiamentos realizados nos recursos (Tabela 2). Na cadeia da manjuba, além da comercialização do pescado inteiro, inteira/resfriada, $38 \%$ da produção total da manjuba é também beneficiada através de três tipos de processamento, filetagem, evisceração e salga, realizados por diferentes tipos de plantas de processamento na região de Iguape e Cananéia (SP) e Araponga (PR). Já apenas uma pequena parcela da produção da corvina $(4,7 \%)$ é beneficiada pela única planta de processamento, em Ubatuba,SP.

Tabela 2 - Produção processada por cadeia produtiva.

\begin{tabular}{|c|c|c|}
\hline $\begin{array}{l}\text { Cadeia } \\
\text { produtiva }\end{array}$ & $\begin{array}{l}\text { Quantidade da } \\
\text { produção }(\%)\end{array}$ & $\begin{array}{c}\text { Tipo de } \\
\text { processamento e } \\
\text { beneficiamento } \\
\end{array}$ \\
\hline Corvina & $4,7 \%$ & 1. Filetagem \\
\hline $\begin{array}{l}\text { Camarão } \\
\text { sete-barbas }\end{array}$ & $100 \%$ & $\begin{array}{l}\text { 1. Descabeçado } \\
\text { 2. Limpo }\end{array}$ \\
\hline Manjuba & $38 \%$ & $\begin{array}{ll}\text { 1. } & \text { Filetagem } \\
\text { 2. } & \text { Evisceração } \\
\text { 3. } & \text { Salga }\end{array}$ \\
\hline
\end{tabular}

A comparação dos valores da margem de comercialização total (em valores $\mathrm{R} \$$ e valores absolutos) está esquematizada na Tabela 3. As maiores margens são da comercialização da manjuba eviscerada ( 7,6 vezes maior) e da manjuba salgada $(5,9$ vezes maior). Em contrapartida, as menores margens são da manjuba inteira/resfriada (2,6 vezes maior) e da corvina inteira/resfriada ( 2,1 vezes maior).

A comparação dos elos que definem os valores da primeira comercialização, em $(\mathrm{R} \$ / \mathrm{kg})$, nas três cadeias de valores também está esquematizada na Tabela 3. O preço da primeira comercialização da corvina é estabelecido pelo atacadista, enquanto que o valor do camarão sete-barbas é estabelecido semanalmente pela planta de processamento, e por fim, o preço da primeira comercialização da manjuba é estabelecido pelo atacadista. 
Tabela 3 - Margem de comercialização total, em valores em $\mathrm{R} \$$ e valores absolutos, e segmentos que definem o preço da primeira comercialização. Valores em reais (R\$) referentes à safra de cada recurso pesqueiro: de julho e agosto/2013 para a corvina; de junho/2013 para o camarão sete-barbas; e de fevereiro/2014 para a manjuba.

\begin{tabular}{|c|c|c|c|}
\hline \multirow{2}{*}{ Cadeia de valor } & \multicolumn{2}{|c|}{$\begin{array}{c}\text { Margem de } \\
\text { comercialização total }\end{array}$} & \multirow{2}{*}{$\begin{array}{l}\text { Segmento que define o } \\
\text { preço da primeira } \\
\text { comercialização }\end{array}$} \\
\hline & $\begin{array}{l}\text { Valor } \\
\text { em R\$ }\end{array}$ & $\begin{array}{c}\text { Valor } \\
\text { absoluto }\end{array}$ & \\
\hline Corvina inteira/resfriada & 5,16 & 2,1 & CEASA RJ \\
\hline Manjuba inteira/resfriada & 4,70 & 2,6 & \multirow{3}{*}{ CEASA SP } \\
\hline Manjuba salgada & 13,70 & 5,9 & \\
\hline Manjuba eviscerada & 18,63 & 7,6 & \\
\hline $\begin{array}{c}\text { Camarão sete-barbas } \\
\text { limpo }\end{array}$ & 14,50 & 4,0 & \multirow{2}{*}{$\begin{array}{c}\text { Plantas de } \\
\text { processamento }\end{array}$} \\
\hline $\begin{array}{c}\text { Camarão sete-barbas } \\
\text { descabeçado }\end{array}$ & 12,00 & 3,6 & \\
\hline
\end{tabular}

\subsection{Desempenho das cadeias de valores}

\subsubsection{Equidade}

\section{Distribuição dos benefícios}

\section{Corvina}

O diagrama de distribuição dos benefícios acumulados ao longo da cadeia de valor da corvina inteira e resfriada dos três fluxos de comercialização está esquematizado na Figura 29.

Nos dois primeiros fluxos, a maior margem de comercialização bruta (MCB) é do pescador, e a menor é a atravessador. Porém, quando o pescador comercializa direto com o varejo, a maior MCB é a do varejista. Porém, o pescador tem algumas vantagens nessa comercialização: a possibilidade de saber o preço do pescado, e aceitar ou não, no momento da comercialização, além de receber no ato o valor final da venda. 


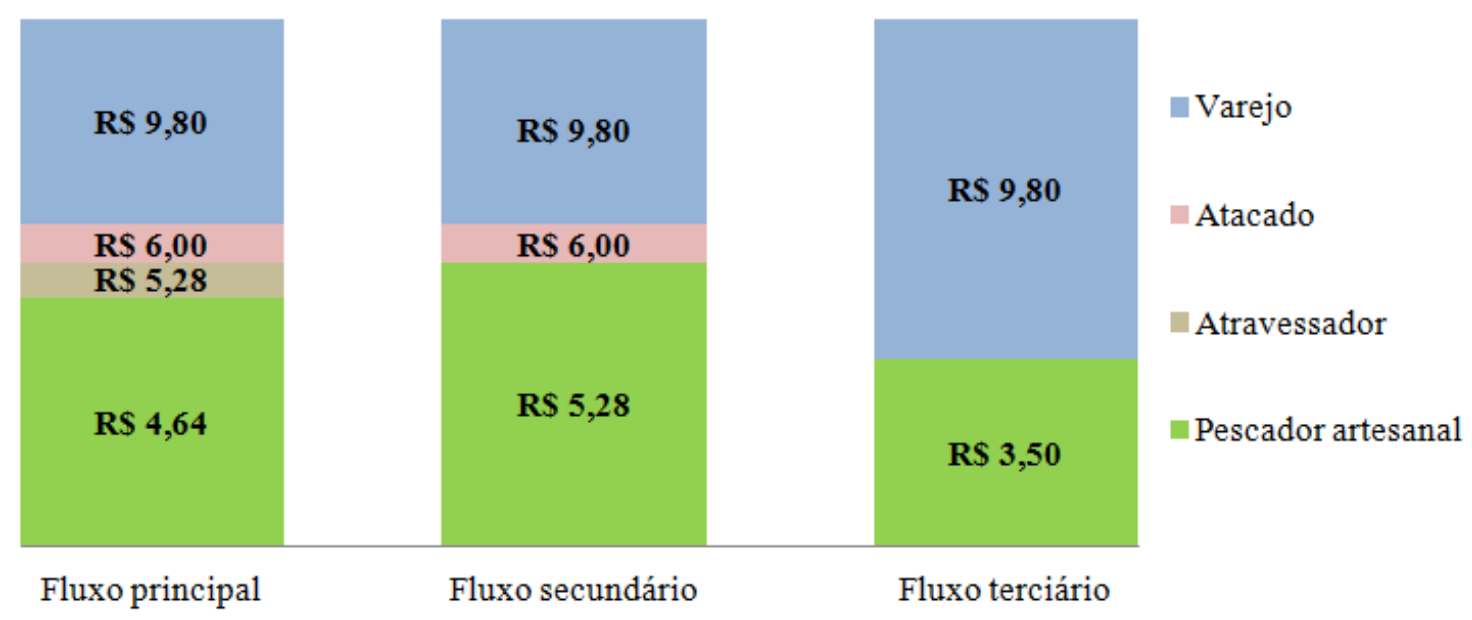

Figura 29 - Diagrama de distribuição dos benefícios acumulados ao longo da cadeia de valor da corvina inteira e resfriada, referente aos fluxos principal, secundário e terciário. Preços em reais (R\$), referentes a julho e agosto/2013.

\section{Camarão sete-barbas}

Para cada fluxo de produção da cadeia de valor do camarão sete-barbas descabeçado, há um diagrama de distribuição dos benefícios acumulados esquematizadas na Figura 30.

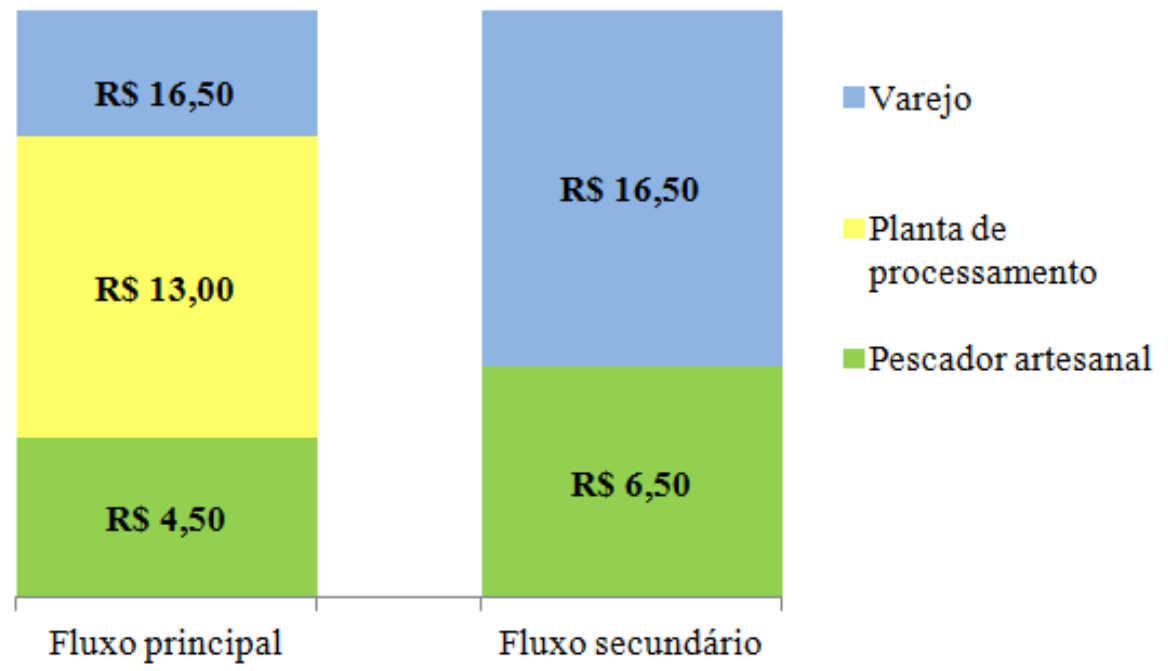

Figura 30 - Diagrama de distribuição dos benefícios acumulados ao longo da cadeia de valor do camarão sete-barbas descabeçado, referente aos fluxos principal e secundário. Preços em reais (R\$), referentes a junho/2013. 
No fluxo de comercialização principal do camarão sete-barbas descabeçado, o pescador recebe $\mathrm{R} \$ 4,50 / \mathrm{kg}$ pela venda à planta de processamento, enquanto que no fluxo secundário, o pescador que comercializa direto com o varejo recebe $\mathrm{R} \$ 6,50 / \mathrm{kg}$. Ou seja, o pescador do fluxo secundário, detém uma maior MCB se comercializado direto com o varejo.

Para cada fluxo de produção da cadeia de valor do camarão sete-barbas limpo, foi elaborado um diagrama de distribuição dos benefícios acumulados (Figura 31).

No fluxo principal a maior MCB é do segmento da planta de processamento, enquanto que nos demais fluxos, a maior margem é detida pelo varejo. Uma vez que a planta de processamento faz o papel de atravessador, no fluxo secundário, ela detém a menor MCB.

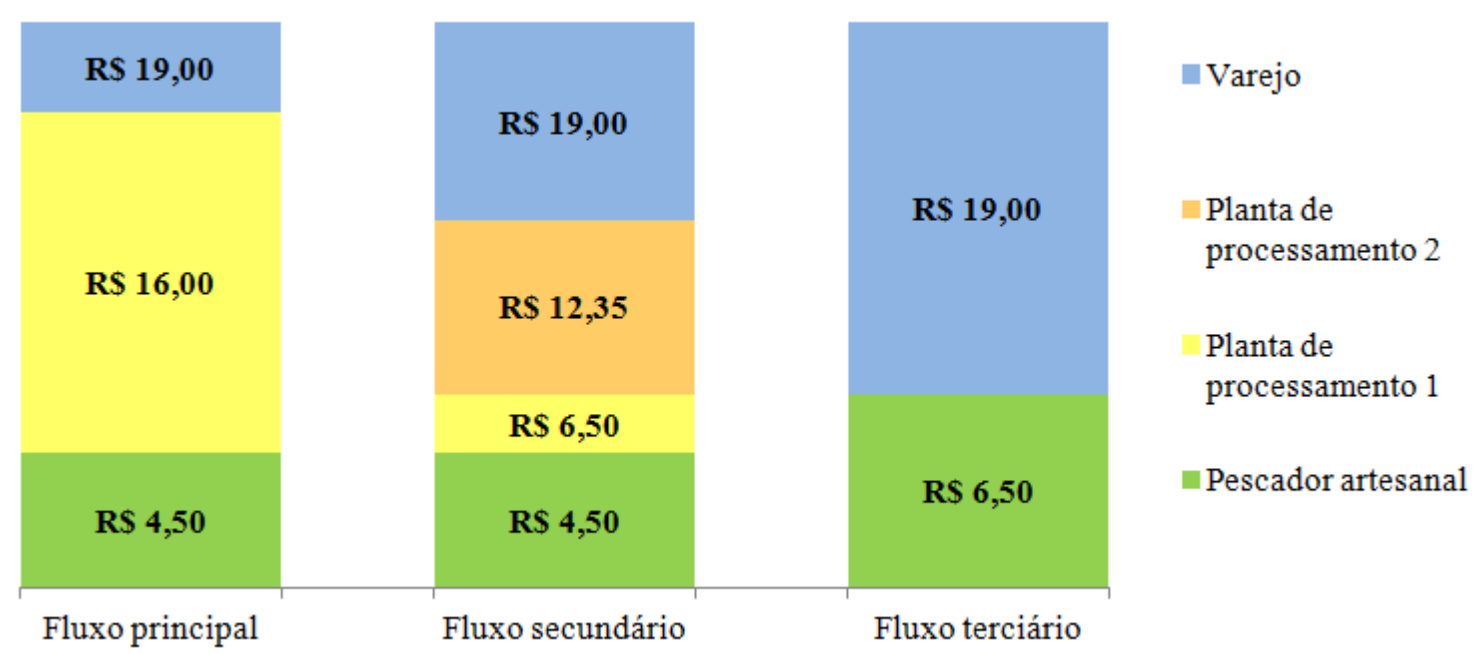

Figura 31 - Diagrama de distribuição dos benefícios acumulados ao longo da cadeia de valor do camarão sete-barbas limpo, referente aos fluxos principal, secundário e terciário. Preços em reais $(\mathrm{R} \$)$, referentes a junho/2013.

\section{Manjuba}

Para cada fluxo de produção da cadeia de valor da manjuba inteira/resfriada, há um diagrama de distribuição dos benefícios acumulados esquematizadas na Figura 32. Mesmo existindo cinco diferentes fluxos de comercialização, o pescador artesanal recebe o mesmo valor da venda do pescado a $\mathrm{R} \$ 2,80 / \mathrm{kg}$. 


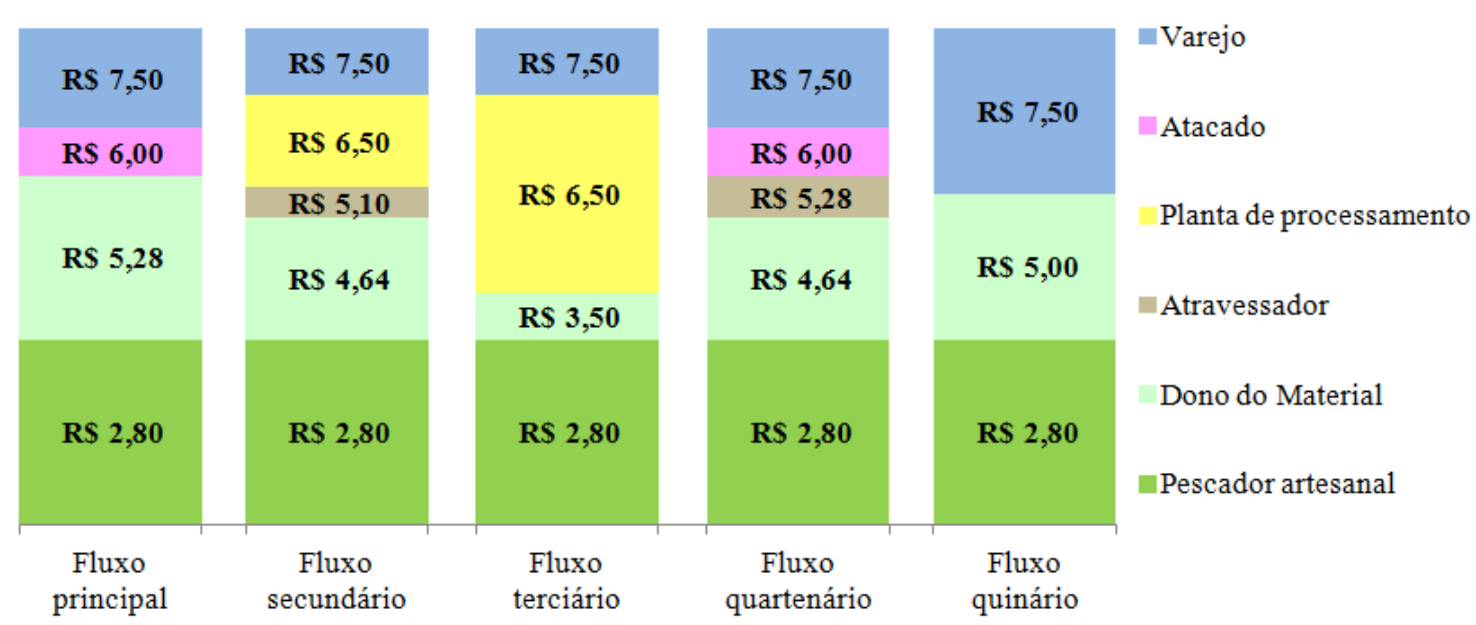

Figura 32 - Diagramas de distribuição dos benefícios ao longo da cadeia de valor da manjuba inteira/resfriada, referente aos fluxos principal, secundário, terciário $\mathrm{e}$ quaternário. Preços em reais (R\$), referentes a junho/2013.

Em quatro fluxos de comercialização, o pescador detém a maior MCB, com exceção do terceiro fluxo. Quando há presença do atravessador, a MCB do dono do material diminui, porém utilizando esse elo, o dono do material consegue escoar toda a produção, que aumenta muito entre os meses de janeiro e março, e para que não tenha prejuízo de descarte, aceita comercializar com o atravessador, mesmo por um valor menor.

Foi elaborado dois diagramas de distribuição dos benefícios acumulados, ambos sobre o fluxo principal da comercialização da manjuba (Figura 33).

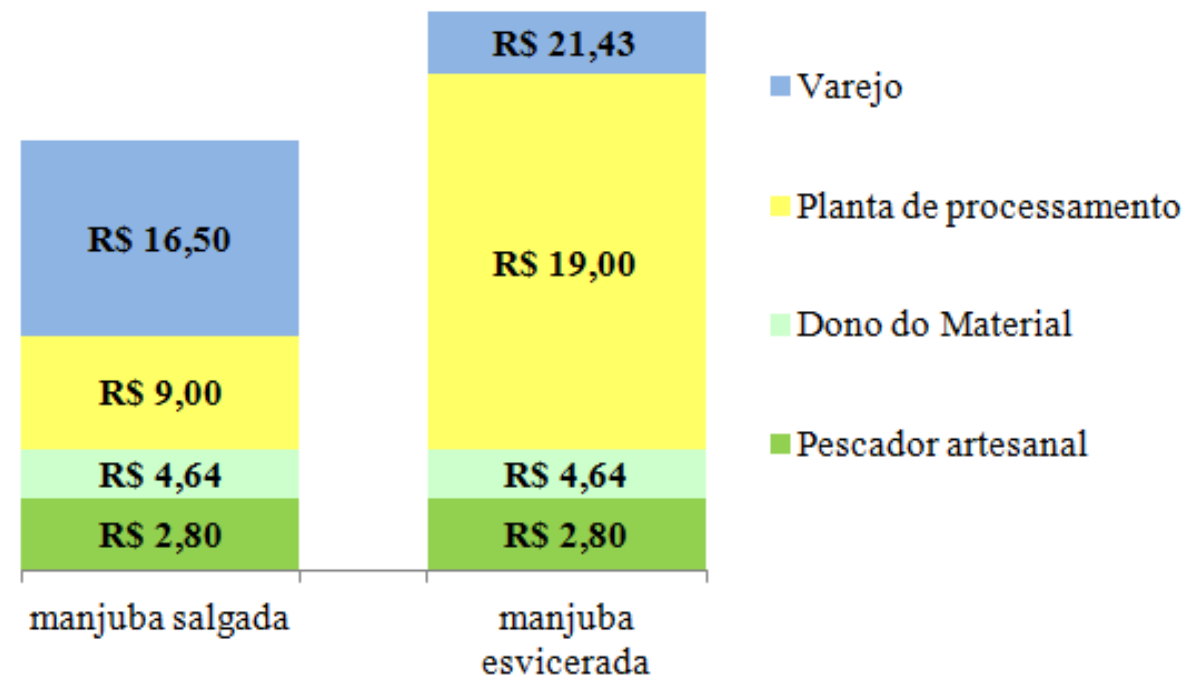

Figura 33 - Diagramas de distribuição dos benefícios acumulados ao longo da cadeia de valor da manjuba salgada e da manjuba eviscerada, referente ao fluxo principal. Preços em reais $(\mathrm{R} \$)$, referentes à fev/2014. 
No caso da comercialização da manjuba salgada, o valor vendido ao consumidor $(\mathrm{R} \$ 16,50)$ é quase seis vezes maior do que o pescador repassa para o dono do material ( $\mathrm{R}$ \$ 2,80). E em relação à comercialização da manjuba eviscerada, o valor vendido ao consumidor $(\mathrm{R} \$ 21,43)$ é um pouco mais que sete vezes e meia maior que o pescador repassa para o dono do material $(\mathrm{R} \$ 2,80)$. O valor de venda da manjuba eviscerada é maior que a manjuba salgada, devido principalmente à utilização da mão de obra especializada, e a alta perda e descarte dos resíduos não aproveitáveis do pescado (cabeça, nadadeiras e vísceras) no processo de filetagem.

\section{Análise comparativa distribuição dos benefícios das cadeias}

A comparação dos diagramas de distribuição dos benefícios acumulados ao longo dos segmentos das cadeias de valores dos produtos corvina inteira/resfriada, camarão sete-barbas limpo e manjuba inteira/resfriada foi esquematizado na Figura 34. $\mathrm{Na}$ cadeia da corvina inteira/resfriada a maior margem de comercialização bruta é do pescador artesanal, e a menor é a do atravessador. No camarão sete-barbas limpo, a maior margem de comercialização bruta é da planta de processamento e o menor é do varejo. E por fim, a maior margem de comercialização bruta da cadeia da manjuba inteira/resfriadoé o do pescador artesanal e a menor é do atacado.

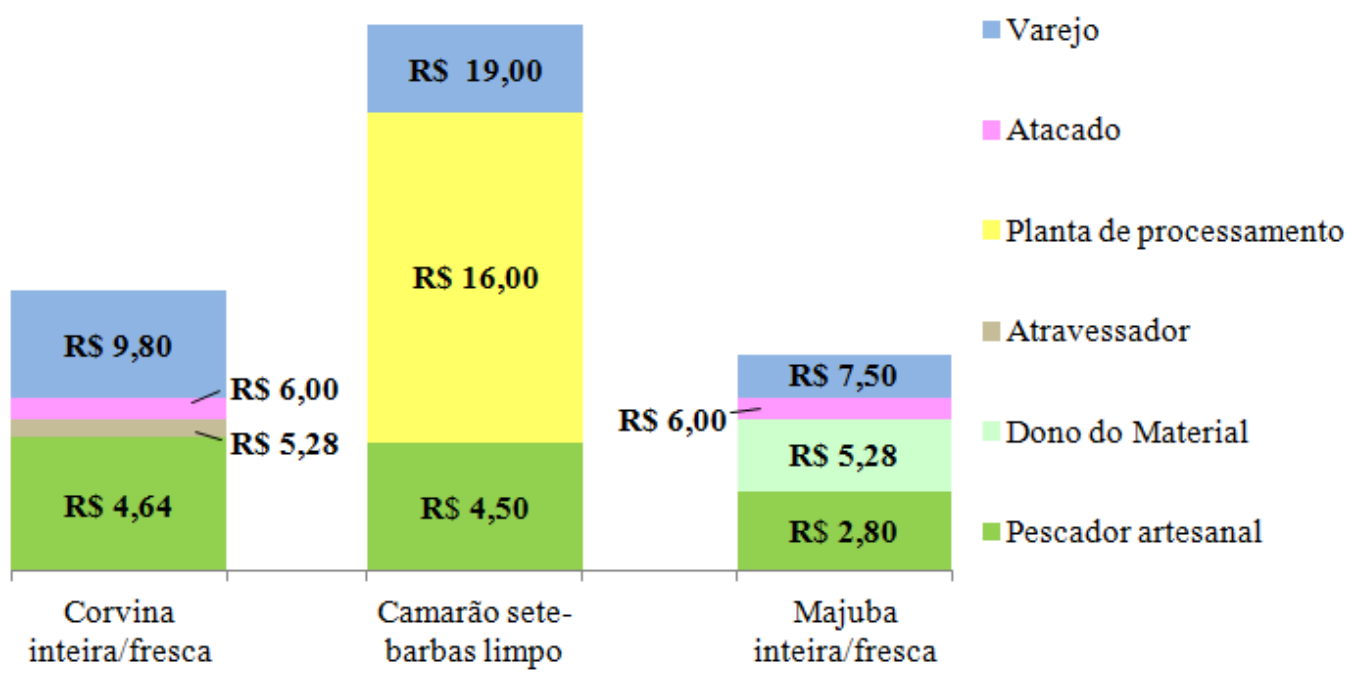

Figura 34 - Comparação dos diagramas de distribuição dos benefícios ao longo da cadeia de valor da corvina inteira/resfriada, do camarão sete-barbas limpo e da manjuba inteira/ resfriada. Preços em reais (R\$), referentes a julho e agosto/2013 para a corvina; junho/2013 para o camarão sete-barbas; e fevereiro/2014 para a manjuba. 
A proporção do valor de comercialização de cada elo comparado ao valor final de venda para os produtos da corvina inteira/resfriada, do camarão sete-barbas limpo e da manjuba inteira/ resfriada, está sintetizada na Tabela 4.

Tabela 4 - Desempenho da proporção do valor de comercialização de cada segmento comparado ao valor final de venda. (NA não se aplica).

\begin{tabular}{c|c|c|c}
\hline \multirow{2}{*}{ Cadeia de valor } & \multicolumn{3}{|c}{ Proporção do valor de comercialização } \\
\cline { 2 - 4 } & $\begin{array}{c}\text { Corvina } \\
\text { inteira/resfriada }\end{array}$ & $\begin{array}{c}\text { Camarão } \\
\text { sete-barbas limpo }\end{array}$ & $\begin{array}{c}\text { Manjuba } \\
\text { inteira/resfriada }\end{array}$ \\
\hline Pescador artesanal & $46,35 \%$ & $23,68 \%$ & $37,33 \%$ \\
\hline Dono de apetrecho & NA & NA & $33,07 \%$ \\
\hline Atravessador & $6,53 \%$ & NA & NA \\
\hline $\begin{array}{c}\text { Planta de } \\
\text { Processamento }\end{array}$ & NA & $60,53 \%$ & NA \\
\hline Atacadista & $7,35 \%$ & NA & $9,60 \%$ \\
\hline Varejista & $38,78 \%$ & $15,79 \%$ & $20,00 \%$ \\
\hline \hline Desempenho & Baixo & Baixo & Médio \\
\hline \hline
\end{tabular}

Nota-se que na presença do elo planta de processamento, este detém a maior parcela da distribuição dos benefícios ao longo da cadeia (camarão sete-barbas limpo), enquanto que nas outras cadeias, que não há presença desse elo de processamento do recurso, o pescador artesanal que detém a maior parcela (corvina inteira/resfriada e manjuba inteira/resfriada).

Portanto, o desempenho em relação à proporção do valor de comercialização de cada segmento foi considerado baixo para as cadeias da corvina inteira/resfriada e do camarão sete-barbas limpo, e médio para a manjuba inteira/resfriada.

\section{Programas Federais}

A participação em programas federais pelos segmentos ao longo das três cadeias produtivas é sintetizada na Tabela 5. Em síntese, os programas implantados foram: a) seguro-defeso (nos sistemas pesqueiros do camarão sete-barbas e da manjuba); b) Plano Safra da Pesca e Aquicultura em relação ao incentivo ao crédito para 
pescadores artesanais (no sistema da corvina); c) Programa de Subvenção Econômica ao Preço do Óleo Diesel (no sistema do camarão sete-barbas).

Tabela 5 - Desempenho dos programas federais implementados nas cadeias de valores. (0 não participa, e NA não se aplica).

\begin{tabular}{|c|c|c|c|c|}
\hline \multirow[b]{2}{*}{$\mathrm{N}^{\mathrm{o}}$} & \multirow[b]{2}{*}{ Programas Federais } & \multicolumn{3}{|c|}{ Cadeia de Valor } \\
\hline & & Corvina & $\begin{array}{c}\text { Camarão } \\
\text { sete-barbas }\end{array}$ & Manjuba \\
\hline 1 & Seguro defeso & NA & $\mathrm{x}$ & $\mathrm{x}$ \\
\hline 2 & Pescando Letras & 0 & 0 & 0 \\
\hline 3 & $\begin{array}{c}\text { PRONATEC Pesca e } \\
\text { Aquicultura }\end{array}$ & 0 & 0 & 0 \\
\hline 4 & Telecentros & 0 & 0 & 0 \\
\hline 5 & $\begin{array}{c}\text { Plano Safra da Pesca e } \\
\text { Aquicultura } \\
\text { 2012/2013/2014 } \\
\text { (incentivo ao crédito) }\end{array}$ & $\mathrm{x}$ & 0 & 0 \\
\hline 6 & $\begin{array}{c}\text { Programa de } \\
\text { Subvenção Econômica } \\
\text { ao Preço do Óleo } \\
\text { Diesel }\end{array}$ & 0 & $\mathrm{x}$ & 0 \\
\hline 7 & Profrota & 0 & 0 & 0 \\
\hline 8 & $\begin{array}{c}\text { Programa de Apoio a } \\
\text { Cadeia Produtiva do } \\
\text { Pescado } \\
\end{array}$ & 0 & 0 & 0 \\
\hline & TOTAL & 1 & 2 & 1 \\
\hline & Desempenho & Baixo & Baixo & Baixo \\
\hline
\end{tabular}

a) O seguro-defeso é fornecido aos pescadores, devidamente registrados como artesanais, através do registro geral da pesca (RGP) do camarão sete-barbas e da manjuba. Para os pescadores do camarão sete barbas, o seguro é referente aos meses de paralisação da pesca (março a maio), e para os pescadores de manjuba beneficiários o seguro é durante o período de piracema (paralisação da atividade pesqueira na bacia hidrográfica visando à proteção dos recursos pesqueiros continentais no período de reprodução). Mesmo a manjuba possuindo um período de defeso próprio de um mês (26/12 - 25/01), os pescadores da Barragem do Valo Grande recebem o seguro defeso de quatro meses (novembro a fevereiro) referente à proibição da pesca em águas 
interiores (o chamado "piracema"), entre os meses de novembro à fevereiro considerado um período de reprodução natural dos peixes, na bacia hidrográfica do Sudeste.

b) O Plano Safra da Pesca e Aquicultura em relação ao incentivo ao crédito é fornecido aos pescadores de corvina de Ubatuba (SP), no qual alguns pescadores e armadores foram beneficiários dos créditos para ampliar e melhorar as embarcações, através dos empréstimos concedidos a juros baixos. Por fim, o Programa de Subvenção Econômica ao Preço do Óleo Diesel é concedido para poucos armadores de embarcações do camarão sete-barbas no Rio do Meio, Guarujá (SP).

Portanto, o desempenho da adesão aos programas públicos federais foi considerado baixo, para as três cadeias estudadas.

\section{Participação do gênero feminino}

A participação da mulher nos segmentos ao longo das cadeias produtivas é sintetizada na Quadro 5. Essa participação foi evidenciada apenas nas plantas de processamento (para o camarão sete-barbas e a manjuba) e no comércio varejista (em todos os casos).

No processamento do camarão sete-barbas, as mulheres possuem um papel fundamental. Em quase $100 \%$ de todas as plantas de processamento na região do Rio do Meio, no Guarujá, o trabalho da mulher foi observado. As mulheres trabalham mediante demanda, e muitas vezes podem trabalhar durante 10 horas seguidas, recebendo por $\mathrm{Kg}$ de camarão processado (descabeçamento do camarão e separação dos grandes e pequenos). $\mathrm{O}$ valor recebido pelo processo de descabeçamento é de $\mathrm{R} \$ 1,50 / \mathrm{Kg}$ e de separação é de $\mathrm{R} \$ 0,60 / \mathrm{Kg}$. Sem contrato de trabalho ou carteira assinada, as "descabeçadeiras" (como são chamadas localmente) trabalham informalmente nesse segmento, e para a maioria delas, esse trabalho é a única forma de renda, na qual podem receber até $\mathrm{R} \$ 1500,00$ por mês, na época de safra do recurso pesqueiro. 
Quadro 5 - Desempenho da participação do gênero feminino em cada cadeia de valor estudada. (0 não participa, e NA não se aplica).

\begin{tabular}{c|c|c|c}
\hline \multirow{2}{*}{ Atores } & \multicolumn{3}{|c}{ Cadeia de Valor } \\
\cline { 2 - 4 } & Corvina & $\begin{array}{c}\text { Camarão } \\
\text { sete- } \\
\text { barbas }\end{array}$ & Manjuba \\
\hline $\begin{array}{c}\text { Pescador } \\
\text { artesanal }\end{array}$ & 0 & 0 & 0 \\
\hline $\begin{array}{c}\text { Dono de } \\
\text { apetrecho }\end{array}$ & NA & NA & 0 \\
\hline $\begin{array}{c}\text { Atravessador } \\
\text { Planta de } \\
\text { Processamento }\end{array}$ & 0 & NA & 0 \\
\hline Atacadista & 0 & Alto & Médio \\
\hline Varejista & Baixo & Baixo & Baixo \\
\hline \hline Desempenho & Baixo & Médio & Baixo \\
\hline \hline
\end{tabular}

$\mathrm{Na}$ cadeia produtiva da manjuba, a participação do gênero feminino foi observada no beneficiamento, na planta de processamento de salga. A atividade desenvolvida é a da montagem das bandejas com manjubas já salgadas para a comercialização. Estas, ao contrário das descabeçadeiras, possuem carteiras de trabalho assinadas e direitos trabalhistas assegurados.

No comércio varejo, das três cadeias de valores, foram encontradas mulheres trabalhando tanto na atividade de venda do produto, assim como proprietária de estabelecimentos. Mas a participação é baixa, comparada com o número homens nesse segmento. Portanto, o desempenho em relação a participação da mulher na cadeia foi considerado baixo para as cadeias da corvina e da manjuba, e médio para o camarão sete-barbas. 


\subsubsection{Eficiência}

\section{Valor da pescaria}

Os valores das pescarias da corvina, do camarão sete-barbas e da manjuba estão descritas na Tabela 6. Nota-se que a manjuba possui o maior valor da pescaria, mesmo possuindo o menor valor de comercialização por $\mathrm{kg}$, justificável pela alta produção de pescado durante o período da safra.

Tabela 6 - Valor mediano das pescarias no período da safra de 2013. Valores em real $(\mathrm{R} \$)$, referentes a 2013.

\begin{tabular}{|c|c|c|c|c|c|c|}
\hline \multirow{3}{*}{$\begin{array}{l}\text { Sistema } \\
\text { pesqueiro }\end{array}$} & \multicolumn{6}{|c|}{ Valor mediano da pescaria } \\
\hline & \multirow{2}{*}{$\begin{array}{l}\text { Período de } \\
\text { referência }\end{array}$} & \multirow{2}{*}{$\begin{array}{c}\text { Produção } \\
\text { total média } \\
\text { na safra } \\
(\mathrm{kg}) \\
\end{array}$} & \multicolumn{3}{|c|}{$\begin{array}{c}\text { Preço do pescado na safra } \\
(\mathrm{R} \$ / \mathrm{kg})\end{array}$} & \multirow{2}{*}{$\begin{array}{l}\text { Valor total } \\
\text { da pescaria } \\
(\mathrm{R} \$)\end{array}$} \\
\hline & & & Menor & Maior & Mediana & \\
\hline Corvina & $\begin{array}{c}\text { março a agosto } \\
\text { de } 2013\end{array}$ & $354.862,90$ & 6,0 & 10,0 & 8,0 & $2.838 .930,20$ \\
\hline $\begin{array}{c}\text { Camarão } \\
\text { sete- } \\
\text { barbas }\end{array}$ & $\begin{array}{c}\text { junho a } \\
\text { setembro } \\
\text { de } 2013 \\
\end{array}$ & $405.245,30$ & 8,0 & 9,0 & 8,5 & $3.444 .585,05$ \\
\hline Manjuba & $\begin{array}{l}\text { outubro de } 2013 \\
\text { a março de } 2014\end{array}$ & $693.959,24$ & 5,0 & 6,0 & 5,5 & $3.816 .775,82$ \\
\hline
\end{tabular}

\section{Infraestrutura}

A infraestrutura de armazenamento, distribuição e comercialização nos segmentos ao longo das cadeias produtivas são apresentadas no Quadro 6.

No segmento de produção da manjuba não foi encontrado nenhuma infraestrutura essencial, tal como píer para o desembarque do pescado ou gelo acessível para resfriar e manter a qualidade do pescado até o próximo elo.

O transporte com caminhão frigorífico foi identificado no segmento de atravessador tanto na cadeia da corvina como da manjuba, porém a diferença é que para a corvina, há disponibilidade de gelo, uma vez que o pescado capturado é enviado diretamente ao atacado, enquanto que para a manjuba, o atravessador e o dono do apetrecho armazena a captura até obter um volume ótimo para enviar para o atacado. 
Quadro 6 - Desempenho das infraestruturas de armazenamento, distribuição e comercialização existentes nos segmentos da cadeia de valor. (0 não participa, e NA não se aplica).

\begin{tabular}{|c|c|c|c|c|}
\hline \multirow[b]{2}{*}{$\mathrm{N}^{\mathrm{o}}$} & \multirow[b]{2}{*}{ Atores } & \multicolumn{3}{|c|}{ Cadeia de Valor } \\
\hline & & Corvina & $\begin{array}{c}\text { Camarão sete- } \\
\text { barbas }\end{array}$ & Manjuba \\
\hline 1 & $\begin{array}{l}\text { Pescador } \\
\text { artesanal }\end{array}$ & $\begin{array}{c}\text { - Píer de } \\
\text { desembarque } \\
\text { - Gelo acessível }\end{array}$ & $\begin{array}{c}\text { - Píer de } \\
\text { desembarque } \\
\text { - Gelo acessível }\end{array}$ & 0 \\
\hline 2 & Atravessador & $\begin{array}{c}\text { - Gelo acessível } \\
\text { - Transporte com } \\
\text { caminhão } \\
\text { frigorífico }\end{array}$ & NA & $\begin{array}{l}\text { - Armazenamento } \\
\text { adequado (câmera } \\
\text { fria / freezer) } \\
\text { - Transporte com } \\
\text { caminhão frigorífico }\end{array}$ \\
\hline 3 & $\begin{array}{c}\text { Planta de } \\
\text { processamento }\end{array}$ & NA & $\begin{array}{l}\text { - Armazenamento } \\
\text { adequado (câmera } \\
\text { fria / freezer) } \\
\text { - Maquinários } \\
\text { apropriados } \\
\text { - Transporte com } \\
\text { caminhão } \\
\text { frigorífico } \\
\text { - Gelo acessível }\end{array}$ & $\begin{array}{c}\text { - Armazenamento } \\
\text { adequado (câmera } \\
\text { fria / freezer) } \\
\text { - Maquinários } \\
\text { apropriados } \\
\text { - Transporte com } \\
\text { caminhão frigorífico } \\
\text { - Gelo acessível }\end{array}$ \\
\hline 4 & Atacadista & $\begin{array}{l}\text { Armazenamento } \\
\text { adequado (câmera } \\
\text { fria / freezer) }\end{array}$ & NA & $\begin{array}{l}\text { Armazenamento } \\
\text { adequado (câmera } \\
\text { fria / freezer) }\end{array}$ \\
\hline 5 & Varejista & $\begin{array}{l}\text { - Armazenamento } \\
\text { adequado (câmera } \\
\text { fria / freezer) } \\
\text { - Transporte com } \\
\text { caminhão } \\
\text { frigorífico }\end{array}$ & $\begin{array}{l}\text { - Armazenamento } \\
\text { adequado (câmera } \\
\text { fria / freezer) } \\
\text { - Transporte com } \\
\text { caminhão } \\
\text { frigorífico }\end{array}$ & $\begin{array}{l}\text { - Armazenamento } \\
\text { adequado (câmera } \\
\text { fria / freezer) } \\
\text { - Transporte com } \\
\text { caminhão frigorífico }\end{array}$ \\
\hline & TOTAL & 7 de $14(50 \%)$ & 8 de $12(63 \%)$ & 9 de $18(50 \%)$ \\
\hline & esempenho & Médio & Médio & Médio \\
\hline
\end{tabular}

O desempenho das infraestruturas necessárias para o armazenamento, distribuição e comercialização do pescado foi considerado médio para as três cadeias estudadas. 


\section{Valor agregado ao produto}

Os elos que agregam valor ao produto por meio do processamento (salga, filetagem, limpeza ou descabeçamento) ao longo das cadeias de valores são descritas na Tabela 7.

As cadeias de valores do camarão sete-barbas e da manjuba, por possuírem o processador (plantas de processamento), possuem mais atores que agregam valor ao produto, e dessa forma, conseguem elevar o valor de venda do pescado, tendo a opção de produtos diversificados além do inteiro/fresco.

No varejo, em todas as cadeias, pode existir algum beneficiamento do produto, seja a filetagem, a limpeza, o descabeçamento como também a manipulação do pescado em refeições servidas em restaurantes.

Tabela 7 - Desempenho do número de elos que agregam valor ao produto através do beneficiamento. (0 não participa, e NA não se aplica).

\begin{tabular}{c|c|c|c}
\hline \multirow{2}{*}{ Elos } & \multicolumn{3}{|c}{ Cadeia de Valor } \\
\cline { 2 - 4 } & Corvina & $\begin{array}{c}\text { Camarão } \\
\text { sete-barbas }\end{array}$ & Manjuba \\
\hline Pescador artesanal & 0 & 0 & 0 \\
\hline Dono do apetrecho & NA & NA & 0 \\
\hline Atravessador & 0 & NA & 0 \\
\hline $\begin{array}{c}\text { Planta de } \\
\text { Processamento }\end{array}$ & 0 & $\mathrm{x}$ & $\mathrm{x}$ \\
\hline Atacadista & 0 & $\mathrm{NA}$ & 0 \\
\hline Varejista & $\mathrm{x}$ & $\mathrm{x}$ & $\mathrm{x}$ \\
\hline TOTAL & 1 & 2 & 2 \\
\hline \hline Desempenho & Baixo & Médio & Baixo \\
\hline \hline
\end{tabular}

Os preços de comercialização no varejo dos recursos pesqueiros que são processados pelas plantas de processamento, na cadeia produtiva tanto do camarão setebarbas, que é processado limpo e descabeçado, e da manjuba, que é processada salgada e eviscerada, são representados na Tabela 8. A manjuba eviscerada apresentou o maior 
valor de venda entre os produtos processados comparados entre as três cadeias de produtivas, seguido do camarão sete-barbas limpo.

Tabela 8 - Comparação dos preços de comercialização no varejo dos recursos processados. Valores referentes aos períodos safras dos recursos.

\begin{tabular}{c|c|c|c|c}
\hline \hline \multirow{2}{*}{$\begin{array}{c}\text { Preço de comercialização } \\
\text { no varejo }\end{array}$} & $\begin{array}{c}\text { Camarão } \\
\text { sete-barbas } \\
\text { limpo }\end{array}$ & $\begin{array}{c}\text { Camarão } \\
\text { sete-barbas } \\
\text { descabeçado }\end{array}$ & $\begin{array}{c}\text { Manjuba } \\
\text { salgada }\end{array}$ & $\begin{array}{c}\text { Manjuba } \\
\text { eviscerada }\end{array}$ \\
\hline \multirow{2}{*}{$(\mathrm{R} \$ / \mathrm{kg})$} & 19,00 & 16,50 & 16,50 & 21,43 \\
\hline
\end{tabular}

Assim, o desempenho do valor agregado ao recurso pesqueiro foi baixo para o cadeia da corvina e da manjuba, enquanto que o camarão sete-barbas o desempenho foi baixo.

\section{Deficiências e entraves}

As principais deficiências e entraves levantados juntos aos atores das cadeias de valores e a quantidade de vezes que foram citadas constam na Tabela 9.

Tabela 9 - Deficiências e entraves levantados pelos representantes (atores da cadeia de valor) e o número de citações de cada item.

\begin{tabular}{|c|c|c|c|c|}
\hline \multirow[b]{2}{*}{ Item } & \multirow[b]{2}{*}{ Deficiências e entraves } & \multicolumn{3}{|c|}{ Cadeia de Valor } \\
\hline & & Corvina & $\begin{array}{c}\text { Camarão } \\
\text { sete-barbas }\end{array}$ & Manjuba \\
\hline 1 & $\begin{array}{l}\text { Deficiência de infraestrutura de } \\
\text { desembarque, armazenamento, } \\
\text { transporte e venda }\end{array}$ & 4 & 0 & 4 \\
\hline 2 & $\begin{array}{l}\text { Baixa inclusão do pescado nos } \\
\text { programas institucionais }\end{array}$ & 1 & 0 & 0 \\
\hline 3 & $\begin{array}{l}\text { Escassez de linhas de financiamento } \\
\text { destinadas ao setor pesqueiro }\end{array}$ & 1 & 0 & 0 \\
\hline 4 & $\begin{array}{l}\text { Falta ou baixa oportunidade de } \\
\text { agregar valor ao pescado }\end{array}$ & 0 & 1 & 1 \\
\hline
\end{tabular}


(continuação da Tabela 9 - Deficiências e entraves levantados pelos representantes...)

\begin{tabular}{|c|c|c|c|c|}
\hline \multirow[b]{2}{*}{ Item } & \multirow[b]{2}{*}{ Deficiências e entraves } & \multicolumn{3}{|c|}{ Cadeia de Valor } \\
\hline & & Corvina & $\begin{array}{c}\text { Camarão } \\
\text { sete-barbas }\end{array}$ & Manjuba \\
\hline 5 & Pesca e comércio ilegal & 7 & 2 & 4 \\
\hline 6 & $\begin{array}{l}\text { Baixa efetividade dos serviços de } \\
\text { assistência técnica }\end{array}$ & 1 & 1 & 0 \\
\hline 7 & Condições precárias de trabalho & 0 & 2 & 3 \\
\hline 8 & $\begin{array}{l}\text { Fraca organização da cadeia } \\
\text { produtiva }\end{array}$ & 0 & 3 & 3 \\
\hline 9 & $\begin{array}{l}\text { Embarcações e maquinário } \\
\text { sucateados e tecnologias de } \\
\text { beneficiamento inadequadas }\end{array}$ & 0 & 1 & 0 \\
\hline 10 & $\begin{array}{l}\text { Elevada dependência do sistema de } \\
\text { atravessadores e baixa confiabilidade } \\
\text { para comercialização do pescado }\end{array}$ & 1 & 0 & 2 \\
\hline 11 & Falta de mão de obra especializada & 1 & 2 & 0 \\
\hline 12 & Redução dos estoques pesqueiros & 1 & 1 & 2 \\
\hline 13 & $\begin{array}{l}\text { Aumento de competividade no } \\
\text { segmento }\end{array}$ & 1 & 1 & 3 \\
\hline 14 & $\begin{array}{l}\text { Medidas técnicas de proteção do } \\
\text { recurso e do ecossistema erradas }\end{array}$ & 1 & 4 & 0 \\
\hline 15 & $\begin{array}{l}\text { Dificuldades em obter documentos } \\
\text { necessários para a pesca e } \\
\text { comercialização }\end{array}$ & 7 & 1 & 1 \\
\hline 16 & $\begin{array}{l}\text { Baixa operacionalização dos órgãos } \\
\text { de fiscalização }\end{array}$ & 4 & 5 & 1 \\
\hline 17 & $\begin{array}{l}\text { Desvalorização do pescado no } \\
\text { mercado }\end{array}$ & 2 & 1 & 0 \\
\hline 18 & $\begin{array}{l}\text { Falta de atendimento aos requisitos } \\
\text { legais e os requisitos de qualidade }\end{array}$ & 0 & 0 & 1 \\
\hline & TOTAL & 13 & 13 & 11 \\
\hline & Conclusão do desempenho & Baixo & Baixo & Baixo \\
\hline
\end{tabular}

Das 18 deficiências apresentadas no questionário, cinco foram apontados pelos atores dos segmentos nas três cadeias de valores: pesca e comércio ilegal, redução dos estoques pesqueiros, aumento de competividade no segmento, dificuldades em obter 
documentos necessários para a pesca e comercialização, e baixa operacionalização dos órgãos de fiscalização. Esses entraves foram apontados principalmente pelos atores dos segmentos de produção (pescador artesanal, e donos de apetrecho) e dos atravessadores.

A pesca e o comércio ilegal e as dificuldades em obter documentos necessários para a pesca e comercialização foram os entraves mais apontados pelos atores da cadeia de valor da corvina. Baixa operacionalização dos órgãos de fiscalização foi apontado como o principal entrave na cadeia do camarão sete-barbas. Enquanto que deficiência de infraestrutura de desembarque, armazenamento, transporte e venda, e pesca e comércio ilegal foram apontados na cadeia da manjuba.

A conclusão do desempenho sobre as deficiências e entraves levantados foi considerada baixa para todas cadeias estudadas.

\section{Regulamentação e Ordenamento da pesca}

As regulamentações e ordenamentos identificados nas três pescarias, descritos no Quadro 8, foram nove: três referentes a autorizações (para a atividade de pesca, permissão para pescar o recurso), quatro referentes às medidas técnicas (limitações do apetrecho, época de defeso, áreas de proibição de pesca e tamanho mínimo de captura), um referente ao controle de bycatch, e dois referentes aos subsídios (seguro defeso e redução do valor do óleo diesel).

As autorizações para a atividade de pesca, limitações do apetrecho, período e áreas de proibição da pesca estão presentes nos três sistemas pesqueiros. Em contrapartida, o tamanho mínimo de captura é aplicado somente para a corvina, e o uso de dispositivo para controle do bycatch e o subsídio no valor do óleo diesel são aplicados somente na pescaria do camarão sete-barbas. As medidas técnicas são as políticas mais adotadas nos três sistemas pesqueiros, seguido das autorizações de pesca e subsídios. Todas essas medidas de manejo estão descritas em requisitos legais e passíveis de penalidades uma vez que não são cumpridas.

Assim, o indicador de regulamentações e ordenamento da pesca implementadas nos sistemas pesqueiros estudados apresentou um desempenho médio para todos os sistemas. 
Quadro 8 - Desempenho das regulamentações e ordenamento aplicados ao sistema pesqueiro. (0 não participa).

\begin{tabular}{|c|c|c|c|}
\hline \multirow{2}{*}{$\begin{array}{c}\text { Regulamentações } \\
\text { e ordenamento }\end{array}$} & \multicolumn{3}{|c|}{ Sistema pesqueiro } \\
\hline & Corvina & Camarão sete-barbas & Manjuba \\
\hline \multirow{2}{*}{$\begin{array}{l}\text { Permissionamento } \\
\text { /Autorizações }\end{array}$} & $\begin{array}{l}\text { Autorização para a atividade de } \\
\text { pesca: carteira de pescador } \\
\text { artesanal. (IN N }{ }^{\circ} 02 / 2011 \text { ) }\end{array}$ & $\begin{array}{l}\text { Autorização para a atividade de } \\
\text { pesca: carteira de pescador artesanal. } \\
\text { (IN N } 02 / 2011 \text { ) }\end{array}$ & \multirow{2}{*}{$\begin{array}{l}\text { Autorização para a atividade } \\
\text { de pesca: carteira de pescador } \\
\text { artesanal. } \\
\text { (IN N }{ }^{\circ} 02 / 2011 \text { ) }\end{array}$} \\
\hline & $\begin{array}{l}\text { Permissão para pescar o recurso: } \\
\text { licença para capturar o recurso. } \\
\text { (IN N } 135 / 2006)\end{array}$ & $\begin{array}{l}\text { Permissão para pescar o recurso: } \\
\text { licença para capturar o recurso. } \\
\text { (IN N } 18 / 2007 \text { ) }\end{array}$ & \\
\hline \multirow{2}{*}{ Medidas técnicas } & $\begin{array}{l}\text { Limitações do apetrecho: } \\
\text { dependente da AB do barco há } \\
\text { limitações no comprimento } \\
\text { máximo e altura das redes de } \\
\left.\text { emalhe. (IN N }{ }^{\circ} 12 / 2012\right)\end{array}$ & $\begin{array}{l}\text { Limitações do apetrecho: controle da } \\
\text { malhagem mínima da rede. } \\
(\text { IN N } 03 / 2011 \text { ) }\end{array}$ & $\begin{array}{l}\text { Limitações do apetrecho: } \\
\text { controle do comprimento } \\
\text { máximo e da malhagem } \\
\text { mínima da rede. } \\
\text { (IN No } 33 / 2004)\end{array}$ \\
\hline & $\begin{array}{l}\text { Período de proibição de pesca: } \\
\text { 15/05 - 15/06 para } \\
\text { embarcações maiores de 20AB. } \\
\text { (IN N }{ }^{\circ} 12 / 2012 \text { ) }\end{array}$ & $\begin{array}{l}\text { Período de proibição de pesca: } \\
\text { 01/março - 31/maio. } \\
\text { (IN N } \text { N }^{\circ} \text { 189/2008) }\end{array}$ & $\begin{array}{l}\text { Período de proibição de } \\
\text { pesca: } 26 / \text { dez }-25 / \text { jan. } \\
\text { (IN N } 195 / 2008 \text { ) }\end{array}$ \\
\hline
\end{tabular}


(continuação - Quadro 8 - Desempenho das regulamentações e ordenamento aplicados ao sistema pesqueiro...)

\begin{tabular}{|c|c|c|c|}
\hline \multirow{2}{*}{$\begin{array}{l}\text { Regulamentações e } \\
\text { ordenamento }\end{array}$} & \multicolumn{3}{|c|}{ Sistema pesqueiro } \\
\hline & Corvina & Camarão sete-barbas & Manjuba \\
\hline & $\begin{array}{l}\text { Áreas de proibição de pesca: } \\
\text { distancia de três milhas } \\
\text { náuticas da costa. (IN N } \\
\text { 12/2012) }\end{array}$ & $\begin{array}{l}\text { Áreas de proibição de pesca: para } \\
\text { embarcações de arrasto maiores que } \\
10 \mathrm{AB} \text {, a menos de } 1,5 \text { milhas } \\
\text { náuticas da costa nas áreas costeiras } \\
\text { do estado de São Paulo. (Portaria } \\
\text { SUDEPE N } 54 N / 1984 \text { ) }\end{array}$ & $\begin{array}{l}\text { Áreas de proibição de } \\
\text { pesca: Canal do Valo } \\
\text { Grande, após barragem. } \\
\text { (IN N }{ }^{\circ} 33 / 2004 \text { ) }\end{array}$ \\
\hline & $\begin{array}{l}\text { Tamanho mínimo de captura: } \\
25 \mathrm{~cm} \text {. (IN No } 53 / 2005 \text { ) }\end{array}$ & $\begin{array}{l}\text { Embarcação: limitação do tamanho } \\
\text { do barco e poder de pesca. (IN N } \\
\text { 03/2011) }\end{array}$ & - \\
\hline $\begin{array}{l}\text { Controle de } \\
\text { bycatch }\end{array}$ & - & $\begin{array}{l}\text { Proteção ecossistêmica: uso } \\
\text { obrigatório do Dispositivo de } \\
\text { Escape de Tartarugas (TED) para } \\
\text { embarcações com comprimento } \\
\text { superior a } 11 \text { metros. } \\
\left(\text { IN N }^{\circ} 31 / 2004\right)\end{array}$ & - \\
\hline
\end{tabular}


(continuação - Quadro 8 - Desempenho das regulamentações e ordenamento aplicados ao sistema pesqueiro...)

\begin{tabular}{cccc}
\hline \hline $\begin{array}{c}\text { Regulamentações } \\
\text { e ordenamento }\end{array}$ & Corvina & Camarão sete-barbas & Manjuba \\
\cline { 2 - 4 } $\begin{array}{c}\text { Subsídios } \\
\text { econômicos }\end{array}$ & - & $\begin{array}{l}\text { Seguro defeso } \\
(\text { LEI No } 10.779 / 2003)\end{array}$ & $\begin{array}{c}\text { Seguro defeso } \\
\left(\text { LEI N }^{\circ} 10.779 / 2003\right)\end{array}$ \\
\cline { 3 - 4 } & 6 & $\begin{array}{l}\text { Redução do valor do óleo diesel } \\
(\text { LEI No } 9.445 / 1997)\end{array}$ & 5 \\
\hline \hline
\end{tabular}




\subsubsection{Empoderamento}

\section{Organizações representativas}

As organizações representativas identificadas nas três cadeias de valores estão descritos na Tabela 10. Os pescadores e donos de embarcações das três cadeias são representados pelas respectivas colônias de pescadores Z10 Ministro Fernando Costa, em Ubatuba; Z1 José Bonifácio, em Santos; e Z7 Veiga Miranda, em Iguape. Essas colônias são regulamentadas pela LEI No 11.699/2008.

Os atacadistas, do CEASA (SP) e CEASA (RJ), da cadeia da corvina e da manjuba são representados pelos sindicatos do comércio atacadista de pescados de São Paulo (SINCOMAT) e do Rio de Janeiro (SINECAAERJ), ambos regulares e atuantes.

Tabela 50 - Desempenho das organizações representativas por elos das cadeias de valores. (0 não participa, e NA não se aplica).

\begin{tabular}{|c|c|c|c|c|}
\hline \multirow[b]{2}{*}{ Atores } & \multirow{2}{*}{$\begin{array}{l}\text { Organizações } \\
\text { representativas }\end{array}$} & \multicolumn{3}{|c|}{ Cadeia de valor } \\
\hline & & Corvina & $\begin{array}{c}\text { Camarão } \\
\text { sete-barbas }\end{array}$ & Manjuba \\
\hline \multirow{4}{*}{$\begin{array}{l}\text { Pescador } \\
\text { artesanal }\end{array}$} & Colônia de Pesca & $\mathrm{x}$ & $\mathrm{x}$ & $\mathrm{x}$ \\
\hline & Associação de Pesca & 0 & 0 & 0 \\
\hline & Cooperativa & 0 & 0 & 0 \\
\hline & Sindicato de Pescadores & 0 & 0 & 0 \\
\hline Atravessador & NA & NA & NA & NA \\
\hline $\begin{array}{c}\text { Planta de } \\
\text { Processamento }\end{array}$ & $\begin{array}{l}\text { Sindicato de Armadores e } \\
\text { Indústrias }\end{array}$ & 0 & 0 & 0 \\
\hline Atacadista & $\begin{array}{l}\text { Sindicato do Comércio } \\
\text { Atacadista de Pescados } \\
\text { (CEAGESP e CEASARJ) }\end{array}$ & $\mathrm{x}$ & NA & $\mathrm{X}$ \\
\hline Varejista & $\begin{array}{c}\text { Associação de } \\
\text { estabelecimentos varejistas }\end{array}$ & 0 & 0 & 0 \\
\hline \multicolumn{2}{|r|}{ TOTAL } & 2 & 1 & 2 \\
\hline \multicolumn{2}{|r|}{ Desempenho } & Baixo & Baixo & Baixo \\
\hline
\end{tabular}


Apesar de existir sindicatos de pescadores e sindicatos de armadores e indústrias no Estado de São Paulo, os atores das cadeias declararam não participar desses sindicatos. Nas três cadeias não existem associações e cooperativas de pesca, e associação de estabelecimentos varejistas.

O desempenho das organizações representativas, nas três cadeias de valores estudas foi considerado baixo.

\section{Relações de trabalho}

As relações de trabalho nos segmentos ao longo das cadeias de valores são apresentadas no Quadro 9. As relações de trabalho encontradas foram: sistemas de partilha (PAR), comissão (COM), autônomo (AUT) e carteira assinada (CAS).

No segmento produtivo, nas três cadeias de valores há sistema de partilha (ou partes) para dividir o lucro entre os envolvidos. Na pescaria da corvina, a partilha é feita semelhante à pescaria do camarão sete-barbas: primeiramente retira-se do lucro obtido após a venda da captura $10 \%$ para o custo de manutenção da embarcação, depois $50 \%$ para o dono da embarcação (em alguns poucos casos, o dono é o mestre da embarcação), e o restante é dividido pelo sistema de cotas no qual o mestre recebe a maior cota (3/4) e a tripulação recebe igualitariamente o restante. Na pescaria da manjuba, a partilha é feita igualitária entre os pescadores das canoas (1/3).

O atravessador recebe através de comissão da venda, pois nesse caso, o papel do atravessador é facilitar a venda da captura entre o produtor (pescador ou dono da embarcação) para o próximo segmento (planta de processamento ou atacadista). A porcentagem da comissão da venda varia entre 10 - $15 \%$ do valor vendido.

No atacado, seja no CEASA de São Paulo como do Rio de Janeiro, o dono da empresa e colaboradores são comissionários, recebendo uma porcentagem pela venda realizada. A comissão da empresa varia de $12-15 \%$, sendo que desse, o vendedor recebe 5\%. Nos estabelecimentos varejistas foi constatado que todos os funcionários são registrados, uma vez que a maioria desses locais são grandes supermercados, sendo a política de contratação a carteira assinada. 
Quadro 9 - Relações de trabalho nos segmentos identificados nas cadeias de valores. Sistema de partilha (PAR), comissão (COM), autônomo (AUT); carteira assinada (CAS) (NA não se aplica).

\begin{tabular}{|c|c|c|c|}
\hline \multirow[b]{2}{*}{ Atores } & \multicolumn{3}{|c|}{ Cadeia de valor } \\
\hline & Corvina & $\begin{array}{l}\text { Camarão } \\
\text { sete-barbas }\end{array}$ & Manjuba \\
\hline $\begin{array}{l}\text { Pescadores } \\
\text { artesanais }\end{array}$ & PAR & PAR & PAR e AUT \\
\hline $\begin{array}{c}\text { Dono de } \\
\text { apetrechos }\end{array}$ & NA & NA & AUT \\
\hline Atravessador & $\mathrm{COM}$ & $\mathrm{COM}$ & $\mathrm{COM}$ \\
\hline $\begin{array}{c}\text { Planta de } \\
\text { Processamento }\end{array}$ & NA & CAS e AUT & CAS \\
\hline Atacadista & $\mathrm{COM}$ & NA & $\mathrm{COM}$ \\
\hline Varejista & CAS & CAS & CAS \\
\hline TOTAL & $\begin{array}{l}\text { PAR, COM } \\
\text { e CAS }\end{array}$ & $\begin{array}{l}\text { PAR, COM, } \\
\text { AUT e CAS }\end{array}$ & $\begin{array}{l}\text { PAR, AUT, } \\
\text { COM e CAS }\end{array}$ \\
\hline
\end{tabular}

\section{Atravessadores}

A dependência dos pescadores artesanais e donos de embarcação aos atravessadores na comercialização da captura estão representados na Tabela 11.

Nota-se que a dependência dos pescadores da cadeia da corvina é acima da média, ou seja, mais da metade dos produtores dependem exclusivamente do atravessador para comercializar a captura. No caso da dependência dos produtores da cadeia da manjuba para comercializar o pescado, é baixa, inclusive refletindo na quantidade desse ator (há somente um atravessador que participa na cadeia, da região estudada).

Assim, o desempenho para esse parâmetro indicativo foi considerado médio para a cadeia da corvina, e alto para a cadeia da manjuba. 
Tabela 11 - Desempenho da dependência do pescador ao atravessador. (NA não se aplica).

\begin{tabular}{c|c|c|c}
\hline \hline \multirow{2}{*}{ Ator } & \multicolumn{3}{|c}{ Cadeia de valor } \\
\cline { 2 - 4 } & Corvina & $\begin{array}{c}\text { Camarão } \\
\text { sete- } \\
\text { barbas }\end{array}$ & Manjuba \\
\hline $\begin{array}{c}\text { Pescador } \\
\text { artesanal }\end{array}$ & $52 \%$ & NA & $29 \%$ \\
\hline \hline Desempenho & Médio & NA & Alto \\
\hline \hline
\end{tabular}

\section{Decisão de comercialização}

O poder de decisão da comercialização do recurso pesqueiro do segmento produtivo representado na Tabela 12.

Tabela 12 - Desempenho da ocorrência dos produtores e intermediários no poder de decisão da comercialização do pescado.

\begin{tabular}{c|c|c|c}
\hline \multirow{2}{*}{ Atores } & \multicolumn{3}{|c}{ Cadeia de valor } \\
\cline { 2 - 4 } & Corvina & $\begin{array}{c}\text { Camarão } \\
\text { sete-barbas }\end{array}$ & Manjuba \\
\hline Produtores & $14,3 \%$ & $50,9 \%$ & $7,7 \%$ \\
\hline \hline Desempenho & Baixo & Médio & Baixo \\
\hline \hline
\end{tabular}

Nas três cadeias de valores, o segmento produtivo há claramente uma falta de escolha para a comercialização do recurso, tanto para a cadeia da corvina, e principalmente da manjuba. Ou seja, esses produtores não escolhem o intermediário que vai comercializar o pescado, baseado no melhor preço ou por confiança/costume, e sim por estarem de alguma forma comprometidos com eles (ou porquê não são proprietários das embarcações/canoas, ou por dívidas).

Portanto, o desempenho desse indicador foi considerado baixo para as cadeias da corvina e da manjuba, e médio para o camarão sete-barbas. 


\subsection{Análise comparativa de desempenho das cadeias}

De uma forma comparativa, os critérios de equidade, eficiência e empoderamento, e os parâmetros indicativos e avaliações do desempenho correspondentes aos critérios a cada cadeia de valor estudada estão dispostos no Quadro 10.

Quadro 10 - Comparação dos desempenhos das três cadeias produtivas. Sistema de partilha (PAR), comissão (COM), autônomo (AUT); carteira assinada (CAS); Não se aplica (NA).

\begin{tabular}{|c|c|c|c|c|c|c|}
\hline \multirow[b]{2}{*}{ Critérios } & \multirow[b]{2}{*}{$\mathrm{N}^{\mathrm{o}}$} & \multirow{2}{*}{$\begin{array}{l}\text { Parâmetros } \\
\text { indicativos }\end{array}$} & \multicolumn{3}{|c|}{ Cadeia produtiva } & \multirow{2}{*}{$\begin{array}{c}\text { Desempenho } \\
\text { total }\end{array}$} \\
\hline & & & Corvina & $\begin{array}{c}\text { Camarão } \\
\text { sete-barbas }\end{array}$ & Manjuba & \\
\hline \multirow{3}{*}{ } & 1 & $\begin{array}{l}\text { Distribuição dos } \\
\text { benefícios }\end{array}$ & Baixo & Baixo & Médio & \multirow{3}{*}{ صִ } \\
\hline & 2 & $\begin{array}{l}\text { Programas } \\
\text { federais }\end{array}$ & Baixo & Baixo & Baixo & \\
\hline & 3 & $\begin{array}{l}\text { Participação do } \\
\text { gênero feminino }\end{array}$ & Baixo & Médio & Baixo & \\
\hline \multirow{5}{*}{ 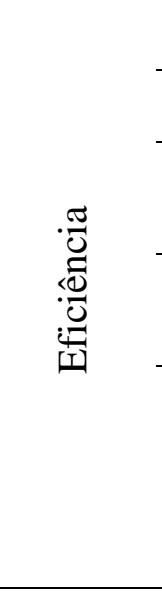 } & 4 & Valor da pescaria & $\mathrm{R} \$ 2.838 .930,20$ & $\mathrm{R} \$ 3.444 .585,05$ & $\mathrm{R} \$ 3.816 .775,82$ & \multirow{5}{*}{ 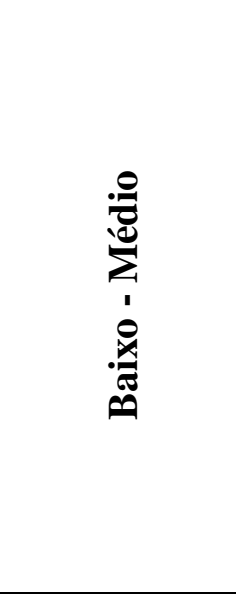 } \\
\hline & 5 & Infraestrutura & Médio & Médio & Baixo & \\
\hline & 6 & $\begin{array}{l}\text { Valor agregado } \\
\text { ao produto }\end{array}$ & Baixo & Médio & Baixo & \\
\hline & 7 & $\begin{array}{l}\text { Deficiências e } \\
\text { entraves }\end{array}$ & Baixo & Baixo & Baixo & \\
\hline & 8 & $\begin{array}{l}\text { Medidas de } \\
\text { regulamentação e } \\
\text { ordenamento da } \\
\text { pesca }\end{array}$ & Médio & Médio & Médio & \\
\hline \multirow{4}{*}{ 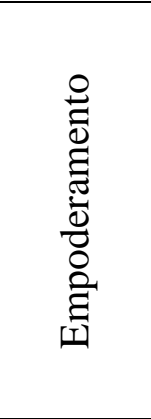 } & 9 & $\begin{array}{l}\text { Organizações } \\
\text { representativas }\end{array}$ & Baixo & Baixo & Baixo & \multirow{4}{*}{ 胥 } \\
\hline & 10 & $\begin{array}{l}\text { Relação de } \\
\text { trabalho }\end{array}$ & $\begin{array}{c}\text { PAR, COM } \\
\text { e CAS }\end{array}$ & $\begin{array}{c}\text { PAR, AUT } \\
\text { CAS } \\
\end{array}$ & $\begin{array}{l}\text { PAR, AUT, } \\
\text { COM e CAS }\end{array}$ & \\
\hline & 11 & Atravessadores & Médio & Nulo & Alto & \\
\hline & 12 & $\begin{array}{l}\text { Decisão para } \\
\text { comercialização }\end{array}$ & Baixo & Médio & Baixo & \\
\hline \multicolumn{3}{|c|}{ Desempenho total } & Baixo & Médio & Baixo & \\
\hline
\end{tabular}


Os parâmetros indicativos, aqui desenvolvidos, baseados nos critérios de equidade, de eficiência, e de empoderamento, mostraram-se eficazes para discutir o desempenho das cadeias de valores da pesca artesanal.

Separadamente, o critério de equidade apresentou baixo desempenho, o critério de eficiência apresentou baixo-médio, enquanto que o critério de empoderamento apresentou médio desempenho. Os parâmetros indicativos que apresentaram pior desempenho, nas três cadeias produtivas estudadas, foram: citação de deficiências e entraves, adesão a programas públicos federais e participação em organizações representativas.

Já os parâmetros que apresentaram melhor desempenho, quando comparados entre as cadeias produtivas estudadas, foram: decisão para comercialização do produto na cadeia do camarão sete-barbas (a maioria dos produtores podem escolher o comprador, inclusive pelo melhor preço oferecido), e a baixa presença e dependência de atravessadores na cadeia da manjuba para a comercialização do pescado.

Comparativamente, para os três critérios, as cadeias da corvina e da manjuba apresentaram baixo desempenho, enquanto que a cadeia do camarão sete-barbas apresentou um desempenho médio. Pode-se aferir que a cadeia da corvina apresentou o pior desempenho comparado as demais cadeias, pois em relação ao critério de equidade há baixa aderência aos programas federais, e baixa participação do gênero feminino, em relação ao critério de eficiência há menor valor de pescaria, baixo valor agregado ao recurso, e alta presença de deficiências e entraves ao longo da cadeia, e em relação ao critério de empoderamento há fraca organização representativa dos atores envolvidos e baixo poder de decisão de comercialização entre o pescador e o próximo elo. Nessa cadeia, não foi diagnosticado o alto desempenho em nenhum indicador analisado. 


\section{DISCUSSÃO}

As cadeias produtivas e de valores tem apresentado um destaque cada vez maior nos estudos econômicos dos recursos pesqueiros, uma vez que o conhecimento interativo dos diversos segmentos de sua estrutura (meios de produção, produtos e insumos, custos e lucros, benefícios econômicos, mercados e elos produtivos) permite avaliar o desempenho e as possibilidades de se introduzirem modificações e melhorias necessárias (IVO et al., 2013).

O presente estudo buscou contribuir para a promoção de melhorias nos processos de produção, distribuição e comercialização dos recursos pesqueiros da pesca artesanal marinha.

\subsection{Estrutura e funcão das cadeias produtivas e das cadeias de valor}

A estrutura das cadeias de produção pode variar em complexidade, dependendo da diversidade de atores e das atividades específicas que desempenham, tanto no sentido de adicionar valor ao produto através do processamento, ou somente da extensão da comercialização (SHAMSUDDOHA, 2007; BOLWIG et al., 2010). Nos países em desenvolvimento, as cadeias produtivas são, em geral, fragmentadas e vagamente desorganizadas, a relação entre os atores da cadeia tende a ser mais emocional e cativo, fornecendo de um lado, mais flexibilidade na comercialização, bem como baixa transação de custos, mas por outro lado, torna-se um sistema fraco no qual as pessoas não estão acostumadas a uma relação de contrato legal (BRIONES e GARCIA, 2008).

As cadeias produtivas da corvina e do camarão sete-barbas podem ser caracterizadas pela sua forte estrutura linear, decorrente da presença dos intermediários, sejam atacadistas ou plantas de processamento, nos quais estes ocupam uma posição central na comercialização do pescado. Na cadeia da corvina, o atacadista CEASA (RJ) detém $89 \%$ da produção desembarcada em Ubatuba (SP), enquanto que na cadeia do camarão sete-barbas, as plantas de processamento detêm $96 \%$ da captura desembarcada no Rio do Meio, Guarujá (SP).

Diversos estudos encontraram esse padrão de linearidade nas cadeias produtivas da pesca artesanal. Entre estes, destacam-se o de AHMED (2007) em 
Bangladesh, que encontrou $60 \%$ da produção da hilsa (Tenualos ilisha) correspondendo ao principal fluxo de comercialização (pescador, atravessador, fornecedores e atacadista), e o de LOC et al. (2010), no Vietnã, que encontrou 91\% correspondendo ao principal fluxo do panga (Pangasius hypophthalmus) sendo através do produtor, planta de processamento e mercado de exportação. Alguns trabalhos responsabilizam a alta centralização da produção pelos atacadistas, pois estes são atores de grande escala, responsáveis pela entrada do pescado nos centros varejistas (BROWN et al., 2010), ou mesmo que o processo de beneficiamento pode representar uma barreira para que outros atores ingressem na comercialização, uma vez que isso requer o conhecimento das atividades de processamento e qualidade do produto (WAMUKOTA et al., 2014)

Alguns fatores podem ser apontados para a forte estrutura linear encontrada nas cadeias da corvina e do camarão sete-barbas. No caso da corvina, há três principais fatores que contribuem para que o fluxo de distribuição ocorra quase que exclusivamente via atacado CEASA no Rio de Janeiro: 1) o consumo de pescado no Rio de Janeiro é superior a São Paulo (BARROSO e WIEFELES, 2010; NEIVA, 2010); 2) o valor de venda no atacado, que é maior que no CEASA de SP; 3) e a maior aceitabilidade desse pescado pelo consumidor do Estado do Rio de Janeiro (BARROSO e WIEFELES, 2010). No caso do camarão sete-barbas, podem-se aferir dois motivos: 1) a infraestrutura de desembarque do pescado, os píeres são privados e pertencem às plantas de processamento locais; 2) a alta demanda dessa matéria prima para as plantas de processamento. Já no caso da manjuba, a estrutura da cadeia é ramificada em dois principais fluxos (via atacadista e plantas de processamento). Uma vez que a cadeia apresenta um caráter difuso, ou seja, mais ramificada com diversos segmentos e fluxos de produção, essa pode funcionar como um gerador de renda para um grupo maior de atores envolvidos, sendo isso uma implicação positiva no modo de vida de todos os atores envolvidos na cadeia produtiva (WAMUKOTA et al., 2014).

Em relação a complexidade ou simplicidade das cadeias produtivas estudadas, a cadeia da corvina apresenta uma estrutura mediana uma vez que possui somente cinco segmentos, um importante fluxo de distribuição, e comercialização principalmente do pescado inteiro/fresco, e proveniência dos consumidores é de nível estadual (São Paulo, Rio de Janeiro e Minas Gerais). No caso do camarão, a estrutura é simples, (apresentando também um importante canal de comercialização), e há também cinco segmentos, atendendo, principalmente, o consumidor da Região Metropolitana da 
Baixada Santista, devido principalmente a ser tratar de uma região turística. Já a estrutura da cadeia da manjuba, apresenta maior complexidade devido ao número de segmentos e atores identificados. A distribuição do pescado beneficiado possui abrangência nacional, há dois principais fluxos de distribuição, e por fim, o beneficiamento possui três diferentes tipos, aumentando a possibilidade de fornecimento e agregação de valor ao produto.

O interessante em relação à complexidade da cadeia produtiva da manjuba é que, entre os três sistemas pesqueiros estudados, essa pode ser considerada a pescaria mais artesanal e rudimentar, visto que a pesca ocorre na praia, não há qualquer tipo de infraestrutura tanto para desembarque como para o acondicionamento do pescado, baixo poder de armazenamento das canoas a remo (no máximo uma tonelada), alta dependência da época da safra do recurso, além da região de Iguape apresentar baixo desenvolvimento econômico e social, comparado as regiões de Ubatuba (SP) (litoral norte) e Guarujá (SP) (litoral centro). A quantidade de embarcações é alta, a pescaria é realizada na praia, às margens do Rio Valo Grande, na qual a área de pesca é aproximadamente $0,6 \mathrm{~km}^{2}$, ou seja, há uma quantidade elevada de canoas em uma região muito pequena.

A maioria da corvina desembarcada em Ubatuba (SP) vai para o Estado do Rio de Janeiro, no qual é comercializada inteira e resfriada (sem beneficiamento). Enquanto que para o camarão sete-barbas desembarcado no Rio do Meio, Guarujá (SP) toda a produção desse recurso é consumida na região do Estado de São Paulo, principalmente na Região Metropolitana da Baixada Santista, e comercializada após o beneficiamento (limpeza e descabeçamento). Por fim, a produção de manjuba desembarcada na Barragem do Valo Grande, a maioria é comercializada por estabelecimentos do Estado de São Paulo (capital, interior e litoral), comercializada inteira/resfriada (pelos atacadistas), e comercializada processada (congelada, eviscerada, em filé ou salgada), caracterizando esse Estado como o grande consumidor do sistema pesqueiro da manjuba desembarcada em Iguape, e o alcance de distribuição é nacional exclusivo para o pescado processado. Assim, as três cadeias são voltadas para o mercado doméstico, diferenciando somente da abrangência da distribuição dos recursos 


\subsection{Desempenho das cadeias produtivas}

Para que haja uma real sincronia entre os segmentos de uma cadeia produtiva é necessário que os elos e os fluxos estejam em sintonia e cooperando entre si (CASTRO, 2001). Sendo assim, a avaliação e o monitoramento da cadeia produtiva devem ser constantes e efetivos, pois, através do acompanhamento dos parâmetros indicativos de desempenho os problemas ou oportunidades de melhoria na cadeia como um todo ou mesmo nos segmentos que possuem alguma fragilidade poderão ser identificados, assim possibilitando a implantação de ações de melhoria proporcionando a competitividade saudável ao longo da cadeia de valor (DURSKI, 2003).

\subsubsection{Distribuição dos benefícios}

A distribuição dos benefícios ao longo das cadeias de valores é influenciada principalmente pela quantidade de intermediários e dos atores envolvidos. Essa quantidade depende da extensão do mercado, da qualidade e do processamento do pescado, da distribuição, da natureza dos produtores e dos consumidores, e também das considerações do mercado consumidor que diferem de região para região, tais como hábitos alimentares e padrão de consumo das pessoas (SHAMSUDDOHA, 2007; De SILVA, 2011; ALAM et al., 2012).

Os resultados deste trabalho apontaram que a distribuição dos benefícios acumulados nas três cadeias de valores nos principais fluxos de distribuição, a maior a margem de comercialização bruta $(\mathrm{MCB})$ na cadeia da corvina inteira/resfriada é do pescador (47,3\%), enquanto que na cadeia do camarão sete-barbas limpo é da planta de processamento $(84,2 \%)$, e na cadeia da manjuba inteira/resfriada é do pescador $(37,3 \%)$. ALAN et al. (2012) encontraram que nas cadeias de valor dos camarões (Macrobrachium rosenbergii, Penaeus monodon e Litopenaeus vannamei), das carpas (Labeo rohita e Catla catla), do panga (Pangasius hypophthalmus) e da tilápia (Oreochromis nilotica) comercializados inteiros, em Bangladesh, o pescador apresentou MCB maior (aproximadamente 70\%).

A MCB deve cobrir os custos envolvidos na transferência (ou beneficiamento) de um segmento para os próximos segmentos e proporcionar um retorno razoável 
(CRAWFORD, 1997). Ou seja, os dados encontrados da MCB podem ser explicados, principalmente, pelos custos envolvidos em cada segmento. Custos esses que não foram levantados nesse estudo, mas conforme literatura e estudos publicados anteriormente, esses interferem no lucro dos atores, e consequentemente no valor de comercialização do pescado (com exceção dos segmentos do atravessador e do atacado que são atores comissionados). Os custos que podem interferir no segmento de produção são: combustível, gelo, óleo lubrificante, apetrechos de pesca (compra e manutenção), manutenção da embarcação, seguros sociais e taxas (embarcação e tripulantes), e pagamento à tripulação (GUDMUNDSSON et al., 2006; SOUZA et al., 2009; e ALAN et al., 2012). Por exemplo, o custo total de uma embarcação de arrasto de camarão setebarbas é de $91 \%$, enquanto que para uma embarcação de emalhe de fundo de corvina, o custo total é de $75 \%$ do lucro bruto total por viagem de pesca (GASALLA et al., 2010).

Os custos de viagem da pescaria da corvina poderiam justificar a maior MCB, porém não justificam, uma vez que o valor da primeira venda, ou seja, o valor do pescado entre o produtor e o atacado (com o atravessador de intermédio da transação) só é definido pelo atacadista, uma vez que o pescado chega no centro atacadista (no caso, no CEASA-RJ) e o valor é estipulado no dia da venda. Em suma, o pescador não sabe qual o valor do pescado quando retorna da pescaria. Além dos custos de viagem, o pescador também é responsável pelos custos do pescado vendido no atacado, tais como: despesas com o frete (gelo e transporte), taxas de descarga do caminhão e estacionamento, diária do motorista, comissões do atravessador (se houver) e do atacadista, além das taxas de nota fiscal de transporte interestadual.

No caso da cadeia de valor do camarão sete-barbas, os custo totais de uma embarcação podem intervir no valor de comercialização do pescado. Isso porque, o pescador comercializa direto para as plantas de processamento, e o valor é ajustado semanalmente por elas, e fundamentado a partir do preços do combustível e da demanda do produto. E, apesar de mais rentável para o pescador comercializar direto para os varejistas locais, isso não é uma prática usual, por dois motivos: o papel das plantas de processamento como auxiliadores financeiros (empréstimos e adiantamento do pagamento), e o fato das plantas de processamento serem donas da maioria das embarcações. 
Os custos que podem interferir no segmento de beneficiamento são: matéria prima, pagamento de funcionários, empacotamento, transporte, e demais despesas (GUDMUNDSSON et al., 2006). Além desses custos, na cadeia do camarão sete-barbas há dois outros pontos sobre o beneficiamento: 1) equipamentos utilizados no processo de descabeçamento e descascamento do camarão (esteiras), e o uso das descabeçadeiras para seleção do camarão; 2) as proporções do peso do camarão inteiros para o processamento do camarão limpo (normalmente é 2,2:1; mas podendo chegar a 3:1).

Enquanto que na cadeia de valor da manjuba, os valores dos custos não se aplicam, uma vez que a maioria dos pescadores artesanais não possuem custos para realizar essa atividade. Com exceção de somente três produtores que são donos das embarcações e equipamentos de pesca, esses vendem o pescado para outros donos de material com a diferença de $\mathrm{R} \$ 0,50 / \mathrm{Kg}$ do valor que os demais pescadores recebem. $\mathrm{O}$ dono do material, que possui custos de manutenção da embarcação e redes, imposto da emissão da nota fiscal de produto, e pagamento à tripulação, gelo, manutenção dos equipamentos de armazenagem tais como freezer e câmaras frias, e pagamento aos empregados ou ajudantes.

Quando se compara as margens de comercialização total (MCT) das seis cadeias de valores dos produtos que foram estudados (corvina inteira/resfriada, manjuba inteira/resfriada, manjuba salgada, manjuba eviscerada, camarão sete-barbas limpo e camarão sete-barbas descabeçado) é claramente perceptível que os recursos processados possuem maior valor, tais como a manjuba eviscerada (7,6 vezes) e o camarão setebarbas limpo (4,0 vezes). Em contrapartida, os menores valores de MCT são dos recursos vendidos inteiros/resfriados, tais como a corvina (2,1 vezes) e a manjuba (2,6 vezes). ARCHIACONO (2007) encontrou para a cadeia do polvo inteiro (Octopus vulgaris), em São Paulo,o MTC de 4,0 vezes, enquanto que LOC et al. (2010), no Vietnã, encontraram para o valor do panga (Pangasius hypophthalmus) 1,25 vezes, e para a carpa (Henicorhynchus spp. e Labiobarbus spp.) 2,9 vezes, enquanto que WAMUKOTA et al. (2014) encontraram para o pepino do mar (Holothuria scabra, H. nobilis, $H$. spinifera, e $H$. fuscogilva), no Kenya, 2 vezes. Alguns estudos apresentaram evidências de que a maioria dos benefícios gerados ao longo da cadeia de valor é detida pelo setor da transformação da indústria de pescados, e que essa tendência é demonstrada nas pescas tanto dos países em desenvolvimento como dos países desenvolvidos (RUSSEL e HANOOMANJEE, 2012) 
Os fatores que podem afetar os preços dos recursos pesqueiros são discutidos em diversos trabalhos. Por exemplo, características dos mercados de consumo e da escassez de oferta (WAMUKOTA et al., 2014), ou mesmo consumo do pescado impulsionado por crenças e tradições culturais, particularmente em torno de elementos da medicina tradicional (BROWN et al., 2010). O preço do hilsa (Tenualosa ilisha), em Bangladesh, depende da qualidade, tamanho e peso, época do ano, da estrutura do mercado, e da oferta e demanda, e no qual é determinado pela negociação direta entre os vendedores e compradores (ALAN et al., 2012).

O valor da primeira comercialização da corvina é estabelecido pelo intermediário atacadista, através dos pregões diários realizados por eles, conforme os seguintes critérios: oferta e demanda e, posteriormente, a qualidade do pescado. Já o valor da primeira comercialização do camarão sete-barbas é estabelecido semanalmente pelas plantas de processamento, levando em consideração o preço do óleo diesel, o período da safra e a procura pelo recurso.

Quando há um canal de comercialização para a exportação do pescado na cadeia produtiva, o atacadista não é usualmente significante em países em desenvolvimento, mas a maioria dos processadores está envolvida com o comércio internacional, e nesse caso os processadores e exportadores geralmente são as empresas líderes da cadeia, e estas determinam o preço global (valor) que flui para os segmentos anteriores (BRIONES e GARCIA, 2008).

\subsubsection{Programas federais e infraestrutura das cadeias produtivas}

A adesão aos programas federais implantados foi considerada baixa para os três cadeias produtivas. Nota-se que os programas existentes, o Seguro-defeso, o Plano Safra da Pesca e Aquicultura (incentivo ao crédito) e o Programa de subvenção econômica ao preço do óleo diesel são programas de ações imediatas, ou seja, sua implantação não altera positivamente ao longo prazo esses sistemas pesqueiros, nem os segmentos da cadeia envolvidos nesses programas.

O seguro defeso está implantado nos sistemas pesqueiros do camarão setebarbas e da manjuba, sendo esse benefício fornecido aos pescadores artesanais por três meses (mar-maio) e quatro meses (nov-fev), respectivamente. Devido à ineficiência da 
condução dessa política tais como, a falta ou baixa fiscalização, a gestão dos recursos de forma desconectadas com os diferentes setores, e principalmente a desconexão do início do defeso com o início do recebimento do seguro (atrasos esses que podem chegar a dois meses) podem prejudicar ainda mais a manutenção do recurso pesqueiro (MENDONÇA e LUCENA 2013).

O Plano Safra da Pesca e Aquicultura e o Programa de subvenção econômica ao preço do óleo diesel são programas implantados no sistema pesqueiro da corvina e do camarão sete-barbas, respectivamente. Mesmo esses programas sendo de incentivos financeiros (crédito, e subsídio) a maioria dos produtores, sejam pescadores ou donos de apetrecho, não usufruem desses programas. As razões para tais falhas variam de controles e administração inadequadas e dificuldades em estabelecer prioridades justas e viáveis de crédito para garantir o pagamento de dívidas, portanto, os pescadores artesanais viram-se obrigados a optarem por vias informais para obtenção de créditos através de empréstimos sem juros via atravessadores (MERLIJN, 1989). A burocracia existente, o pequeno número de postos de combustíveis cadastrados até dificuldades do pescador para o preenchimento das guias também são apontados como entraves impossibilitando a busca por esses programas (AZEVEDO et al., 2014).

Talvez o programa mais interessante, devido a sua proposta de fortalecimento da cadeia produtiva do pescado é o Programa de Apoio a Cadeia Produtiva do Pescado. Porém, além de ser um programa com ações de disponibilizar equipamentos de Fábricas de Gelo e câmaras frigoríficas somente para o segmento de produção, esse até o momento não foi implantado em nenhum dos três sistemas pesqueiros estudados. Além disso, a demanda por infraestrutura na cadeia produtiva do pescado vai além da necessidade de fábricas de gelo e câmaras frigoríficas. Esse trabalho apontou que ao longo das cadeias de produção, o desempenho em relação às infraestruturas dos segmentos foi considerado médio, ou seja, no geral, as cadeias produtivas não possuem a metade das infraestruturas necessárias para armazenamento, distribuição e comercialização do pescado, inclusive, nos segmentos de produção das três cadeias, não há câmeras frias ou freezers para armazenamento adequado da captura, e no caso do sistema pesqueiro da manjuba, não há nem a infraestrutura de um píer para o desembarque da produção. 
Os programas federais atuais são ineficientes e ineficazes para a melhoria dos atores da cadeia de produção da pesca artesanal, sobretudo para o segmento produtivo, no caso os pescadores artesanais, como por exemplo, o seguro defeso ou o incentivo ao crédito; e para o segmento de processamento, no caso de plantas de processamento de pequena e média escala, como por exemplo, o Programa de Apoio a Cadeia Produtiva do Pescado, uma vez que a demanda por infraestrutura da cadeia produtiva vai além da necessidade de caminhões frigoríficos e fábricas de gelo.

A falta de locais adequados para o desembarque do pescado, e a não existência de locais para armazenamento, ou processamento, para esse segmento produtivo (pescadores e donos de apetrecho) são os principais problemas diagnosticados. Locais adequados para o processamento do recurso, a fim de agregar valor ao produto, também é um grande problema existente, como, por exemplo, na cadeia do camarão sete-barbas, uma vez que algumas plantas de processamento não possuem alvará sanitário ou certificado de inspeção sanitária para realizar tal atividade. Apoios governamentais, ou mesmo de ONG, poderiam fornecer vias menos burocráticas e mais acessíveis à realidade do produtor artesanal, tais como obtenção de créditos financeiros, tanto para modernizar os apetrechos de pesca, bem como impulsionar processos de beneficiamento do pescado e possibilita agregar valor ao recurso.

\subsubsection{Deficiências e entraves nas cadeias produtivas e medidas de regulamentação e ordenamento da pesca}

Os principais entraves que limitam as atividades nas cadeias produtivas estudadas são voltados para o setor de produção. A falta de infraestrutura de desembarque, armazenamento, transporte e venda adequada foi apontado pelos atores das cadeias da corvina e da manjuba, enquanto que a fraca organização da cadeia produtiva, foi apontado pelos atores nas cadeias do camarão sete-barbas e da manjuba. Nota-se que os próprios atores enxergam a fragilidade de organização da cadeia dentro dos segmentos, no qual muitos deles dizem que entre os atores do segmento não há união, e muitas vezes deslealdade ao invés de cooperação. Na cadeia produtiva da lagosta (Panulirus argus e P. laevicauda), no Brasil, revelou-se que há necessidade de investimentos para seu desenvolvimento tais como, renovação da frota, compra de 
apetrechos de pesca, modernização das plantas de processamento e de transporte e criação e modernização de entrepostos e estruturas de recepção (IVO et al., 2013).

A redução da disponibilidade de peixes para a atividade de pesca também foi apontada como um dos grandes entraves da cadeia produtiva, uma vez que esses pescados são a matéria prima de toda a cadeia. Alguns estudos apontam que os estoques pesqueiros da corvina, do camarão sete-barbas e da manjuba, no Sudeste do Brasil, encontram-se sobre-explorados, afetando negativamente as próximas safras do recurso (VASCONCELLOS et al., 2007b, e a Lista Oficial das Espécies de Invertebrados Aquáticos e Peixes Ameaçados de Extinção e Sobreexplotados ou Ameaçados de Sobreextplotação - IN 05 21/05/04 e alterações).

A pesca ilegal foi apontada na cadeia da corvina, sendo o principal entrave, uma vez que os atores relataram diversos casos de pesca da corvina por traineiras, que é proibida, alegando falta de fiscalização por parte da polícia ambiental sobre as embarcações de cerco, que em muita vezes, em apenas um lance representa a captura da produção do mês de uma embarcação de emalhe, desvalorizando o pescado no mercado (aumentando a oferta e diminuindo o valor de comercialização). Já na cadeia do camarão, o principal entrave está relacionado com o período de defeso, que depois de muitas controversias, entre pesquisadores, atualmente não há um consenso sobre qual a época ideal no período de recrutamento ou no de reprodução (IP, 2010; SOUZA et al., 2011). E na cadeia da manjuba, os atores apontaram a dificuldade em obter documentos necessários para a atividade da pesca, devido a burocracia excessiva e o atraso em renovar a carteirinha de pesca.

Todas essas medidas de manejo estão dispostas em requisitos legais e passíveis de multa quando não cumpridas. E todas são medidas de manejo pontuais ao recurso alvo da pesca, com uma visão totalmente limitada e não integrada ao ecossistema como um todo. A gestão da pesca foca suas estratégias baseada somente na pesca propriamente dita, como um processo meramente tecnológico, independente das variáveis culturais ou sociais com foco em restrições baseadas em parâmetros naturais, somente para manter os estoques pesqueiros nos Máximos Rendimentos Sustentáveis (BERKES e KALIKOSKI, 2006). 


\subsubsection{Valor médio das pescarias e do valor agregado ao produto}

Quando o recurso pesqueiro é beneficiado, o valor de comercialização desse produto é aumentado, visto que é inserido uma mão de obra diferenciada e insumos necessários para o processamento do recurso, tais como, energia, água, maquinário, processo de congelamento e rotulagem, e uma vez beneficiados por processadores, os produtores recolhem um valor insignificante, além de informações inadequadas sobre as oportunidades de mercado e o real valor os preços de venda e custos, tendências e necessidades do consumidor (MWIRIGI et al., 2012; BJORNDAL et al., 2014).

Há três situações de comercialização dos recursos pesqueiros beneficiados até o varejo das cadeias produtivas estudadas: a corvina que é beneficiada somente $4,7 \%$ da produção total, através de uma planta de processamento; o camarão sete-barbas que é comercializado $100 \%$ após o beneficiamento, seja limpo ou descabeçado, pelas plantas de processamento; e a manjuba que $38 \%$ da produção é beneficiada seja em filé, eviscerada, ou salgada. Um estudo comparou quatro cadeias de valores de recursos pesqueiros, analisadas a partir do valor líquido acrescentado a cada segmento, destacou que o lucro do produtor torna-se relativamente mais baixo, à medida que o produto se torna mais processado (GUDMUNDSSON et al., 2006).

Portanto, a agregação de valor ao produto, pelo segmento de produção, seja pelos pescadores, como os donos de apetrechos poderiam representar uma melhora de renda e de valor de comercialização do produto para o varejo, ou mesmo direto para o consumidor final. Um exemplo disso é o processamento da manjuba por alguns pescadores que produzem o bolinho de manjuba (chamados de casadinhos, croquetes, espetinho de manjuba), ou mesmo fazem porção de moquecas congeladas e vendem para os comércios locais. Esse processamento aumenta o valor de comercialização, no qual o kilo pode chegar a seis vezes o valor do pescado vendido inteiro para os donos de redes. Já no caso do camarão sete-barbas, no qual a produção é beneficiada pelas plantas de processamento, contribui para a baixa rentabilidade dos pescadores.

Um melhor desempenho econômico para essa atividade extrativista poderia ser implementado por medidas como a criação de cooperativa comunitária para beneficiamento do pescado produzido, possibilitando que os pescadores se apropriem de uma maior parcela da renda gerada pela atividade (SOUZA et al., 2011). Outra opção seria a interferência e apoio do governo, seja local ou regional, em incentivar a criação 
de locais com infraestrutura para as comunidades de pesca, fornecendo-lhes as diretrizes operacionais claras e benéficas e nas áreas de agregação de valor e comercialização, como por exemplo, taxa zero de alguns maquinários (BJORNDAL et al., 2014).

Quando se beneficia um recurso pesqueiro, seja filetado, salgado ou eviscerado, há agregação de valor a esse produto novo, e assim, o valor de venda dele é superior ao produto que não foi processado. Isso é evidente na cadeia de valor da pesca artesanal também, pois à medida que o produto se torna mais processado, a margem de comercialização líquida do segmento do produtor. Ou seja, se o produtor que vende o pescado in natura, devido a diversos motivos, conseguisse processar o pescado, com certeza o rendimento desse pescador seria melhor, ou seja, maior o lucro, pela mesma quantidade de pescado. E isso poderia ocorrer, seja como processador individual, como por meio de uma cooperativa, onde diversos produtores estariam reunidos para melhorar o rendimento de uma forma associativa. Outra forma seria promover a busca de novos produtos através da viabilização de ações pontuais de processamento do recurso.

\subsubsection{Participação da mulher na cadeia produtiva}

As mulheres ainda apresentam um papel pequeno nas três cadeias produtivas estudadas. Em relação ao segmento de produção, não há nenhuma participação da mulher como pescadora artesanal ou dona de apetrechos, e também não há representatividade entre os atravessadores e os atacadistas encontrados. A presença em estabelecimentos varejistas é notada, mas discreta. O único segmento que a mulher exerce a atividade é no segmento da transformação do recurso, nas plantas de processamento. Quase todos os envolvidos no processo de beneficiamento do camarão sete-barbas, seja descabeçar ou limpar, são mulheres. E no processo de salga, filetagem e evisceração da manjuba, também há presenças significantes de mulheres como a principal mão de obra. Os resultados desse trabalho corroboraram com os demais estudos.

As mulheres desempenham papéis importantes na atividade pesqueira, inclusive nas atividades pós-captura, e representam mais que a metade da força de trabalho em pescarias artesanais nos setores primários e secundários, que em grande parte é a consequência de normas sociais e culturais, que reduziram em geral o acesso 
das mulheres aos recursos e seu poder de decisão (FAO, 2010). Papéis esses diversificados que geralmente trabalham no beneficiamento do pescado, produzindo subprodutos como filetagem e farinha de pescado, o peixe salgado, a carne de siri e descascando o camarão (GALVÃO, 2013; BJORNDAL et al., 2014), mas permanecem marginalizadas inclusive para tomadores de decisão, e geralmente são pouco remuneradas (BENNETT 2005; Di CIOMMO, 2007). O papel das mulheres nas fábricas de processamento também são associados à insegurança no trabalho, problemas de saúde e assédio (De SILVA e YAMAO, 2006).

Ao longo da história das cadeias de valores da pesca, as mulheres têm desempenhado um papel significativo, mas muitas vezes invisível enfrentam grandes dificuldades incluindo a falta de reconhecimento da sua contribuição, isolamento social, as barreiras culturais, falta de aceitação, sendo negligenciada ou ignorada pelos gestores da indústria pesqueira e os tomadores de decisões políticas, gerando a desigualdade, as más condições de trabalho e o acesso limitado a recursos (BJORNDAL et al., 2014).

Embora a lei 11.959/09 reconheça os direitos das pescadoras e considera suas atividades como trabalho, muitas ainda têm dificuldades para formalizar o ofício de pescadora, como exemplo, tem-se atividades de pré e pós-captura que muitas vezes ficam excluídas da definição formal de pesca (MANESCHY, 1997).

Em pescarias de pequena escala, as mulheres desempenham papéis importantes na atividade pesqueira, inclusive na pós-captura. Porém, esses papéis quando não marginalizados, são praticamente invisíveis, como por exemplo, as mulheres responsáveis por $100 \%$ na produção do camarão sete-barbas descabeçado. Marginalizadas, pois trabalham em condições precárias de saúde e segurança ocupacional, e muitas vezes fazem jornadas de trabalho exaustivas para atender a produção, recebendo pouco para essa atividade. E invisíveis, pois aos olhos da sociedade, seus trabalhos são imperceptíveis e aos olhos do governo, esse segmento não possui quaisquer benefícios, ou há programas, planos ou ações voltadas à melhoria das condições de trabalho e de vida desse gênero. 


\subsubsection{Relações de trabalho e organizações representativas na cadeia produtiva}

Um padrão sobre a relação de trabalho entre os segmentos produtivos nas três cadeias estudadas foi encontrado: todos os pescadores possuem uma relação de trabalho através da partilha dos lucros pelo sistema de partes: no caso da corvina e do camarão sete-barbas, o dono da embarcação é o que recebe mais, seguido do mestre e os tripulantes; e no caso da manjuba, há a divisão igualitária do valor recebido devido à venda da produção entre os pescadores. Alguns estudos, descrevem que esse sistema por partes é uma máscara utilizada pelo capital para explorar melhor a força de trabalho do pescador, pois esse sistema responde melhor às necessidades do capital num estágio determinado de desenvolvimento das forças produtivas, levando a uma intensificação e a um prolongamento da jornada de trabalho, além da partilha indevida das despesas comuns, meio esse criado pelo armador em ao menos, caso a pescaria não produza tanto, uma parte do capital investido previamente retorne (MORDREL e BIDET input DIEGUES, 1987).

No sistema de comissão estabelecido pelos atravessadores e atacadistas não há uma convergência no valor exato da comissão. Por exemplo, a comissão do atravessador da cadeia da corvina varia entre $10-13 \%$, enquanto que para o atacadista $12-15 \%$. Pode parecer que a comissão do atravessador é pouca, mas quando há somente três atravessadores responsáveis praticamente por quase toda a produção de 20 embarcações, há um afilamento da produção, então o rendimento final para o atravessador é compensado. Já nas plantas de processamento, no geral, por serem estabelecimentos regularizados principalmente devido às normas de vigilância sanitária que possibilitam a comercialização de produtos beneficiados, possuem funcionários com carteira de trabalho assinada. Porém, em algumas plantas de processamento, por não possuírem licenças sanitárias, não possuem funcionários registrados, utilizam diaristas para realizar o trabalho de beneficiamento, sem contrato de trabalho, caracterizando a alta informalidade do setor nessa cadeia produtiva.

Em relação às organizações representativas, há pouca participação dessas entidades nas três cadeias produtivas estudadas: há ausência de associações e cooperativas nas três cadeias; baixo envolvimento dos pescadores no Sindicato de Pescadores; e nenhum envolvimento das plantas de processamento no Sindicato de 
Armadores e Indústria. As justificativas para o não envolvimento dos pescadores no sindicato variam desde distância, desconhecimento das ações desse órgão, até descredibilidade da atuação. LEME (1972) apud DIEGUES (1987), no seu estudo apontou que mesmo existindo um Sindicato de Pecadores, em Santos, a maioria dos pescadores não procurava esse órgão em casos de conflitos, alegando que o mesmo já estava controlado pelos armadores.

No caso dos intermediários, por exemplo, as plantas de processamento, a falta de adesão ao Sindicato de Armadores e Indústrias está principalmente no fato da ilegalidade da maioria dos estabelecimento da cadeia do camarão sete-barbas, e quanto a cadeia da manjuba está mais relacionado a não necessidade de utilizar esse Sindicato. De fato, não é estranho constatar que não há associações representativas do segmento do atravessador, visto que essa atividade é informal, e entre os próprios atravessadores há certa competitividade e inimizade, como no caso dos atravessadores da cadeia produtiva da corvina.

A relação de trabalho está muito ligada às organizações representativas existentes e atuantes. Por exemplo, uma vez que não há um sindicato de pescadores artesanais atuante, ou que ao menos não transparece segurança nas ações e na defesa aos interesses dessa classe, o pescador fica preso ao sistema de partilha por cotas do lucro ou mesmo ao sistema de comercialização via atravessador. Outro exemplo é a falta de organização social das trabalhadoras que descascam o camarão sete-barbas. Atualmente, essas mulheres são marginalizadas e pouca força têm separadas. Porém, talvez uma associação que se discuta o modo de vida atual, bem como as condições que estão submetidas se consiga melhorar o modo como trabalham e se relacionam com a atividade, tal como, melhores condições higiênicas, ocupacionais, financeiras e sociais. Empoderar os produtores artesanais, sejam eles pescadores ou donos de apetrechos, através da organização associativa baseado nas comunidades pode ajudar a diminuir os entraves nas cadeias produtivas da pesca artesanal (BRIONES e GARCIA, 2008).

Dois principais pontos para a viabilidade e continuidade das organizações associativas, sejam elas cooperativas ou associações, de pescadores artesanais, de plantas de processamento ou mesmo de estabelecimentos varejistas, é o fortalecimento da cultura cooperativista, essa baseada em conceitos e valores humanísticos, tais como solidariedade, confiança e organização funcional de grupos, com o objetivo substituir o 
individualismo pela ação coletiva (MALDONADO e SANTOS, 2006), e a formação e conscientização do indivíduo no âmbito da cidadania, por meio da educação cooperativista. Ao prestar serviços a preço de custo para seus associados, as cooperativas procuram diminuir os custos operacionais, eliminando os intermediários que se colocam em todas as fases da produção pesqueira, desde a obtenção da matériaprima à sua transformação industrial e colocação junto ao consumidor (PINHO, 1984).

Há pouca participação dos segmentos, sejam eles pescadores, armadores ou mesmo processadores nas organizações representativas, tais como colônias de pesca e sindicatos de pescadores e sindicatos de armadores e indústria, quando existentes. $\mathrm{O}$ principal motivo é a falta de confiança e segurança nas ações desses órgãos para ajudar e defender os interesses de classe, uma vez que a cultura cooperativista não está enraizada nas comunidades, ou mesmo entre os atores do mesmo segmento, a probabilidade de se implantar e fazer funcionar organizações cooperadas, tais como cooperativas ou associação, é baixa.

\subsubsection{Atravessadores e decisão para comercialização ao longo da cadeia produtiva}

Um dos grandes vieses na cadeia produtiva da pesca artesanal é a comercialização dos recursos através de um sistema de intermediação (os chamados "atravessadores") que vai do personagem individual (em geral, alguém da comunidade que se especializou na compra e venda de pescado), até os representantes de empresas de compra e financiamento da produção, gerando assim, um conjunto de regras informais e específicas, permeadas por valores de dependência, reciprocidade e leis de respeito (MALDONADO e SANTOS, 2006).

Poucas literaturas estudam ou descrevem o papel dos atravessadores na comercialização da pesca de pequena escala, e pouco se discute a importância e consequências desse segmento entre os pescadores artesanais e a inserção no mercado. Os atravessadores apresentam diversos papéis na comercialização, nos quais inclui: fornecer materiais de pesca; manter contato com os compradores, negociar preços, entregar os recursos, aquisição e armazenamento de produtos, fornecer documentos para 
viabilizar a venda e muitas vezes providenciar o transporte até o comprador (MELIJN, 1980; DIEGUES, 1983; VINH, 2008; AGBEDI e FAGBOTE, 2012).

Nas cadeias produtivas da corvina e da manjuba, um dos papéis do atravessador é auxiliar na distribuição do pescado, através da contratação do frete ou fornecimento de veículo próprio, e uma vez que, os produtores de ambas as cadeias não possuem essa infraestrutura, a presença e serviços desses atravessadores tornam-se essenciais. $\mathrm{Na}$ cadeia da corvina, por exemplo, os produtores por possuírem infraestrutura de armazenamento, acabam repassando para o atravessador assim que retornam das viagens, e muitas vezes ficam com a captura na embarcação atracada por dias, até o atravessador possuir condições em receber o pescado. Nossos resultados corroboram com alguns estudos publicados que apontam que o cenário do atravessador pode ser favorecido devido aos problemas de infraestruturas principalmente para a conservação e transporte do recurso pesqueiro, tais como a falta de áreas de desembarque adequadas, falta de fábricas de gelo e câmaras frigoríficas, além de fatores como distância física entre produtores e consumidores, e em casos onde há uma alta produção pesqueira, há necessidade de muitos atravessadores para intermediar a venda (TORRES et al., 1987; SURTIDA, 2000).

A oferta de crédito é a segunda função que define o atravessador, sendo que muitas vezes esta ocorre para assegurar as transações e criar uma subordinação do trabalho para a pesca de pequena escala, sem cobrar qualquer taxa de juros explícita, e, na maioria dos casos essas transações financeiras são tratadas numa base informal, sem burocracias comerciais, ou uma maneira de evitar os custos associados aos impostos (MELIJN, 1980; PLATTEAU e ABRAHAM, 1987; RUSSEL, 1987; CRONA, 2006; CRONA et al., 2010; e PEDROZA, 2012). Esse papel também foi encontrado na cadeia da corvina, no qual o atravessador é também o facilitador de recursos financeiros para o pescador artesanal, tanto quanto ao auxílio prévio para o abastecimento dos suprimentos para a viagem de pesca (chamado rancho) ou para o empréstimo financeiro prévio à viagem de pesca ou à venda da captura para o pescador (chamado vale). Uma vez que os pescadores recebem esse crédito financeiro, eles são obrigados a comercializar sua produção para a quitação da dívida, e geralmente, os valores estipulados pelos atravessadores são menores do que os valores de mercado (AGBEDI e FAGBOTE, 2012), garantindo assim que os atravessadores tenham acesso prioritário ao pescado, e 
fornecimento constante dos recursos (MELIJN, 1980; PLATTEAU e ABRAHAM, 1987; RUSSEL, 1987; e CRONA et al., 2010).

Esses dois papéis representados pelos atravessadores, encontrada nas cadeias da corvina e da manjuba, limita o poder de decisão na escolha de comercialização do pescado, inclusive no valor de venda. Isso foi evidenciado claramente na cadeia da corvina, no qual $85,7 \%$ dos produtores não escolhem para quem irão comercializar, simplesmente pela melhor oferta, e sim devido ao compromisso em executar as dívidas provenientes do financiamento prévio das despesas da pescaria, além do auxílio na emissão da Nota Fiscal de Produtor que muitos produtores não possuem. No caso da cadeia da manjuba, 92\% dos pescadores não escolhem para quem comercializar, e isso está atrelado por duas situações: a embarcação pertencer a um armador, portanto o pescador passa a trabalhar para o dono do apetrecho de pesca, ficando assim dependente de passar a captura para eles, além do forte vínculo entre eles, em relação a empréstimos prévios. Um estudo realizado em 1971, nas regiões de Cananéia, Iguape e Ubatuba, em São Paulo, já havia identificado a alta dependência dos pescadores com os atravessadores, ocasionado por um motivo principal: a alta perecibilidade do pescado (DIEGUES, 1983).

Por outro lado, a relação entre atravessador e pescador pode representar não uma relação de exploração, e sim uma espécie de acordo social com benefícios mútuos. Os pescadores precisam vender seu produto altamente perecível e sem demora, ter acesso imediato a empréstimos sem garantia e sem formalidades e obter insumos quando estes acharem necessário, e os atravessadores são os únicos que entendem essas necessidades (MELIJN, 1980). É uma bola de neve, na qual uma vez que essa relação patrão/empregado permanece por um tempo bastante longo e não é rentável para os pescadores, a dependência tende a ficar mais forte, e há indícios de que os pescadores da região da Indonésia estão mais interessados e confortáveis para cooperar com os atravessadores de tal forma que eles não entendem na possibilidade de estarem sendo explorados pelos atravessadores (ISTIANA et al., 2014).

Nos dias atuais, as atividades exercidas por atravessadores são eficazes quanto ao escoamento da produção, independente dessa atividade ser considerada informal. Apesar de existir alto grau de dependência na relação pescador artesanal - atravessador, tais como empréstimos de créditos pré e pós-captura do pescado e na intermediação de 
compra e venda da produção, essa relação se baseia na confiança e reciprocidade de ambos os lados. Isso se deve, principalmente, à precariedade e marginalização da atividade pesqueira de pequena escala quanto aos níveis de investimentos (públicos ou privados) em infraestrutura, assim como a falta de políticas públicas promovendo a autogestão na comercialização dos produtos, nos segmentos de produção.

Melhorar o poder de decisão dos produtores artesanais quanto ao valor de comercialização do pescado, visto que quem define esses valores não são eles, e sim segmentos a montante, tais como o atacadista ou a planta de processamento, através de cooperativas dos produtores, organizações de vendas, ou mesmo de cooperação entre os agentes da cadeia de valor, através de um modelo independente do mercado, poderia ser um caminho para um comércio mais justo. Por exemplo, nas cadeias da corvina e do camarão sete-barbas, os preços de primeira venda são definidos pelo atacadista e pelas plantas de processamento, respectivamente, sendo que esses atores definem o preço, independente do custo ou lucro que os produtores artesanais podem ou não obter. A criação de uma única operação de venda, onde toda a captura fosse comercializada por uma via só, com preços fixados de forma cooperada para beneficiar ambas as partes e obter preços mais justos para os produtores, poderia ajudar esses atores agregar valor ao recurso pesqueiro regularmente, permitindo vender para redes de supermercados ou grandes mercados com fornecimento constante de produto.

Em países desenvolvidos as informações de preço são unidirecionais, transmitida do montante a jusante nos segmentos, sendo que o grau de transparência no preço é bastante baixo (RASMUSSEN e ICH, 2005). No caso da cadeia da corvina, os pescadores informaram não saber o valor exato que é realizado a comercialização do seu pescado capturado, bem como das despesas do atravessador e do transporte até o atacadista, alegando que os motivos para isso acontecer era a inexistência de uma via confiável e transparente sobre os valores de venda, e o atravessador repassar ao pescador um só valor referente as despesas, somando sua comissão mais as despesas do frete e outras. Portanto, muitas vezes o produtor não consegue dimensionar, prever ou calcular quais são os seus reais custos da atividade pesqueira, ou mesmo saber de fato qual será o lucro obtido pela comercialização do pescado, assim, medidas que possam auxiliá-los nessa situação são necessárias, como por exemplo, treinamentos e cursos sobre comercializar o pescado baseado nos custos e demandas. 


\section{CONSIDERAÇÕES FINAIS}

A investigação comparativa da estrutura, função, e desempenho das cadeias produtivas aqui apresentadas revelou-se inédita, assim como a metodologia proposta para tal. Propiciou o entendimento da dinâmica e dos principais processos envolvidos nas cadeias produtivas da pesca artesanal da corvina, do camarão sete-barbas e da manjuba no Estado de São Paulo. Deve se considerar que desenvolver um método de análise capaz de avaliar os benefícios, e o desempenho das cadeias de produção pesqueira marinha, não é tarefa simples, mas representa uma lacuna importante para as ciências pesqueiras da atualidade, e, principalmente, para o desenvolvimento do setor pesqueiro artesanal.

Espera-se que, a partir dos métodos e resultados deste estudo, tópicos importantes sobre as cadeias produtivas e de valores da pesca de pequena escala, sirvam como subsídio para tomadores de decisão e nas definições de políticas de gestão mais eficientes visando a sustentabilidade do setor da pesca artesanal, ou ainda, para a melhoria da qualidade do pescado e dos benefícios para os atores envolvidos na cadeia de produção pesqueira. 


\section{CONCLUSÕES}

- As cadeias produtivas da pesca estudadas apresentaram alta informalidade, principalmente, entre os atores dos elos iniciais (pescadores artesanais, donos de embarcação, e atravessadores).

- As cadeias produtivas da pesca da corvina (Ubatuba) e do camarão sete-barbas (Rio do Meio, Guarujá) são simples e lineares, enquanto que a cadeia da manjuba (Iguape) é complexa e ramificada.

- Os intermediários são atores presentes nas três cadeias produtivas estudadas. A presença do atravessador, como elo entre o pescador e o atacadista se mostrou mais significativa na cadeia da corvina ( $52 \%$ da produção), sendo este essencial e necessário para o escoamento da produção pesqueira atual. Já nas cadeias do camarão sete-barbas e da manjuba, a presença de plantas de processamento ocupa esse papel, sendo que no camarão sete-barbas praticamente toda a produção escoa por esse elo.

- A distribuição dos benefícios nas cadeias produtivas estudadas resultou desigual entre os segmentos, e difere, principalmente, se o produto é ou não processado. Quando o pescado é comercializado inteiro/resfriado (corvina e manjuba), a maior margem de comercialização bruta é a do produtor, enquanto que se o pescado é processado (camarão sete-barbas e manjuba), a maior margem reside na planta de processamento.

- Quando o produto é beneficiado, o valor final ao consumidor pode ser 7,6 vezes maior do que o preço da sua primeira venda (manjuba eviscerada). Por outro lado, o produto comercializado inteiro/resfriado pode ser somente 2,1 vezes maior do que o preço da sua primeira venda (corvina).

- De uma maneira geral, nas três cadeias produtivas estudadas, o critério de equidade apresentou baixo desempenho, o critério de eficiência apresentou baixo-médio desempenho, enquanto que o critério de empoderamento apresentou médio desempenho. Comparativamente, para os três critérios, as cadeias da corvina e da manjuba apresentaram baixo desempenho, enquanto que a cadeia do camarão setebarbas apresentou um desempenho médio. 
- Os indicadores que apresentaram pior desempenho, nas três cadeias produtivas estudadas, foram: citação de deficiências e entraves, adesão a programas públicos federais e participação em organizações representativas. Já os indicadores que apresentaram melhor desempenho foram: decisão para comercialização do produto na cadeia do camarão sete-barbas (a maioria dos produtores podem escolher o comprador, inclusive pelo melhor preço oferecido), e a baixa dependência de atravessadores na cadeia da manjuba para a comercialização do pescado.

- A partir das análises, foram apontadas recomendações para melhorar o desempenho das cadeias de valores, segundo critérios de equidade, eficiência e empoderamento. Dentre elas, destacam-se: 1) políticas de gestão voltadas para melhorar a qualidade do pescado e os processos de beneficiamento, agregar valor, e valorização do pescado oriundo da pesca artesanal, assim como para a obtenção de créditos financeiros e de melhoramento na infraestrutura de armazenamento e distribuição do produto, seguindo padrões de sustentabilidade; 2) melhorias no processo de comercialização do pescado, seja na transparência das transações comerciais entre os elos, seja nos mecanismos de decisão dos valores finais dos produtos, via atuação de cooperativas e/ou maior cooperação entre os atores das cadeias, ou de capacitação sobre comercialização (por exemplo, sobre avaliação de custos e demandas do mercado); e 3) fortalecimento das organizações representativas existentes para que estas se tornem de fato atuantes, principalmente aquelas relacionadas com a participação e valorização da mulher nos processos de póscaptura, através da visibilidade e reconhecimento legal das suas atividades, diminuindo a informalidade no setor. 


\section{REFERÊNCIAS}

ABDALLAH, P.R. 1998. Atividade Pesqueira no Brasil: Política e Evolução. Tese de doutorado em Economia do Meio Ambiente. Escola Superior de Agricultura "Luiz de Queiroz”, Piracicaba (SP), Universidade de São Paulo. 137p.

AGBEDI, F.O., FAGBOTE, T.A. 2012. The role of middlemen in fish marketing in Igbokoda fish market, Ondo-state, south western Nigeria. International Journal of Development and Sustainability, v.1 n.3, 880-888p.

AHMED, N. 2007. Value chain analysis for hilsa marketing in coastal Bangladesh. Aquaculture News. n.33. 18-20p.

ALAM, F., PALASH, S, M.IAN, I.A., DEY, M. 2012. Marketing of Major Fish Species in Bangladesh: A Value Chain Analysis. A report submitted to Food and Agriculture Organization for the project entitled A Value-chain Analysis of International Fish Trade and Food Security with an Impact Assessment of the Smallscale Sector. 56p.

ANTWI-ASARE, T.O., ABBEY, E.N. 2011. Fishery value chain analysis - Ghana. 38p.

ARCHIDIACONO, A.M. 2007. Caracterização da cadeia produtiva da pesca de polvos no Estado de São Paulo. Dissertação de mestrado. Instituto de Pesca de São Paulo. 81p.

ÁVILA-DA-SILVA, A.O., CARNEIRO, M.H., MENDONÇA, J.T., SERVO, G.J.M., BASTOS, G.C.C., da SILVA, S.O., BATISTA, P.A. 2005. Produção pesqueira marinha do Estado de São Paulo no ano de 2004. Sér. Relat. Téc., São Paulo, n.20. 1-40p.

AZEVEDO, V.,G., ÁVILA-DA-SILVA, A.O., ROSSI-WONGTSCHOWSKI, C.L.D.B. 2014. Boletim Instituto de Pesca, São Paulo, v.2, n.40, 179-194p.

BARROSO, R.M., WIEFELS, A.C. 2010. O mercado de pescado na região metropolitana do Rio de Janeiro. Série: o mercado do pescado nas grandes cidades latino-americanas. INFOPESCA. 114p.

BEGOSSI, A. 2006. The etnoecology of Caiçara metopopulations (Atlantic Forest, Brasil): ecological concepts and questions. Journal of Ethnobiology and Ethnomedicine, n.2, 40p. 
BEGOSSI, A. 2010. Small-scale fisheries in Latin America: management models and challenges. MAST 2010, v.2, n.9, 7-31p.

BENDAZOLI, A., ROSSI-WONGTSCHOWSHI, C.L.D.B. (Org.). 1990. A manjuba (Anchoviella lepidentostole) no Rio Ribeira de Iguape: biologia, comportamento e avaliação do estoque. São Paulo, IBAMA/IOSUP/IP-AS/SEMA. 125p.

BENNETT, E. 2005. Gender, fisheries and development. Marine Policy, n.29, 451$459 \mathrm{p}$.

BERKES, F. 2005. Sistemas sociais, sistemas ecológicos e direitos de apropriação de recursos naturais. In Vieira et al. 2005. Gestão integrada e participativa de recursos naturais. APED, Florianópolis, 47-72p.

BERKES, F., KALIKOSKI, D. C. (Org.). 2006. Gestão da pesca de pequena escala: diretrizes e métodos alternativos. Rio Grande: Ed. Furg. *

BJORNDAL, T. 2010. Value-chain analysis. Publicado no site <http://www.fao.org/valuechaininsmallscalefisheries/projectmethodology/en/>. Acesso em 03/04/2013.

BRASIL, 1984. PORTARIA SUDEPE Nº n-54, de 20 de dezembro de 1984. Diário Oficial da União, nº 176, Brasília, DF, 26 de dezembro de 1984.

BRASIL, 1997. LEI FEDERAL nº 9.445, de 14 de março de 1997. Diário Oficial da União, nº 176, Brasília, DF, 15 de março de 1997.

BRASIL, 2004. INSTRUÇÃO NORMATIVA MMA nº 05, de 21 de maio de 2004. Diário Oficial da União, nº 102, Brasília, DF, 28 de maio de 2004.

BRASIL, 2004. INSTRUÇÃO NORMATIVA IBAMA nº 33, de 16 de junho de 2004. Diário Oficial da União, no 192, Brasília, DF, 17 de junho de 2004.

BRASIL, 2004. INSTRUÇÃO NORMATIVA MMA n 31, de 13 de dezembro de 2004. Diário Oficial da União, nº 225, Brasília, DF, 14 de dezembro de 2004.

BRASIL, 2005. INSTRUÇÃO NORMATIVA MMA $n^{\circ}$ 53, de 22 de novembro de 2005. Diário Oficial da União, nº 231, Brasília, DF, 24 de novembro de 2005. 
BRASIL, 2006. INSTRUÇÃO NORMATIVA IBAMA nº 135, de 04 de dezembro de 2006. Diário Oficial da União, nº 232, Brasília, DF, 05 de dezembro de 2006.

BRASIL, 2007. INSTRUÇÃO NORMATIVA SEAP/PR nº 18, de 27 de julho de 2007. Diário Oficial da União, no 225, Brasília, DF, 30 de julho de 2007.

BRASIL, 2008. INSTRUÇÃO NORMATIVA IBAMA nº 189, de 23 de setembro de 2008. Diário Oficial da União, nº 185, Brasília, DF, 24 de setembro de 2008.

BRASIL, 2008. INSTRUÇÃO NORMATIVA IBAMA nº 195, de 02 de outubro de 2008. Diário Oficial da União, nº 192, Brasília, DF, 24 de outubro de 2008.

BRASIL, 2008. INSTRUÇÃO NORMATIVA IBAMA n ${ }^{\circ} 102$, de 02 de outubro de 2008. Diário Oficial da União, nº 192, Brasília, DF, 3 de outubro de 2008.

BRASIL, 2008. LEI FEDERAL nº 11.699, de 13 de junho de 2008. Diário Oficial da União, nº 176, Brasília, DF, 15 de junho de 208.

BRASIL, 2011. INSTRUÇÃO NORMATIVA MPA nº 02, de 25 de janeiro de 2011. Diário Oficial da União, n 225, Brasília, DF, 26 de janeiro de 2011.

BRASIL, 2011. LEI FEDERAL n 10.779, de 25 de novembro de 2011. Diário Oficial da União, no 192, Brasília, DF, 26 de novembro de 2011.

BRASIL, 2012. INSTRUÇÃO NORMATIVA INTERMINISTERIAL MPA/MMA n ${ }^{\circ}$ 03, de 28 de janeiro de 2011. Diário Oficial da União, $\mathrm{n}^{\circ}$ 192, Brasília, DF, 18 de fevereiro de 2012.

BRASIL, 2012. INSTRUÇÃO NORMATIVA INTERMINISTERIAL MPA/MMA n ${ }^{\circ}$ 12, de 22 de agosto de 2012. Diário Oficial da União, nº 192, Brasília, DF, 24 de agosto de 2012 .

BRIONES, R.M., GARCIA, A.G. 2008. Poverty reduction through sustainable fisheries - emerging policy and governance issues in Southeast Asia. SEAMEO SEARCA Southeast Asian Regional Center for Graduate Study and Research in Agriculture. 183p.

BROWN, E.O., PEREZ, M.L., GARCES, L.R., RAGAZA, R.J., BASSIG, R.A., ZARAGOZA, E.C. 2010. Value chain analysis for sea cucumber in the Philippines. In: Studies and reviews 2120. Penang, Malaysia: The World Fish Center. 44p. 
BUTLER, J.R.A., GUNN, R., BERRY, H.L., WAGEY, G.A., HARDESTY, B.D., WILCOX, C. 2013. A value chain analysis of ghost nets in the Arafura Sea: Identifying trans-boundary stakeholders, intervention points and livelihood trade-offs. Journal of Environmental Management. n.123, 14-25p.

CARNEIRO, M.H., CASTRO, P.M.G., TUTUI, S.L.S., BASTOS, G.C.C. 2005. Análise das principais pescarias comerciais da região Sudeste-Sul do Brasil: dinâmica populacional das espécies em explotação. São Paulo, Instituto Oceanográfico/USP (Série documentos Revizee). 94-100p.

CASTRO, L.A.B., ARFELLI, C.A., YAMANAKA, N., SECKENDORFF, R.W. 2005. Situação atual da cadeia produtiva do pescado no litoral do Estado de São Paulo. São Paulo: Instituto de Pesca - Secretaria de Agricultura e Abastecimento. Relatório Técnico. v.2, n.21, 1-55p.

CASTRO, A.M.G., COBBE, R.V., GOEDERT, W.J. 1995. Prospecção de demandas tecnológicas: manual metodológico para o SNPA. Brasília: Embrapa/DPD. 27p.

CASTRO, A.M.G., LIMA, S.M.V., HOEFLICH, V. 1999. Curso de especialização em engenharia de produção: gestão rural e agroindustrial. Florianópolis: Ed. da UFSC: Senar, 257p.

CASTRO, A.M.G. 2001. Prospecção de cadeias produtivas e gestão da informação. Transinformação, Campinas, v.13, n.2, 55-72p.

CEASARJ - Centro de Abastecimento Alimentos Rio de Janeiro. 2014. Site http://www.ceasa.rj.gov.br/ceasa_portal/view/portal.asp. Acessado em 07 de dezembro de 2014 .

CEASAGP - Centro de Abastecimento Alimentos São Paulo. 2014. Site http://www.ceagesp.gov.br/. Acessado em 14 de dezembro de 2014.

CONNOLLY, P.L., CAFFREY, L. 2011. Supply chaining fishery advice. ICES Journal of Marine Science, v.8, n.68, 1706-1711p.

CRAWFORD, I.M. 1997. Agricultural and food marketing management. Food and Agricultural Organization of the United Nations, Rome, 261-262p. 
CRONA, B.I. 2006. Supporting and enhancing development of heterogeneous ecological knowledge among resource users in a Keny an sea scape. Ecology and Society. <http://www.ecologyandsociety.org/vol11/iss1/art32/S>. v.11, n.1. 23p.

CRONA, B., NYSTROM, M., FOLKE, C., JIDDAWI, N. 2010. Middlemen, a critical social-ecological link in coastal communities of Kenya and Zanzibar. Marine Policy, $\mathrm{n}^{\mathbf{0}}$ 34, 761-771p.

De SILVA, D.A.M., YAMAO, M. 2006. The involvement of female labor in seafood processing in Sri Lanka: impact of organizational fairness and supervisor evaluation on employee commitment. In: Proceedings of the seventh Asian Fisheries Forum, December 1-2, 2004, Penang, Malaysia: First World Symposium on Gender and Fisheries. Selangor, Malaysia, Asian Fisheries Society. 14 p.

De SILVA, D. 2011. Value chain of fish and fishery products: origin, functions and application in developed and developing country markets. FAO Value Chain Project Reports. Rome, FAO. 63 p.

DIEGUES, A.C. 1983. Pescadores camponeses trabalhadores do mar. São Paulo: Ática, São Paulo SP. 287p.

DIEGUES, A.C. 1995. Povos e Mares: leituras de sócioantropologia marítima. São Paulo: NUPAUB. Universidade de São Paulo, 265p.

DIEGUES, A.C. 2008. Marine protected areas and artisanal fisheries in Brazil. Chennai, India. International collective in Support of Fishworkers. 68p.

Di CIOMMO, R.C. 2007. Pescadoras e Pescadores: a questão da equidade de gênero em uma reserva extrativista marinha. Ambiente e Sociedade, Campinas, v.X, n.1, 151-163p.

DUBAY, K., TOKUOKA, S., GEREFFI, G. 2010. A value chain analysis of the Sinaloa, Mexico shrimp fishery. Center on Globalization, Governance \& Competitiveness. Duke University. 78p.

DURSKI, G.R. 2003. Avaliação do desempenho em cadeias de suprimentos. Ver. FAE, Curitiba, v.6, n.1, 27-38p. 
EMBRAPA - Empresa Brasileira de Pesquisa Agropecuária. 2012. Relatório técnico do Seminário Nacional de Prospecção de Demandas da Cadeia Produtiva da Pesca PROSPESQUE. Brasília, DF. 88p.

FAO - Organização das Nações Unidas para Alimentação e Agricultura. 2007. Documento técnico de pesca. Capacidad de pesca y manejo pesquero em América Latina y el Caribe. AGERO, M. (ed.), n.461. Roma, 403p.

FAO - Organização das Nações Unidas para Alimentação e Agricultura. 2010. Agricultural value chain development: Threat or opportunity for women's employment? Roma: FAO. 4p.

FAO - Organização das Nações Unidas para Alimentação e Agricultura. 2011. A Valuechain analysis of international fish trade and food security with an impact assessment of the small-scale sector. Publicado no site: <http://www.fao.org/valuechaininsmallscalefisheries/projectmethodology/en/>. Acesso em 10/04/2013.

FLOWRA, F.A., BASHAR, A.H.M.K., JAHAN, S.N., SAMAD, M.A., ISLAM, M.M. 2012. Fish marketing system and socio economic status of Aratdars in nature and Rajshahi, Bangladesh. Our Nature, n.10, 34-43p.

GALVÃO, M.C. 2013. Diálogos entre gênero, gestão e educação ambiental: os papéis das mulheres nos modos de vida na pesca artesanal. Dissertação de Mestrado. Universidade Federal do Rio Grande, Mestrado em Educação Ambiental, Rio Grande/RS. 187p.

GASALLA, M.A. 2004. Impactos da pesca industrial no ecossistema da plataforma continental interna do Sudeste do Brasil: a abordagem ecossistêmica e a integração do conhecimento. Tese de Doutorado. Instituto Oceanográfico, Universidade de São Paulo. 276p.

GASALLA, M.A., RODRIGUES, A.R., DUARTE, L.F.A., SUMAILA, U.R. 2010. A comparative multi-fleet analysis of economic indicators for fishery management in SE Brazil. Progress in Oceanography, n.87, 304-319p.

GIULIETTI, N. 1992. A pesca e a industrialização da manjuba, em Iguape, litoral sul do Estado de São Paulo. Dissertação de Mestrado. Universidade de São Paulo. 178p. 
GIULIETTI, N.; TEIXEIRA FILHO, A.R.; CARVALHO FILHO, A.C.; LOMBARDI, J.V.; CASTRO, L.A.B. de; ASSUMPÇÃO, R. 1996. Cadeia Produtiva do Pescado. São Paulo: Instituto de Pesca - Secretaria de Agricultura e Abastecimento. Relatório Técnico. 55p.

GRAÇA-LOPES, R. da; TOMÁS, A.R.G.; TUTUI, S.L. dos S.; SEVERINORODRIGUES, E.; PUZZI, A. 2002. Comparação da dinâmica de desembarques de frotas camaroeiras do Estado de São Paulo, Brasil. B. Inst. Pesca, v.2, n.28, 163-171p.

GRAÇA-LOPES, R.; SANTOS, E.P. DOS; RODRIGUES, E.S.; BRAGA, F.M.S.; PUZZI, A. 2007. Aportes ao conhecimento da biologia e pesca do camarão-sete-barbas (Xiphopenaeus kroyeri Heller, 1862) no litoral do Estado de São Paulo, Brasil. Boletim do Instituto de Pesca, São Paulo, v.1, n.33, 63-84p.

GUIMAS, M.T.D.; VERMULM JUNIOR, H.; SANTOS, L.E.; SOUZA, J.N. 1987. Estimativa da produção comercial da manjuba, Anchoviela lepidentostole (Flowler, 1911), no Rio Ribeira de Iguape, em Registro (SP). Ver. Fac. Med. Vet. Zootec. Univ. S. Paulo. v.1, n.24, 71-74p.

GUDMUNDSSON, E., ASCHE, F., NIELSEN, M. 2006. Revenue distribution through the seafood value chain. FAO Fisheries Circular $N^{\circ} 1019$. Food and Agriculture Organization of the United Nations. Rome, 51p.

HAMERI, A.P., PÁLSSON, J. 2010. Supply chain management in the fishing industry: the case of Iceland. International Journal of Logistics Research and Applications: A Leading Journal of Supply Chain Management, v.6, n.3, 137-149p.

IBAMA - INSTITUTO BRASILEIRO DO MEIO AMBIENTE E DOS RECURSOS RENOVÁVEIS. 2007. Estatística da pesca Brasil 2007. Grandes regiões e unidades da federação. Ministério do Meio Ambiente, Instituto Brasileiro do Meio Ambiente e dos Recursos Naturais Renováveis. Brasília-DF, 113p.

IBAMA - INSTITUTO BRASILEIRO DO MEIO AMBIENTE E DOS RECURSOS RENOVÁVEIS. 2014. < http://www.ibama.gov.br/institucional/recursos-pesqueiros> Acessado em 20/11/2014. 
IP - INSTITUTO DE PESCA, 2010. Defeso do camarão sete-barbas. Fonte: Centro de Comunicação do Instituto de Pesca, novembro de 2010. Site <http://www.pesca.sp.gov.br/noticia.php?id_not=7525>. Acessado em 12/01/2015.

IP - INSTITUTO DE PESCA, 2013. Informe da Produção Pesqueira Marinha e Estuarina do Estado de São Paulo, dezembro de 2012, n.26. 4p.

IP - INSTITUTO DE PESCA, 2014. Informe da Produção Pesqueira Marinha e Estuarina do Estado de São Paulo, dezembro de 2013, n.35. 4p.

IP - INSTITUTO DE PESCA, 2015. Programa de Monitoramento da Atividade Pesqueira Marinha e Estuarina do Instituto de Pesca - PMAP. < http://www.propesq.pesca.sp.gov.br/propesq/web/app.php/publico/> Acessado em 23/02/2015.

ISTIANA, KURNIAWAN, T., SAKTI, A. 2014. Entanglement fishermen with middleman (case study on fishermen of Gerbangmekar Village, Cirebon District, West Java. International Researcher, v.3, n.1. 8p.

IVO, C.T.C., FONTELES-FILHO, A.A., Da SILVA, A.C., VIEIRA, R.H.S.F. 2013. Cadeia produtiva da lagosta nas regiões Norte e Nordeste do Brasil. Fortaleza: RDS Gráfica e Editora. 218p.

KAPLINSKY, R., \& MORRIS, M. 2000. A Handbook for Value Chain Research, International Development research Center (IDRC), Canadá. 113p.

LEITE, M.C.F., 2011. O conhecimento ecológico local dos pescadores de Ubatuba, litoral norte do estado de São Paulo, como subsídio ao manejo pesqueiro com enfoque ecossistêmico. Dissertação de Mestrado, Instituto Oceanográfico da Universidade de São Paulo. 128p.

LIMA, T.A.S. 2010. Caracterização e estrutura da cadeia produtiva da sardinha no Distrito de Diogo Lopes, Macau - RN. X JORNADA DE ENSINO, PESQUISA E EXTENSÃO - JEPEX 2010 - UFRPE: Recife. 3p.

LOC, V.T.T., BUSH, S.R., SINH, L.X., KHIEM, N.T. 2010. High and low value fish chains in the Mekong Delta: challenges for livelihoods and governance. Environment, Development and Sustainability, n.12, 889-908p. 
MALDONADO, F., SANTOS, A.C. dos, 2006. Cooperativas de pescadores artesanais; uma análise sob a perspectiva teórica. Organizações Rurais \& Agroindustrias, Lavras, v.8, n.3, 323-333p.

MANESCHY, M.C. 1997. Da casa ao mar: papéis das mulheres na construção da Pesca responsável. Seminário Internacional da Pesca Responsável, em Beberibe. Ceará.

MARQUES, P.V., AGUIAR, D.R.D. 1993. Comercialização de produtos agrícolas. São Paulo. EDUSP. 295p.

MARTIN, R.V., MARTINS, R. S. 1999. Levantamento da cadeia produtiva do pescado do Reservatório de Itaipu. Artigo publicado na Revista Teor. Evid. Econ. Passo Fundo. v.7, n.13, 25-52p.

MENDONÇA, J.T. 2007. Gestão dos recursos pesqueiros do complexo estuarinolagunar de Cananéia-Iguape-Ilha Comprida, litoral sul de São Paulo, Brasil. Tese (Doutorado) - Universidade Federal de São Carlos. 383p.

MENDONÇA, J.T., LUCENA, A.C.P., 2013. Avaliação do seguro defeso concedido aos pescadores profissionais no Brasil. Série Relatórios Técnicos, São Paulo, v.1, n.50; 20-22p.

MERLIJN, A.G. 1989. The role of middlemen in small-scale fisheries: a case study of Sarawak, Malaysia. Development and Change, SAGE, London. v.20, 683-700p.

MMA MINISTÉRIO DO MEIO AMBIENTE. 2008. Instrução Normativa MMA n ${ }^{\circ}$ 189, de 23 de setembro de 2008.

MOURÃO, K.R.M., FRÉDOU, F.L., ESPÍRITO-SANTO, R.V., ALMEIDA, M.C., SILVA, B.B., FRÉDOU, T., ISSAC, V. 2009. Sistema de produção pesqueira pescada amarela - Cynoscion acoupa Lacépede (1802): Um estudo de caso no litoral nordeste do Pará - Brasil. Instituto de Pesca, São Paulo, v.3, n.35, 497-511p.

MPA - MINISTÉRIO DA PESCA E AQUICULTURA, 2014. Site <http://www.mpa.gov.br/index.php/pesca/artesanal>. Acessado em 24/03/2014.

MWIRIGI, F.M., THEURI, F.S. 2012. The challenge of value addition in the seafood value chain along the Kenyan north coast. International Journal of Business and Public Management. v.2, n.2, 51-56p. 
NEIVA, C. R. P. (cord) 2010. O mercado de pescado na região metropolitana de São Paulo. Série: o mercado do pescado nas grandes cidades latino-americanas. INFOPESCA. $88 \mathrm{p}$.

PEDROZA, C. 2012. Middlemen, informal trading and its linkages with IUU fishing activities in the port of Progreso, México. Marine Policy, . 39, 135-143p.

PHAM, T.D.T., HUANG, H.W., CHUANG, C.T. 2013. Finding a balance between economic performance and capacity efficiency for sustainable fisheries: Case of the Da Nang gillnet fishery,Vietnam. Mar. Policy, 8p.

PINHO, D.B. 1984. Cooperativas de pesca: noções fundamentais. Manual do cooperativismo - Tipologia cooperativista. $3^{\circ}$ ed. São Paulo: CNPq, v.4, 125-134p.

PLATTEAU, J.P., ABRAHAM, A. 1987. An inquiry into quasi-credit contracts: the role of reciprocal credit and interlinked deals in small-scale fishing communities. Journal of Development Studies, n.23, 461-490p.

PORTER, M.E. 1990. Vantagem competitiva: criando e sustentando um desempenho superior. Rio de Janeiro: Campus. 860p.

RODRIGUES, E.S. 1993. Aspectos biológicos e pesqueiros do camarão sete-barbas (Xiphopenaeus kroyeri) capturado pela pesca artesanal do litoral do Estado de São Paulo. Boletim do Instituto de Pesca 19 (único), 67-81p.

ROHEIM, C.A. 2008. Seafood supply chain management: methods to prevent illegally - caught product entry into the marketplace. University of Rhode Island. Kingston, USA. $23 p$.

ROSSI-WONGTCHOWKI, C.L.D.B., GODINHO, C. \& CERGOLE, M.C., 1990. Crescimento "In", BENDAZOLI, A. et al. (eds). A manjuba no Rio Ribeira do Iguape. Biologia, comportamento e avaliação de estoque. IBAMA/IOUSP/AS/SEMA. São Paulo, 15-16p.

RUSSEL, D.N. 1987. Middlemen and money lending: relations of exchange in a highland Philippine economy. Jornal Anthropol. Res, n.43, 139.161p.

RUSSELL, D., HANOOMANJEE, S. 2012. Manual on Value Chain analysis and Promotion. Project Funded by the European Union. Italy. 49p. 
SALDANHA, I.R.R. 2005. Espaços, recursos e conhecimento tradicional dos pescadores de manjuba (Anchoviella lepidentostole) em Iguape (SP). Dissertação de Mestrado. Programa de pós-graduação em Ciência Ambiental da Universidade de São Paulo. São Paulo. 181p.

SANTOS, M.A.S. 2005. A cadeia produtiva da pesca artesanal no Estado do Pará: estudo de caso no nordeste paraense. Publicado na revista: Amazônia: Ci. \& Desenv., Belém, v.1, n.1. 20p.

SEPA - Secretaria Executiva de pesca e aquicultura. 2010. I Seminário Estadual de Arranjos Produtivos Locais. Manaus.

SHAMSUDDOHA, M. 2007. Supply and Value Chain Analysis in the Marketing of Marine Dried Fish in Bangladesh and Non Tariff Measures (NTMs) in International Trading, Participatory Research and Development Initiative, House 106/7, Monipur i Para, Tejgoan, Dhaka 1215, Bangladesh. Accessed 3rd November 2010, www.prdibd.org. 11p.

SILVA, L.C. 2005. Cadeia produtiva de produtos agrícolas. Boletim Técnico. Departamento de Engenha- ria Rural. Universidade federal do Espírito Santo. 10p.

SILVANO, R.A.M., BEGOSSI, A. 2010. What can be learned from fishers? An integrated survey of fishers' local ecological knowledge and bluefish (Pomatomus saltatrix) biology on the Brazilian coast. Hydrobiologia, n.637. 3-18p.

SOUZA, K.M., ARFELLI, C.A., GRAÇA-LOPES, R. 2009. Perfil socioeconômico dos pescadores de camarão sete-barbas (Xiphopenaeus kroyeri) da praia do Perequê, Guarujá (SP). Boletim do Instituto de Pesca, São Paulo, v.4, n.35, 647- 655p.

SOUZA, K. M., ARFELLI, C. A., GRAÇA-LOPES, R., RODRIGUES da SILVA, N. J. 2011. A percepção dos integrantes da cadeia produtiva da pesca do camarão sete-barbas (Xiphopenaeus kroyeri) do Perequê (Guarujá, SP) sobre a política pública do defeso. Oceanografia e Políticas Públicas, Santos, São Paulo. 5p.

SURTIDA, A.P. 2000. Middlemen: the most maligned players in the fish distribution channel. SEAFDEC Asian Aquaculture, v.5, n.22, 26p. 
TBTI - TOO BIG, TO IGNORE, 2013. < http://toobigtoignore.net/> Acessado em 24/03/2013.

THORPE, A., BENNETT, E. 2004. Market-Driven International Supply Chains: The Case of Nile Perch from Africa's Lake Victoria. International Food and Agribusiness Management review, v.7, n.4.

TORIBIO, R. J.,GUARCÍA-del-HOYO. J. J. 2006. Evidence of market price leadership in the Spanish red seabream value chain - Implications for fisheries management. Fisheries Research, n.81, 51-59p.

TORRES, E. B., PABUAYON I. M., SALAYO, N. D. 1987. Market structure analysis of fish distribution channels supplying Metro Manila. Department of Agricultural Economics, College of Economics and Management, University of the Philippines at Los Baños, College, Laguna.

United Nations General Assembly. 2012. Fisheries and the right to food. Note by the Secretary-General, 30 October 2012 , http://www.srfood.org/images/stories/pdf/officialreports/20121030_fish_en.pdf>. Acessado em 24/03/2014.

UNEP - United Nations Environment Programme. 2009. The role of supply chains in addressing the global seafood crisis. 80p.

VALENTINI, H., D’INCAO, F., RODRIGUES, L.F., REBELO NETO, J.E., DOMIT, L.G. 1991. Análise da pesca do camarão sete-barbas (Xiphopenaeus kroyeri) na região Sudeste e Sul do Brasil. Publicado na revista Atlântica, Rio Grande, v.1, n.13, 171$177 \mathrm{p}$.

VASCONCELOS, M.; DIEGUES; A.C.S.A; SALES, R.R. 2007. Limites e possibilidades na gestão da pesca artesanal costeira. In: Costa, A. L. (Org.) Nas Redes da Pesca Artesanal. Brasília: IBAMA - MMA, 15- 83p.

VAZZOLER, A.E.A.M., 1971. Diversificação fisiológica e morfológica de Micropogon furnieri (Desmarest, 1823) ao sul de Cabo Frio, Brasil. Boletim do Instituto Oceanográfico, São Paulo, v.2, n.20, 1-71p. 
VAZZOLER, A.E.A.M., 1991. Síntese de conhecimentos sobre a biologia da corvina, Micropogonia furnieri (Desmatest, 1823), da Costa do Brasil. Publicado na revista Atlântica, Rio Grande, v.1, n.13, 55-74p.

VINH, D. T.T. 2008. Role of the middlemen in the supply of the processing industry. Case study: the central south region in Vietnan. IIFET 2008 Vietnam Proceedings. 12p.

WAMUKOTA, A., BREWER, T.D., CRONA, B. 2014. Market integration and its relation to income distribution and inequality among fishers and traders: The case of two small-scale Kenyan reef fisheries. Marine Policy, n.48, 93-101p.

WINDYANINGRUN, D., MASTRUROH, N.A. 2012. Development of the Sea Fishery Supply Chain Performance Measurement System: A Case Study. International Journal of Supply Chain Management. v.1, n.3, 20- 33p. 